INTERNATIONAL MONETARY FUND

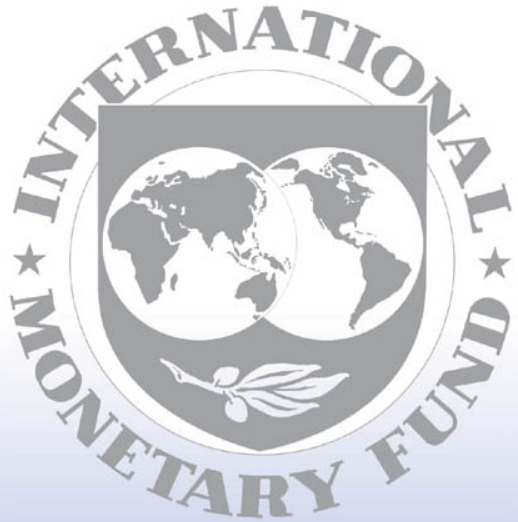

Staff

Country

Reports 


\section{Bosnia and Herzegovina: Request for Stand-By Arrangement_-Staff Report; Staff Statement; Press Release on the Executive Board Discussion; and Statement by the Executive Director for Bosnia and Herzegovina}

In the context of the request for a Stand-By Arrangement for Bosnia and Herzegovina, the following documents have been released and are included in this package:

- $\quad$ The staff report for Request for Stand-By Arrangement, prepared by a staff team of the IMF, following discussions that ended on May 5, 2009, with the officials of Bosnia and Herzegovina on economic developments and policies. Based on information available at the time of these discussions, the staff report was completed on June 17, 2009. The views expressed in the staff report are those of the staff team and do not necessarily reflect the views of the Executive Board of the IMF.

- $\quad$ A staff statement of July 8, 2009, updating information on recent developments.

- $\quad$ A Press Release summarizing the views of the Executive Board as expressed during its July 8,2009 , discussion of the staff report that completed the request.

- A statement by the Executive Director for Bosnia and Herzegovina.

The documents listed below have been or will be separately released.

Letter of Intent sent to the IMF by the authorities of Bosnia and Herzegovina* Technical Memorandum of Understanding*

*Also included in Staff Report

The policy of publication of staff reports and other documents allows for the deletion of market-sensitive information.

Copies of this report are available to the public from

International Monetary Fund • Publication Services

$70019^{\text {th }}$ Street, N.W. • Washington, D.C. 20431

Telephone: (202) 623-7430 • Telefax: (202) 623-7201

E-mail: publications@imf.org • Internet: http://www.imf.org

\section{International Monetary Fund Washington, D.C.}


This page intentionally left blank

CInternational Monetary Fund. Not for Redistribution 


\section{INTERNATIONAL MONETARY FUND}

\section{BOSNIA AND HERZEGOVINA}

\section{Request for Stand-By Arrangement}

Prepared by the European Department

(In consultation with other departments)

Approved by Poul M. Thomsen and Dominique Desruelle

June 17, 2009

Stand-By Arrangement (SBA). In the attached letter, the authorities of Bosnia and Herzegovina request a 36-month, SDR 1,014.6 million (about US\$1.6 billion, 600 percent of quota) SBA. An initial purchase of SDR 182.6 million (108 percent of quota) would be available upon approval of the arrangement, and the remainder phased thereafter, subject to quarterly reviews. In the letter, the authorities outline the economic program for which they seek Fund financial support and describe its economic policy objectives. The program's key objectives are to: (i) safeguard the currency board; (ii) consolidate public finances and bring them on a sustainable medium-term path; (iii) maintain adequate liquidity and capitalization of banks; and (iv) secure enough external financing and improve confidence. To attain these objectives, the authorities will: reduce recurrent government expenditure; reform the system of nontargeted social benefits, public administration, and the budget process, while protecting public investment and the poor; and strengthen the financial system and enhance crisis preparedness.

Discussions. During April 14-May 5, the staff team met with: (i) at the State level: Member of the Presidency Silajdžić, the Chair of the Council of Ministers Špirić, the Minister of Finance and Treasury Vrankić, and Central Bank Governor Kozarić; (ii) in the Federation of Bosnia and Herzegovina: Prime Minister Branković, Minister of Finance Bevanda, and the Prime Ministers and Finance Ministers of the ten Cantons; and (iii) in the Republika Srpska: Prime Minister Dodik and Minister of Finance Dzombić. The Fund staff also met with High Representative Inzko, ambassadors, opposition politicians, and representatives of the private sector.

Staff. The staff team comprised Mr. Christou (head); Mr. Cuc and Ms. Kinoshita (EUR); Ms. Eble and Ms. Karpowicz (FAD); and Ms. Khachatryan (SPR). Mr. Tomić, (OED) attended all policy meetings. The mission coordinated closely with World Bank staff on structural issues. 
I. Background and Recent Economic Challenges ...................................................

II. The Program .......................................................................................................... $\frac{7}{7}$

A. Overall Program Objectives and Strategy ...............................................

B. The Currency Board ................................................................................... $\underline{8}$

C. Macroeconomic Framework........................................................................ $\underline{8}$

D. Fiscal Policy .................................................................................

E. Financial Sector Policies ......................................................................... $\frac{12}{13}$

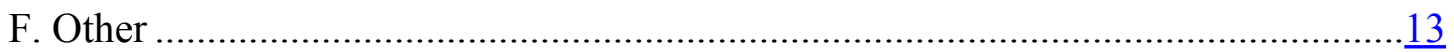

III. Program Modalities ........................................................................................ 14

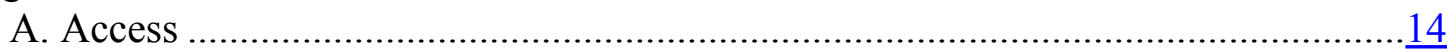

B. Capacity to Repay......................................................................................... $\frac{14}{14}$

C. Program Monitoring, Conditionality, and Safeguards Assessment.......................15

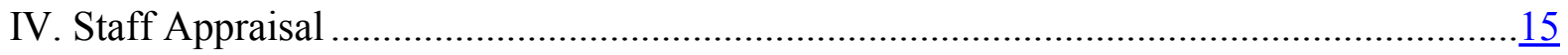

Figures

1. Indicators of Economic Activity, 2003-09 .............................................................

2. Inflation Developments, 2005-09 .......................................................................22

3. Private Sector Credit Growth .............................................................................. 23

4. Financial Sector Indicators, 2004-08 .................................................................

5. Central Bank's Foreign Assets and Commercial Banks Reserves ..................................25

6. External Trade, 2004-09 .......................................................................................... 26

7. Wage Developments, January 2005-March 2009 ......................................................27

Tables

1. Selected Economic Indicators, 2005-10 ...............................................................28

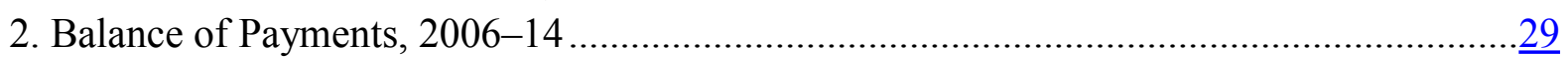

3. Selected Vulnerability Indicators, 2004-08 ….........................................................

4. General Government, 2006-14 .......................................................................

5. Elements of General Government, 2008-14 ...............................................................32

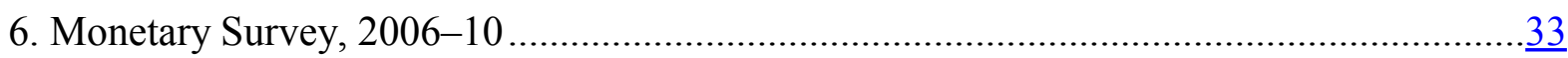

7. Monetary Authorities' Balance Sheet, 2006-10 ...........................................................34

8. Survey of Domestic Money Banks, 2006-10.............................................................35

9. Baseline Medium-Term Outlook, 2006-14 ................................................................

10. Gross Financing Requirements, 2007-14 ................................................................37

11. Indicators of Capacity to Repay the Fund, 2008-14 …...............................................

12. Financial Soundness Indicators, 2004-08.............................................................39

13. Prior Actions and Structural Benchmarks, June 2009-June 2010 ................................. $\underline{40}$

14. Proposed Schedule of Purchases Under the Stand-By Arrangement, 2009-12 ................ $\underline{41}$ 


\section{Boxes}

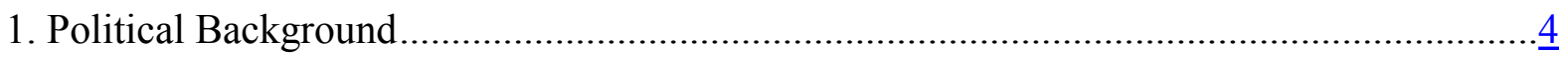

2. External Competitiveness ……………………..................................................

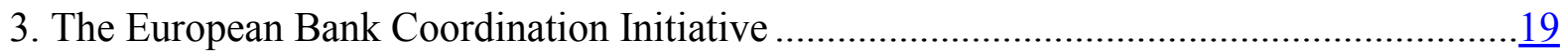

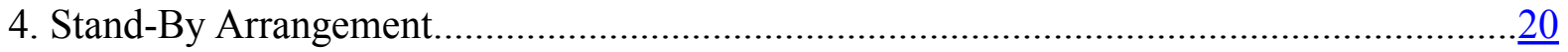

Appendices

I. Bosnia and Herzegovina: Debt Sustainability Analysis

Attachments

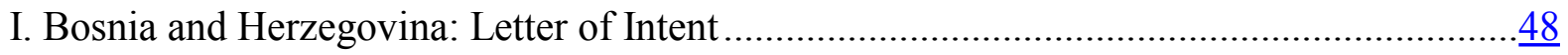

II. Technical Memorandum of Understanding ………….............................................. 


\section{BACKGROUND AND RECENT ECONOMIC CHALLENGES}

\section{Robust growth of recent years has been increasingly accompanied by}

macroeconomic imbalances. Benefiting from a favorable external environment, the currency board, and the effects of reforms in key sectors, output growth averaged 6 percent per year during 2003-08, while inflation remained low. Bank privatizations and reforms in the financial sector, along with improved growth prospects, attracted large capital inflows-FDI and long-term borrowing by foreign bank subsidiaries. The introduction of the VAT, income tax reforms, large privatizations in Republika Srpska (RS), and the establishment of the Fiscal Council strengthened public finances. All these achievements culminated in the signing of the Stabilization and Association Agreement with the EU in June 2008. However,

Bosnia \& Herzegovina: Key Macroeconomic Indicators, 2005-08

(In percent of GDP, unless otherwise indicated)

\begin{tabular}{lrrrr}
\hline & 2005 & 2006 & 2007 & $\begin{array}{c}2008 \\
\text { Est. }\end{array}$ \\
\hline Real GDP growth (percent) & 3.9 & 6.9 & 6.8 & 5.5 \\
CPI (change in percent; average) & 3.6 & 6.1 & 1.5 & 7.4 \\
Current account balance & -18.0 & -8.4 & -12.7 & -14.7 \\
General government balance & 0.8 & 2.2 & -0.1 & -4.0 \\
Reserve cover (months of imports) & 4.0 & 4.3 & 4.7 & 5.5 \\
Gross external debt & 51.3 & 47.9 & 47.5 & 44.5 \\
Public debt & 25.6 & 22.0 & 29.8 & 27.8 \\
\hline
\end{tabular}

Sources: BiH authorities; and Fund staff estimates.

with capital inflows driving a domestic demand boom, internal and external imbalances worsened recently: growth of bank credit to the private sector rose sharply, core inflation accelerated, and the current account deficit widened. Loose fiscal and incomes policies also contributed to the overheating of the economy (Figures 1 and 2). Meanwhile, economic policymaking has been complicated by a complex political setting (Box 1).

\section{Box 1. Political Background}

The Dayton Peace Agreement that ended the war in 1995 created two largely autonomous Entities: Republika Srpska and the Croat-Bosniak Federation of Bosnia and Herzegovina (Federation), itself divided into ten largely ethnic cantons, which exercise most economic power; and a State government with a limited mandate. This structure causes duplication of many domestic policy functions and weakens incentives to cooperate. In recent years, policies have been diverging between the two Entities, with the RS making steady progress on reforms and the Federation finding it difficult to mobilize action on needed reforms. Moreover, the lack of political coordination is slowing progress toward closer integration with and eventual membership in the EU. 
2. The global financial and economic crisis hit Bosnia and Herzegovina (BiH) when the overheating was already raising doubts about the sustainability of the economic expansion. The negative fallout from the global crisis started to become increasingly evident in late 2008. Stock market indices slumped, international reserves began to decline, bank credit growth came to a halt, and financial soundness indicators started to deteriorate

Bosnia and Herzegovina: Financial Soundness Indicators, 2004-08

\begin{tabular}{lrrrrr}
\hline & 2004 & 2005 & 2006 & 2007 & 2008 \\
\hline Net capital to RWA & 18.7 & 17.8 & 17.7 & 17.1 & 16.3 \\
Nonperforming loans to total loans & 6.1 & 5.3 & 4.0 & 3.0 & 3.1 \\
Return on equity & 5.8 & 6.2 & 8.5 & 8.9 & 4.3 \\
Liquid assets to total assets & 35.7 & 36.1 & 35.9 & 37.7 & 30.0 \\
Liquid assets to short- term financial liabilities & 59.5 & 61.9 & 60.8 & 61.3 & 51.8 \\
Foreign currency and indexed loans to total loans & 65.4 & 68.7 & 71.0 & 74.0 & 73.3 \\
Foreign currency liabilities to total financial liabilities & 64.0 & 64.4 & 62.8 & 65.0 & 69.5 \\
Net open position & 11.6 & 8.3 & 8.9 & 4.9 & 6.2 \\
\hline
\end{tabular}

Source: CBBH.

(Figures 3 and 4). The banking system came under strain in October 2008, as the spate of negative news about parent banks of $\mathrm{BiH}$ subsidiaries triggered a mini-run on banks. The situation stabilized quickly, with the affected banks initially receiving emergency cash from their parents, and tapping their excess reserves with the Central Bank of Bosnia and Herzegovina ( $\mathrm{CBBH})$. To counter the liquidity pressures, the $\mathrm{CBBH}$ relaxed reserve requirements in several steps (Figure 5). The situation Funding Deposit Withdrawals, October 2008-March 2009 (Cumulative, percent of GDP)

\begin{tabular}{lrrr}
\hline & Oct & Dec & March \\
\hline Decrease in deposits & 3.3 & 3.3 & 3.4 \\
Sources of funding: & & & \\
Decrease in reserves with CBBH & 2.5 & 3.0 & 3.4 \\
Increase in net fgn liabilities & 1.5 & 1.9 & 1.7 \\
Decrease in credit to private sector & -0.8 & -0.7 & -0.3 \\
Other & 0.2 & -0.8 & -1.4 \\
\hline
\end{tabular}

Decline in FX Reserves, October 2008-March 2009 (Cumulative, percent of GDP)

\begin{tabular}{lrrr}
\hline & Oct & Dec & March \\
\hline Decrease in official reserves & 1.8 & 2.2 & 3.2 \\
Counterpart & & & \\
Decrease in currency in circulation & -0.6 & -0.7 & 0.5 \\
Decrease in banks' reserves & 2.5 & 3.0 & 3.4 \\
Other & -0.1 & -0.1 & -0.6 \\
\hline
\end{tabular}
has remained stable since the October episode, but the $\mathrm{CBBH}$ lost part of its gross international reserves - by end-May, reserves were down by 16 percent relative to their peak at end-September 2008.

\section{The strong growth momentum dissipated by end-2008, inflation pressures let up,} and the trade deficit began to narrow. The squeeze came from both the domestic and external demand sides. With bank credit drying up, construction activity faltered, and a number of enterprises began to lay off workers. The worsening economic conditions in the EU pushed export growth into negative territory, and with imports dropping faster still, the trade deficit began to shrink (Figure 6). After peaking at 10 percent y-o-y in July 2008, headline inflation decelerated to zero percent y-o-y in April 2009. Core inflation also eased (from 4 percent to 1.8 percent over the same period), suggesting that spillovers from last year's large public sector wage increases may have been neutralized altogether. 


\section{With declining revenue and sharply increasing expenditure, fiscal policy}

loosened in 2008. The general government deficit widened to 4 percent of GDP from a nearbalance in 2007, with the structural balance deteriorating by 4 percentage points of GDP. Revenue performance weakened, as VAT refunds accelerated and customs duties on EU imports began to be phased out. Expenditure rose sharply, driven by increases in wages and social benefits. In the Federation, transfers to households almost doubled in nominal terms. Spending in the RS also expanded quickly as well following sharp wage increases - the RS central government's wage bill rose by about 40 percent. To this end, public sector wage increases across $\mathrm{BiH}$ have drawn attention to the large government payroll and the relatively high level of public wages compared with the rest of the economy (Figure 7).

Bosnia \& Herzegovina: General Government Operations, 2005-08 (In percent of GDP)

\begin{tabular}{lrrrr}
\hline & 2005 & 2006 & 2007 & $\begin{array}{r}2008 \\
\text { Est. }\end{array}$ \\
\hline Revenue and grants & 45.5 & 47.4 & 47.4 & 45.8 \\
Expenditure & 44.7 & 45.2 & 47.5 & 49.9 \\
Of which: current primary & 37.2 & 38.4 & 40.2 & 41.1 \\
Balance & 0.8 & 2.2 & -0.1 & -4.0 \\
Structural balance & 1.3 & 1.4 & -0.4 & -4.5 \\
Primary balance & 1.4 & 2.9 & 0.5 & -3.5 \\
\hline
\end{tabular}

Sources: BiH authorities; and Fund staff estimates.

\section{In contrast to the RS's comfortable financial position, the Federation faced a}

fiscal crisis. Receipts from the privatization of Telekom and a petroleum refining and distribution company in 2007 allowed the RS to finance its additional spending and provide subsidized lending through the Investment and Development Bank. In the Federation, the inability of the government to come to grips with large unfunded spending legislation related to benefits for war veterans and demobilized soldiers (currently absorbing a third of the Federation's budget), and the lack of progress with the privatization agenda undermined the Entity's financial health. By end-2008, the Federation's budget accumulated expenditure arrears of 1.4 percent of national GDP.

\section{The authorities have started to address the impact of the crisis, but they} recognize that there are limits to these efforts due to the severity of the downturn. In addition to measures to improve the liquidity situation in the banking sector, the deposit insurance limit was raised substantially (from KM 7,500 to KM 20,000). Moreover, in response to revenue shortfalls, Entity central governments and Cantons have begun to restrain spending. All governments recognize that financing constraints and the existing structural deficit mean that an easing of fiscal policy to cushion the downturn is unfortunately no longer possible-especially in the Federation. 


\section{The Program}

\section{A. Overall Program Objectives and Strategy}

\section{The authorities' program is designed to safeguard the currency board and} cushion the effects of the deteriorating external environment, while adopting policies to redress fiscal imbalances and strengthen the financial sector. Specifically, the program seeks to: (i) reduce the structural fiscal balance so as to limit the government's financing needs and bring public finances on a sustainable medium-term path; (ii) re-establish public wage policy restraint; (iii) support adequate liquidity and capitalization of banks; and (iv) secure enough external financing and improve confidence. If fully implemented, the program should help position BiH's economy for a strong recovery once the global economic environment improves. And, over the medium term, it would help set the stage for sustainable growth and convergence with the EU by providing a framework to launch longoverdue structural reforms to strengthen the economy's supply side, safeguard competitiveness, and ensure the stability of the currency board.

8. Against this backdrop, the program is based on strong policy measures, coupled with sizeable financial support.

- $\quad$ Continued stability of the currency board will require a strengthening of domestic policies. Following the ongoing structural fiscal deterioration, there is a need to reverse the sharp increase in public spending. To this end, cuts in recurrent expenditure along with public-sector wage restraint will ensure stability in the short term, while structural fiscal reforms will bring public finances back on the path of medium-term sustainability. Public investment is programmed to increase and the social safety net will be reformed to protect the poor. Fiscal policy measures will be accompanied by a coordinated approach to enhance financial sector stability.

- $\quad$ Large external financing support is needed to fill the external and budget financing gaps and ensure a smooth adjustment. With the Federation's public finances coming under severe financing constraints, an external financial buffer will help governments avoid crowding out domestic lending to the private sector and shore up private investor confidence. Fund resources will thus support macroeconomic policies as the economy adjusts by helping fill the fiscal financing gap and by boosting the central bank's reserves. At the same time, foreign parent banks have been encouraged to maintain their exposure to their subsidiaries in $\mathrm{BiH}$. 


\section{B. The Currency Board}

\section{The program's key objective is to ensure the stability of the Currency Board}

Arrangement (CBA). The CBA is probably among the strongest institutions in $\mathrm{BiH}$ : it has been immune to political interference, enjoys political support, and remains a key macroeconomic policy anchor. Staff's updated external stability analysis (Box 2) has found no strong evidence of a significant real exchange rate misalignment. Moreover, the financial system has some cushions to draw on, as the $\mathrm{CBBH}$ and the commercial banks have built sizeable liquidity buffers. The authorities believe that all these considerations make a compelling case for retaining the CBA at the current juncture. Nevertheless, staff emphasized that possible sizeable exchange rate depreciations in BiH's regional trading partners could have adverse implications for the CBA's viability and for the stability of the financial system. To this end, it is important to safeguard the CBA through continued political commitment, wage flexibility, prudent macroeconomic and financial sector policies, and progress in structural reform to enhance competitiveness.

\section{Macroeconomic Framework}

10. The short-term macroeconomic outlook remains challenging. The deterioration in the global environment is undermining growth through two main channels: a drop in external demand and a tightening of external financial conditions. High frequency indicators show a deterioration in the first quarter of 2009. Staff projects that growth will remain negative throughout this year with a very mild recovery only beginning in the middle of next year. With foreign parent banks merely maintaining their credit lines to their subsidiaries, credit to the economy is unlikely to increase. That, along with lower FDI and the expected

Leading indicators: Change, Percent

\begin{tabular}{lrrrl}
\hline & Ytd/ytd & y-o-y & m-o-m & \\
\hline Industrial production & & & & \\
$\quad$ Federation & -10.9 & -5.9 & 7.2 & March \\
$\quad$ RS 1/ & 13.1 & 23.8 & 16.2 & March \\
Retail trade & & & & \\
$\quad$ Federation & -11.6 & -10.4 & 13.9 & March \\
$\quad$ RS & $\ldots$ & $\ldots$ & 33.0 & March \\
Imports & -24.2 & -24.9 & 9.1 & March \\
Imports, ex food and energy & -27.4 & -27.8 & 8.9 & March \\
Exports & -21.0 & -18.6 & 4.9 & March \\
Credit to private sector & 16.6 & 13.3 & -0.3 & March \\
Broad money & 1.9 & 0.7 & -0.6 & March \\
Indirect tax revenue, gross & -8.4 & -6.6 & 15.4 & March \\
\hline
\end{tabular}

1/ Figures are affected by a startup of a large refinery in late 2008. fiscal retrenchment — on a cyclically adjusted basis — will produce a sharp drop in domestic demand, roughly equally distributed between consumption and investment. 


\section{Against this background, the program includes cautious macroeconomic projections:}

Real GDP is expected to contract by 3 percent in 2009. The contraction is projected to be higher in the Federation, where no fiscal space and tight financing conditions will not allow it to provide stimulus. The

$\mathrm{RS}$, on the other hand, with own financing available, will be able to somewhat mitigate the impact on domestic demand and growth through higher capital spending. Once confidence is restored and balance sheets begin to readjust, domestic demand is projected to slowly rebound in 2010 and output to grow moderately.

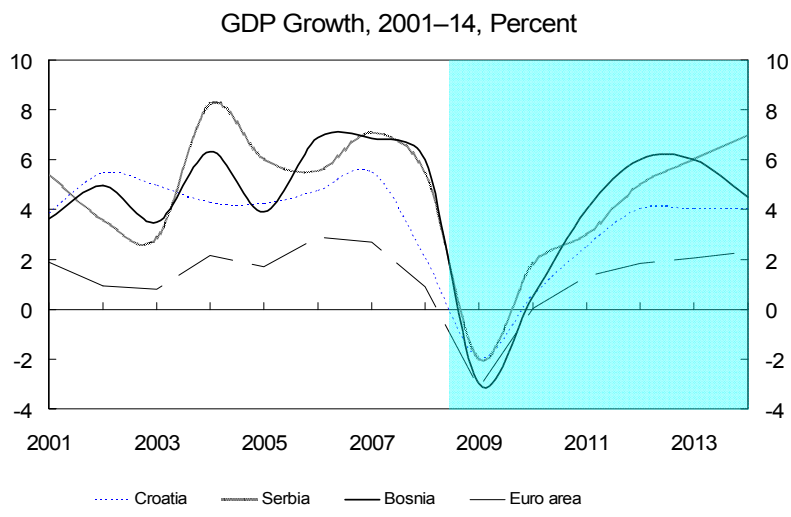

Bosnia \& Herzegovina: Key Macroeconomic Indicators, 2007-10 (In percent of GDP, unless otherwise indicated)

\begin{tabular}{lrrrr}
\hline & 2007 & 2008 & 2009 & 2010 \\
\cline { 3 - 5 } & & & Est. & Baseline Proj. \\
\hline Real GDP growth (percent) & 6.8 & 5.5 & -3.0 & 0.5 \\
CPI (change in percent; average) & 1.5 & 7.4 & 1.6 & 2.3 \\
Current account balance & -12.7 & -14.7 & -9.7 & -9.6 \\
General government balance & -0.1 & -4.0 & -4.7 & -4.0 \\
Reserve cover (months of imports) & 4.7 & 5.5 & 4.7 & 4.5 \\
Gross external debt & 47.5 & 44.5 & 52.4 & 56.7 \\
Public debt & 29.8 & 27.8 & 34.7 & 39.8 \\
\hline
\end{tabular}

Sources: BiH authorities; and Fund staff projections.

Inflation is expected to remain low in line with inflation in the euro area. The opening of a large negative output gap over 2009-10 and wage restraint will help keep core inflation low as well.

The current account deficit is projected to decline to about $93 / 4$ percent of GDP. The precipitous drop in domestic demand will help reduce the trade deficit by more than offsetting the projected worsening in the terms of trade. At the same time, some of the reduction in the trade deficit will be offset by a fall in

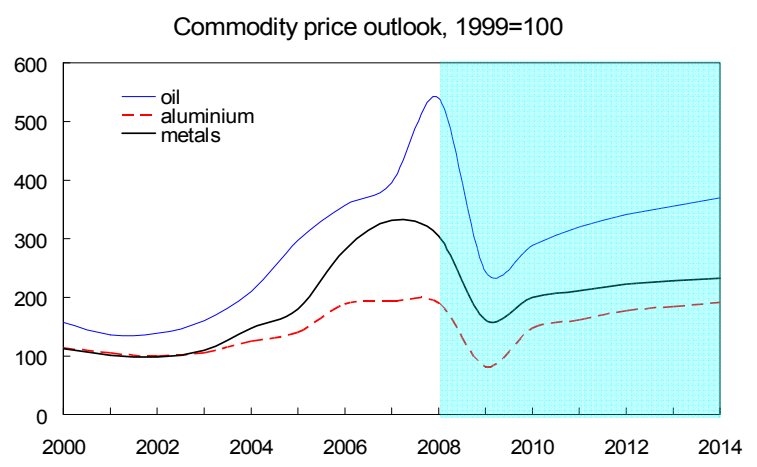
remittances. The sharp contraction in 
the current account deficit over 2009-10 and the continued drop in subsequent years will bring it to a level considered sustainable over the medium term. Moreover, external competitiveness is projected to remain adequate with wage policy marked by restraint and progress on structural reforms.

The balance in the capital and financial account is projected to fall from a surplus of $€ 1,530$ million in 2008 to a $€ 477$ million surplus in 2009. Program assumptions for 2009-10 include: (i) foreign parent banks maintaining their exposure to $\mathrm{BiH}$ (thus a 100 percent rollover); (ii) zero net trade credit in 2009 and only a mild recovery in 2010; (iii) a halving of FDI in 2009 from the 2008 level, followed by a recovery in 2010 , in line with commitments already in the pipeline; (iv) no privatization proceeds; and (v) a reduction in the net liability position of corporates.

\section{While there are upside risks to the baseline, the balance of risks is tilted}

somewhat to the downside. In the near term, output could be further compressed if the drop in external demand and the slowdown in capital inflows are larger than anticipated. Also, a bigger-than-envisaged credit crunch could cause a sharper contraction in domestic demand and thus a faster external adjustment. On the upside, stronger FDI, higher grants, and the economic stimulus measures in the RS could mitigate the decline in domestic demand. Moreover, measures to strengthen the financial sector and envisaged EBRD and World Bank support to banks and SMEs, respectively, could accelerate the recovery in the provision of credit.

\section{The program projects a gradual economic recovery over the medium term.}

Easing of global deleveraging pressures should cause external financing to resume, which along with improving growth prospects should lead to a resumption of lending. Higher FDI, along with privatization in the Federation, will boost investment. Moreover, wage restraint, fiscal policy crowding in the private sector through medium-term fiscal consolidation, and ambitious structural reforms will deliver strong productivity gains, a gradual improvement in competitiveness, and better growth prospects.

\section{Fiscal Policy}

\section{The sharp deterioration in the structural fiscal balance and tight financing} constraints do not leave room for counter-cyclical fiscal policy. The general government is starting with a sizeable structural imbalance (4 $1 \frac{1}{2}$ percent of GDP in 2008) and, under current policies, the headline deficit would widen to $73 / 4$ percent of GDP thus implying an additional $1 \frac{1}{2}$ percentage points of GDP deterioration in the structural balance. Without a policy correction, the deficit would spiral over the medium term, thus worsening fiscal sustainability prospects. In addition, financing conditions have also deteriorated. Although the RS could meet its financing needs by tapping its privatization funds, the Federation government would be left unable to finance a large deficit at a reasonable cost. 


\section{Against this backdrop, the proposed program envisages a gradual fiscal}

adjustment (LOI, $\uparrow 14)$. The requested financing from the Fund will support a smooth return of fiscal policy back to the target path implied by a balance at full potential output by $2012-13$. To this end, the fiscal targets of 43/4 percent of GDP in 2009 and 4 percent in 2010 strike a compromise between: (i) the need to reduce the structural balance and restore fiscal viability over the medium term; (ii) tight financing constraints, especially in the Federation; and (iii) the desire to crowd in the private sector. The composition of the adjustment between the entities reflects the need to reverse recent expenditure trends and tight financing constraints in the Federation. The adjustment by the State provides a strong signal for burden-sharing and public wage policy restraint. Finally, aware of the risks to the budget, the authorities stand ready to take compensatory measures, if needed, focusing mainly on the expenditure side.

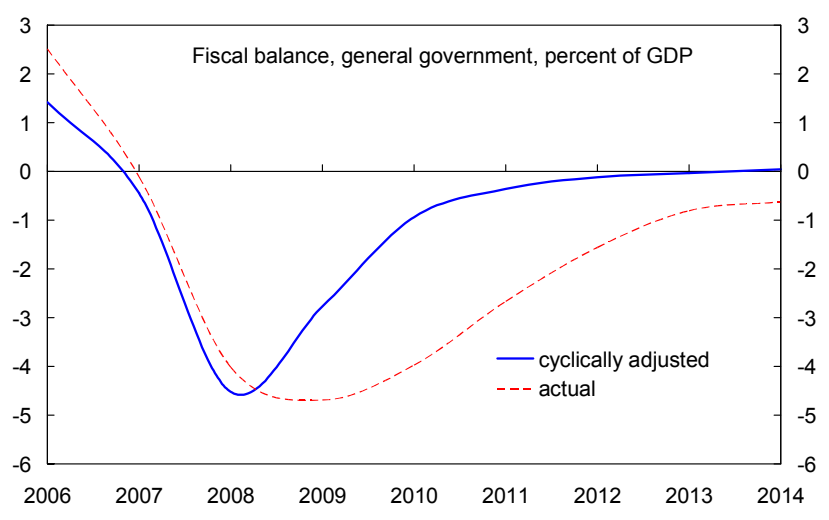

Bosnia \& Herzegovina: Fiscal Balance, 2008-10 (In percent of GDP)

\begin{tabular}{lrrrr}
\hline & 2008 & \multicolumn{2}{c}{2009} & 2010 \\
\cline { 3 - 4 } & & \multicolumn{2}{c}{ No } & \\
& Est. & measures & Prog. & Prog. \\
\hline General government & -4.0 & -7.8 & -4.7 & -4.0 \\
State & 0.1 & -0.4 & -0.3 & -0.5 \\
Federation & -1.3 & -4.4 & -2.2 & -1.7 \\
Republika Srpska & -1.4 & -3.1 & -2.2 & -1.8 \\
Brcko District & 0.2 & 0.0 & 0.0 & 0.0 \\
ITA/float/other & -1.7 & $\ldots$ & $\ldots$ & $\ldots$ \\
\hline
\end{tabular}

Sources: BiH authorities; and Fund staff estimates.

16. The program focuses on measures to reduce recurrent spending and to strengthen revenue (LOI, $₫ 16$ and 17)

Specifically: (i) the State will reduce the wage bill and spending on goods and services;

(ii) the Federation, through an Emergency Law, will reduce the wage bill, transfers, and other recurrent expenditure; and

(iii) Republika Srpska will reduce the wage bill, transfers to individuals, and other recurrent spending. All these measures will be adopted and included in rebalanced budgets that will be submitted to the Entity Parliaments prior to Board consideration of the SBA. Finally, on the revenue side, increases in excises on tobacco, coffee, and
Proposed fiscal measures for 2009

\begin{tabular}{lrr}
\hline & KM million & \% of GDP \\
\hline Revenue measures & & \\
Increases in excises & 162 & 0.7 \\
Expenditure measures & 603 & 2.5 \\
Wages & 206 & 0.8 \\
State & 31 & 0.1 \\
Federation & 152 & 0.6 \\
RS & 22 & 0.1 \\
Goods and services; other current & 230 & 0.9 \\
State & 9 & 0.0 \\
Federation & 150 & 0.6 \\
RS & 71 & 0.3 \\
Transfers to non-public agents & 164 & 0.7 \\
Federation & 111 & 0.5 \\
RS & 53 & 0.2 \\
Total 1/ & 765 & 3.1 \\
State & 40 & 0.2 \\
Federation & 518 & 2.1 \\
RS & 198 & 0.8 \\
\hline I/ Includes measures of KM9 million for Brcko district. &
\end{tabular}


petroleum products in line with commitments toward the EU aim at offsetting some of customs revenue loss. The full-year impact of these measures will also contribute to further fiscal consolidation in 2010.

\section{The Entity governments are committed to safeguard public investment and to} protect vulnerable groups. Capital spending is projected to increase from 6 percent of GDP in 2008 to 7 percent in 2009, while efforts will be made to improve the rate of absorption of EBRD and EIB funds for infrastructure, thus providing for stronger growth potential over the medium term. Moreover, the authorities are committed to cushion the effects of the fiscal adjustment and of the reforms of benefits system, by reforming the social safety net and thus protecting the poor (LOI, $\mid 20-21$ ). To this end, a Development Policy Lending operation currently being discussed with the World Bank includes two components that focus on enhancing safety net design and the eligibility process, and providing income support and job creation to vulnerable unemployed persons.

\section{To put fiscal sustainability on a permanent footing, the authorities have} proposed a series of structural fiscal reforms to improve public finance management and contain key expenditure pressures (LOI, $\uparrow 20$ ). To this end: (i) the operational framework of the Fiscal Council will be strengthened, and the Council will take a lead role in the preparation of the 2010 budgets; (ii) the Federation, in consultation with the World Bank, will undertake a comprehensive reform of its rights-based benefits system with the objective of rationalizing and streamlining those benefits and improving targeting; (iii) steps will be taken by all governments to reform public administration and improve its efficiency; and (iv) the Federation government will adopt a comprehensive wage law, aimed at improving transparency by consolidating all allowances into the base wage. Finally, the Federation government is determined to move ahead with the privatization of state-owned companies.

\section{E. Financial Sector Policies}

19. BiH's banking system has been resilient, but stresses are building up. As noted above, financial soundness indicators, although still healthy, have began to point to unfavorable trends, particularly in profitability, and the large volume of forex-linked lending raises the possibility of currency mismatches in household and corporate sectors. Stress tests conducted by an MCM TA mission in April 2009 indicate that the banking sector is generally resilient to various types of mild shocks. However, it is vulnerable to: (i) a large increase in nonperforming loans; (ii) a large shock in funding costs; (iii) the indirect effect of a large depreciation; and (iv) a deposit run. Aware of these vulnerabilities, over the next few months, the authorities will strengthen their capacity to conduct stress tests by improving data collection, the methodology, and the frequency of testing.

\section{Financial sector policies will focus on enhancing the capability of monitoring} financial stability. To this end, a Standing Committee for Financial Stability (SCFS) will be established comprising of representatives of the Fiscal Council, the CBBH, the two banking agencies, and the Deposit Insurance Agency (DIA). As a first step, the Committee will 
approve and sign a Memorandum of Understanding (MoU) to formalize the cooperative arrangements for financial stability, crisis preparedness and management. Moreover, the $\mathrm{CBBH}$ and the two banking agencies will monitor high-frequency data, and on the basis of such data prepare regular reports for the SCFS.

\section{The authorities will improve the crisis management framework by strengthening} the bank resolution and deposit insurance frameworks (LOI, $\uparrow 24$ and 25). Specifically, they will prepare a contingency manual for a two-agency bank resolution strategy, make law amendments to broaden the banking supervisory agencies' discretion to appoint a temporary administrator, and ensure irreversibility of supervisors' decisions and seniority of the DIA's claims for depositor reimbursements over the claims of general creditors. To ensure continued confidence in the deposit insurance scheme, the authorities plan to bring the coverage more closely in line with neighboring countries and prospective requirements under EU directives. To this end, the deposit insurance funding will be strengthened by a contingent credit line negotiated with the EBRD.

\section{Foreign banks' commitment to maintain exposures and to enhance capital if} needed is a key element in improving financial stability. The BiH banking system is dominated by foreign-owned banks (accounting for 95 percent of total assets) whose parents are mostly in the euro area. The worsening of the global financial situation necessitates coordinated action, including support of parent banks and home country authorities. The authorities have thus sought pledges from foreign banks to maintain exposure to their $\mathrm{BiH}$ subsidiaries and to recapitalize those as needed over the program period (Box 3).

\section{F. Other}

23. The authorities and staff agreed on the need to improve the quality of statistics so as to strengthen policy analysis and program monitoring (LOI, $\mid 26-28)$. Specifically, the State and Entity Statistics Agencies will further harmonize the expenditure- and production-side GDP data and publish it in a timely manner, while the latter two Agencies will develop quarterly and/or semiannual GDP data. Strong efforts will be made to compile fiscal data harmonized with Eurostat and the IMF's Government Finance Statistics guidelines. The authorities also intend to improve the coverage of fiscal statistics and to ensure timely submission of fiscal data by lower levels of government in the two entities. To this end, and under the umbrella of the Fiscal Council, a coordinating group will be set up, with the task of collecting and consolidating fiscal statistics from all levels of government in $\mathrm{BiH}$. Finally, improvements will be made on the coverage and methodology of statistics on foreign grants. 


\section{Program Modalities}

\section{A. Access}

\section{BiH faces large balance of payments financing needs over the next three years.}

Under the program's rollover assumptions and maintenance of official foreign exchange reserves at the end-May 2009 level, gross financing needs of $€ 1,411$ million in 2009 will produce a financing gap of approximately $€ 433$ million. For 2010 , a strong adjustment program will reduce the budget's financing needs substantially, thus allowing to maintain reserves to the equivalent of 4.5 months of prospective imports of goods and services. With the current account continuing to adjust and rollover rates and FDI improving due to enhanced confidence in economic policies and the projected recovery in the world economy, gross financing needs during 2011 and the first half of 2012 are projected to decline substantially. The total financing gap under the program would amount to $€ 1,488$ million, with commitments from the World Bank of $€ 189$ million and indications for support from the EU of $€ 100$ million filling some of the gap. Filling the remainder of the gap will require about $€ 1,145$ million ( 600 percent of quota) from the Fund during the program period.

\section{B. Capacity to Repay}

25. BiH's capacity to repay the Fund is expected to be good. Its excellent record of serving its Fund obligations, the expectation that the program would lay the foundations for the return to a sustainable medium-term growth path, and a strong political commitment to the Fund-supported program provide assurances that $\mathrm{BiH}$ will be able to discharge its Fund obligations in a timely manner. By the end of the SBA, Fund credit outstanding is projected to be 7.5 percent of GDP (31.8 percent of gross reserves).

\section{Notwithstanding the strength of the authorities' commitment, this program}

entails significant risks. These risks pertain to domestic policy implementation and the global economic environment. While policymakers at all levels agreed on the need for a comprehensive program to deal with the crisis, and the Fiscal Council signed off on the program, political developments over the coming months could test their commitment to the program. If adjustment is incomplete, higher balance-of-payments and fiscal disequilibria could lead to capital outflows and raise risks to BiH's ability to repay the Fund. As for the global environment, a deeper and more prolonged global recession could lower trade and capital flows more sharply than projected in the program scenario. And, if global financing conditions do not improve, financing needs may be higher, thus highlighting the need to be ready to adjust the program as needed. Moreover, a loss of depositor confidence could trigger a deposit run, increase pressures on the currency board, and lead to a deeper and more prolonged recession. While the CBA enjoys strong political and public support, the needed multi-year policy adjustment could prove controversial, and it could thus test the governments' political commitment. It is possible that foreign banks will be unable to maintain their exposure to $\mathrm{BiH}$, given the regional dimensions of the financial sector crisis 
and of their operations. The authorities recognize all these risks and stand ready to adjust their policies as circumstances change.

\section{The program's design aims at mitigating some of the above risks to the Fund.}

Approval of the key fiscal adjustment measures by the State and the Entities needed to bring the 2009 fiscal deficit down and re-balanced Entity budgets by governments are prior actions for Board consideration of the request for the program. In addition, parliamentary approval of the fiscal measures and re-balanced budgets for 2009 will be obtained by the time of the first review of the SBA. To achieve sustained lower fiscal deficits, the program includes structural benchmarks on adopting a reform plan for rights-based benefits (Federation), on prohibiting passage of unfunded legislation (Federation), and on fiscal reporting. For the financial sector, structural benchmarks include the establishment of a standing committee of financial stability and signing of the MoU on financial stability and crisis management.

\section{Program Monitoring, Conditionality, and Safeguards Assessment}

28. The SBA will run over 36 months from July 2009 to June 2012 (Box 4). The size and timing of the disbursements should ensure that the program is able to support BiH's economic policies during the current period of global deleveraging. Given the high level of access and uncertainty surrounding the projections under the program, the authorities will consult with staff on evolving risks and agree on policy adjustments needed to achieve the program's goals.

29. Program performance will be monitored by quarterly reviews. The first review under the program will be based on end-September 2009 targets and the second review on end-December 2009 targets. Structural conditionality is consistent with the program's focus on the fiscal and financial sectors (Table 13). The quantitative performance criteria, benchmarks, and prior actions are indicated in Tables 1 and 2 of the Letter of Intent.

30. Staff has initiated an update safeguards assessment of the CBBH, which needs to be completed no later than by the first review under the SBA. This assessment will update the assessment completed in January 2005, which made recommendations to address weakness identified in the CBBH's safeguards. Based on the information received from the authorities all of these recommendations have been implemented. Staff has requested from the authorities the documentation necessary to complete the update assessment and will hold initial discussions with the central bank's external auditors.

\section{Staff Appraisal}

31. Bosnia and Herzegovina faces a difficult economic situation. The recent global economic and financial crisis has hit the economy hard at a time when macroeconomic imbalances were already evident. With capital inflows driving a domestic demand boom, credit expanded sharply, core inflation accelerated, and the current account deficit widened. Looser fiscal and incomes policies in 2008 further exacerbated these imbalances, limiting the 
space for maneuver when the crisis hit. Since the onset of the global crisis, net capital inflows dried up, exports and imports plunged, international reserves began to decline, and budget revenues tumbled. Staff welcome the authorities' steps to address the impact of the crisis, although their efforts are dwarfed by the severity of the downturn.

\section{At this critical juncture, the return to fiscal and external sustainability through} an orderly macroeconomic adjustment hinges on the adoption of appropriate policies and adequate financing. The authorities' program centers on safeguarding the currency board — which enjoys broad political support and has served the country well—and cushioning the effects of the deteriorating external environment. Staff support this approach which will address fiscal imbalances, strengthen the financial sector, and facilitate a return to sustainable economic growth and thus improve living standards.

\section{Strong domestic policies will be required for this strategy to be successful. The} program envisages a speedy return to the fiscal consolidation path, structural fiscal reforms, and measures to strengthen the financial system and enhance crisis preparedness. Staff believe that this policy package addresses the areas of BiH's main vulnerabilities and should therefore contribute to enhanced market confidence. Public spending and wage restraint will also help improve competitiveness, support external adjustment, and bring the current account to a sustainable range. However, implementation of these policies will be challenging and calls for broad political support. To this end, the authorities will need to communicate the benefits of this approach and engage the public on the importance of reforms.

\section{The fiscal policy package strikes a balance between the need for fiscal} adjustment and the desire to adopt reforms to ensure medium-term sustainability. The authorities' plans envisage a substantial improvement in the structural balance between 2009 and 2011. Thus, the need to support the currency board and bring public finances to a sustainable path does not allow automatic stabilizers to work in full. The fiscal adjustment focuses on recurrent expenditure cuts that reverse sharp recent increases, to be supported by structural fiscal reforms, most importantly of the system of nontargeted social benefits, public administration, and public finance management. In this regard, staff welcome that the program ensures that public investment will increase and that the social safety net will be reformed to protect vulnerable groups. While the short-term expenditure cuts and the reforms to the system of benefits are likely to be difficult, staff agree that they have important longterm benefits.

\section{The authorities' comprehensive financial sector strategy aims at strengthening} the banking sector and improving crisis preparedness. Staff support the authorities' plans to enhance the monitoring of financial stability by establishing a standing committee in charge of crisis prevention and management, and by signing a formal memorandum of understanding on cooperation. The crisis management framework also needs to be improved by strengthening the bank resolution and deposit insurance frameworks, while the capacity to 
conduct stress tests be enhanced. Finally, by seeking to secure commitments by the main foreign parent banks to maintain exposures to their $\mathrm{BiH}$ subsidiaries and to capitalize them as needed, the program helps contain external financing gaps and ease the impact of the global crisis. Although all these steps are welcome, staff urge the supervisory authorities to remain vigilant and proactive.

36. Yet considerable risks remain. The political support for key fiscal reforms may fade and the economic deterioration may be more serious. Also, while the currency board enjoys broad political and public support, the needed multi-year adjustment may challenge the political commitment by all governments, and its strength could be tested in the case of sizeable exchange rate depreciations in BiH's regional trading partners. To minimize risks, the program includes strong safeguards, namely approval of key fiscal measures and of rebalanced budgets prior to Board consideration of the request for the program. Moreover, staff take note of the commitment by the authorities at all levels to strongly support implementation of the program and to adjust policies as circumstances change. In view of this, staff support the authorities' request for a 36-month Stand-By Arrangement. 


\section{Box 2. External Competitiveness}

\section{An updated analysis finds no strong evidence of a misaligned real exchange rate (RER) at present that could result in future external instability. However, the estimates are subject to large uncertainties.}

The CGER macroeconomic balance approach suggests an equilibrium current account deficit (CAD) of 7.4 percent of GDP after taking into account about 1.8 percent of GDP capital transfers. The external sustainability approach also suggests the same level of equilibrium CAD. Once we account for rapid financial deepening and integration that are notable particularly in Europe (Abiad, Leigh, and Mody (ALM), 2007), however, the equilibrium CAD is estimated at 11.7 percent of GDP.

The estimates from the adjusted CA gap point to no strong evidence of a misaligned RER at present. Depending on the methodology, estimates range from a slight overvaluation of $4 \frac{1}{2}$ percent to undervaluation of 17 percent. One should caution, though, that these estimates are subject to large uncertainties due to the large forecast errors of regression-based estimates, and other assumptions regarding BiH's business cycle, the import and export elasticities, and RER movements.

Current Account Gap and Estimated Real Exchange Rate Misalignment

\begin{tabular}{lcccc}
\hline & $\begin{array}{c}\text { CGER } \\
\text { Macrobalance } \\
\text { approach }\end{array}$ & $\begin{array}{c}\text { ALM (2007) } \\
\text { Macrobalance } \\
\text { approach 1/ }\end{array}$ & $\begin{array}{c}\text { External } \\
\text { Sustainability } \\
\text { Approach }\end{array}$ & $\begin{array}{c}\text { CGER Equilibrium } \\
\text { real exchange rate }\end{array}$ \\
\hline Equilibrium CA balance & -5.6 & -9.9 & -5.6 & n.a. \\
Capital transfers & -1.8 & -1.8 & -1.8 & n.a. \\
Adjusted equilibrium CA balance (i) & -7.4 & -11.7 & -7.4 & n.a. \\
Underlying CA balance (ii) & -8.3 & -8.3 & -8.3 & n.a. \\
CA gap (i)-(ii) & 0.9 & -3.4 & 0.9 & n.a. \\
Implied over(+)/under(-) valuation & 4.3 & -17.1 & 4.6 & -16.9 \\
\hline
\end{tabular}

Source: Staff estimates.

1/ Abiad, Leigh and Mody (2007)"International Finance and Income Convergence: Europe is Different"(IMFWP/07/64)

Export trends suggest that competitiveness remains adequate: the value of goods exports grew at an average 20 percent per year during 2000-08, and $\mathrm{BiH}$ has being gaining market share in EU markets. Also, the CPI-based real effective exchange rate has been stable during the same period. Finally, relative to nontradables, average labor productivity growth of $\mathrm{BiH}$ tradables has been much higher than that of the main trading partners.
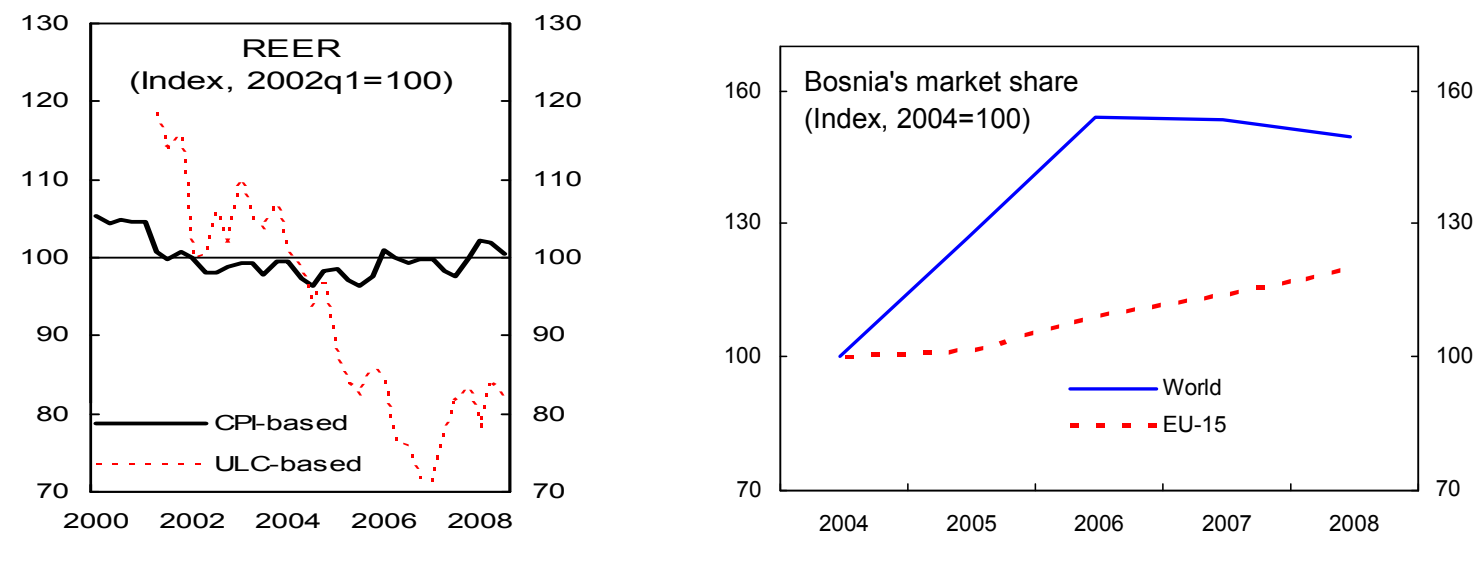


\section{Box 3. The European Bank Coordination Initiative}

The banking system in $\mathrm{BiH}$ is dominated by subsidiaries of foreign-owned banks (mainly from Austria, Italy, and Slovenia). Being the primary source of credit growth in recent years, those banks have been instrumental in BiH's strong economic performance. Moreover, foreign parent banks have a declared long-term interest in $\mathrm{BiH}$ as well as in the region. However, uncertainty about other banks' strategies may tempt risk-averse agents to cut back on lending or abandon the region. Coordination of continued foreign parent bank commitments for rollover and capital is therefore crucial for financial stability as well as for balance of payments sustainability.

To secure the support from parent banks, a meeting is scheduled to take place in Vienna on June 22, 2009. The meeting will be hosted by the Joint Vienna Institute and chaired by the Fund. It will include six largest foreign bank groups incorporated in $\mathrm{BiH}$, their parent banks, the European Commission, the World Bank group, the EBRD, the $\mathrm{EIB}$, the $\mathrm{BiH}$ authorities, and representatives of the home country authorities.

After a discussion on the current economic situation of $\mathrm{BiH}$ and the authorities' program, commitments will be sought from foreign parent banks to maintain their exposure to their subsidiaries in $\mathrm{BiH}$ and to recapitalize them as needed. 


\section{Box 4. Stand-By Arrangement}

Access: SDR 1,014.6 million, 600 percent of quota.

Length: 36 months.

Phasing: SDR182.6 million will be made available upon the Board's approval of the arrangement to address fiscal and balance of payment needs during the rest of the year. The eleven subsequent quarterly tranches, starting from December 2009 and ending in June 2012, will equal SDR 832 million.

\section{Conditionality}

\section{Quantitative Performance Criteria}

- Ceiling on accumulation of net credit of the banking system to:

$\checkmark$ the general government

$\checkmark$ the State government

$\checkmark$ the RS government

$\checkmark$ the Federation government

- Ceiling on new guarantees and the assumption of enterprise debt to banks by the State, Federation, and RS governments

- Ceiling on accumulation of external payment arrears

- Ceiling on contracting new short-term external nonconcessional debt

- Ceiling on accumulation of domestic arrears of:

$\checkmark$ the State government

$\checkmark$ the RS Government

$\checkmark$ the Federation government

\section{Prior Actions for Board consideration of the program request}

- Adopt rebalanced budgets by Entity governments and submit to Parliament

- Adopt amendments to the wage bill legislation by the Council of Ministers

- Adopt the Intervention law in the Federation.

- Adopt a new Excises Law

- Adopt the Global Framework by the Fiscal Council

\section{Structural Benchmarks}

- Adhere to the Currency Board Arrangement as constituted under the law (Continuous)

- Approve the rebalanced budgets by the Entity Parliaments (End-August 2009)

- Agree on an action plan acceptable to the World Bank and IMF staffs to reform the system of rights-based transfers in the Federation (end-November 2009)

- Submit to the Federation Parliament a Law forbidding passing of unfunded legislation (endNovember 2009)

- Publish on the State government's web site quarterly consolidated general government accounts with a 5 week lag (Continuous)

- Form a standing committee of financial stability and sign the MoU on financial stability, crisis preparedness and crisis management (end-November 2009)

- The Deposit Insurance Agency to impose a principle of universal membership requirements, including for partially state-owned banks (end-February 2010). 
Figure 1. Bosnia and Herzegovina: Indicators of Economic Activity, 2003-09
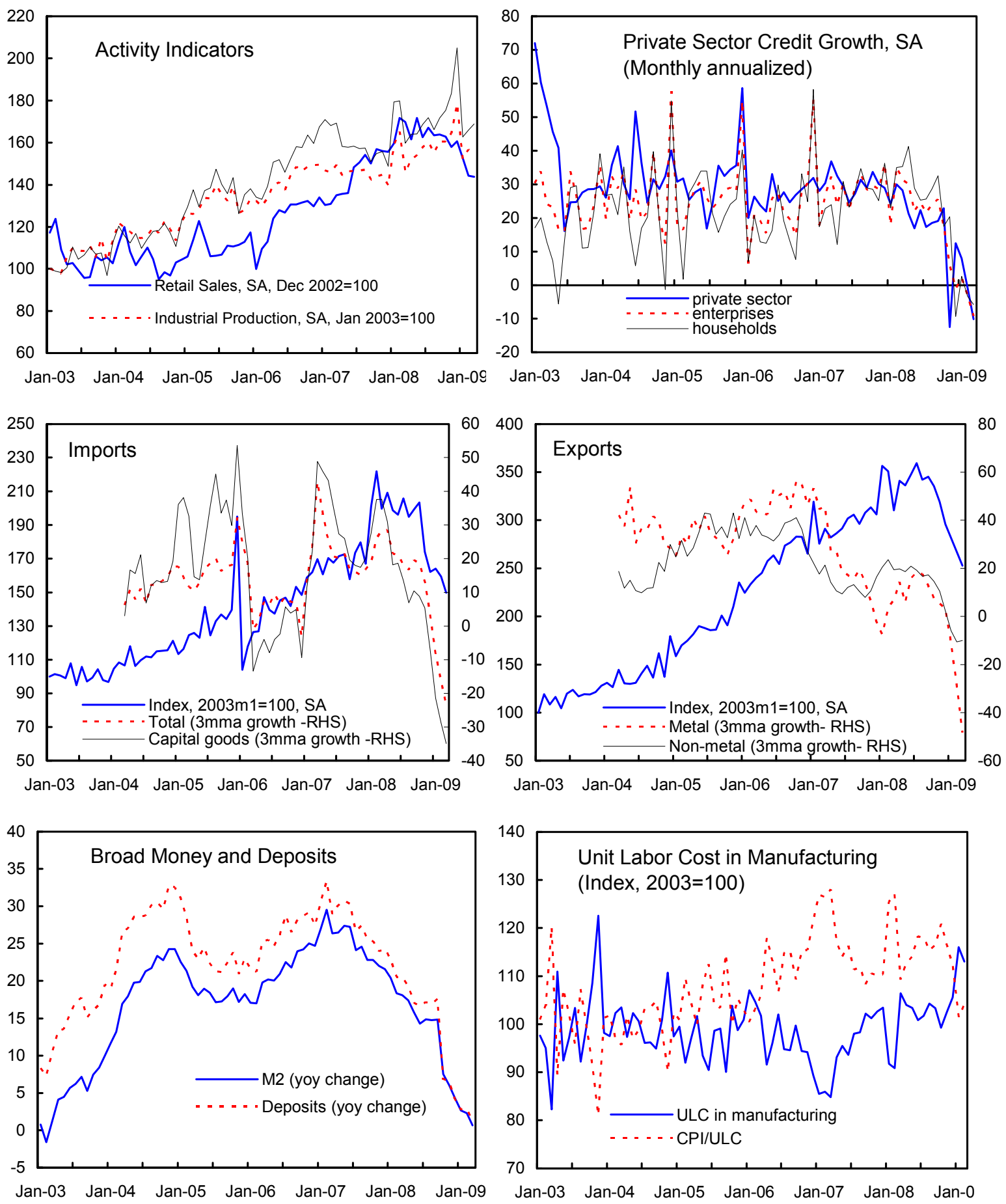

Sources: Bosnian authorities; and IMF staff estimates. 
Figure 2. Bosnia and Herzegovina: Inflation Developments, 2005-09
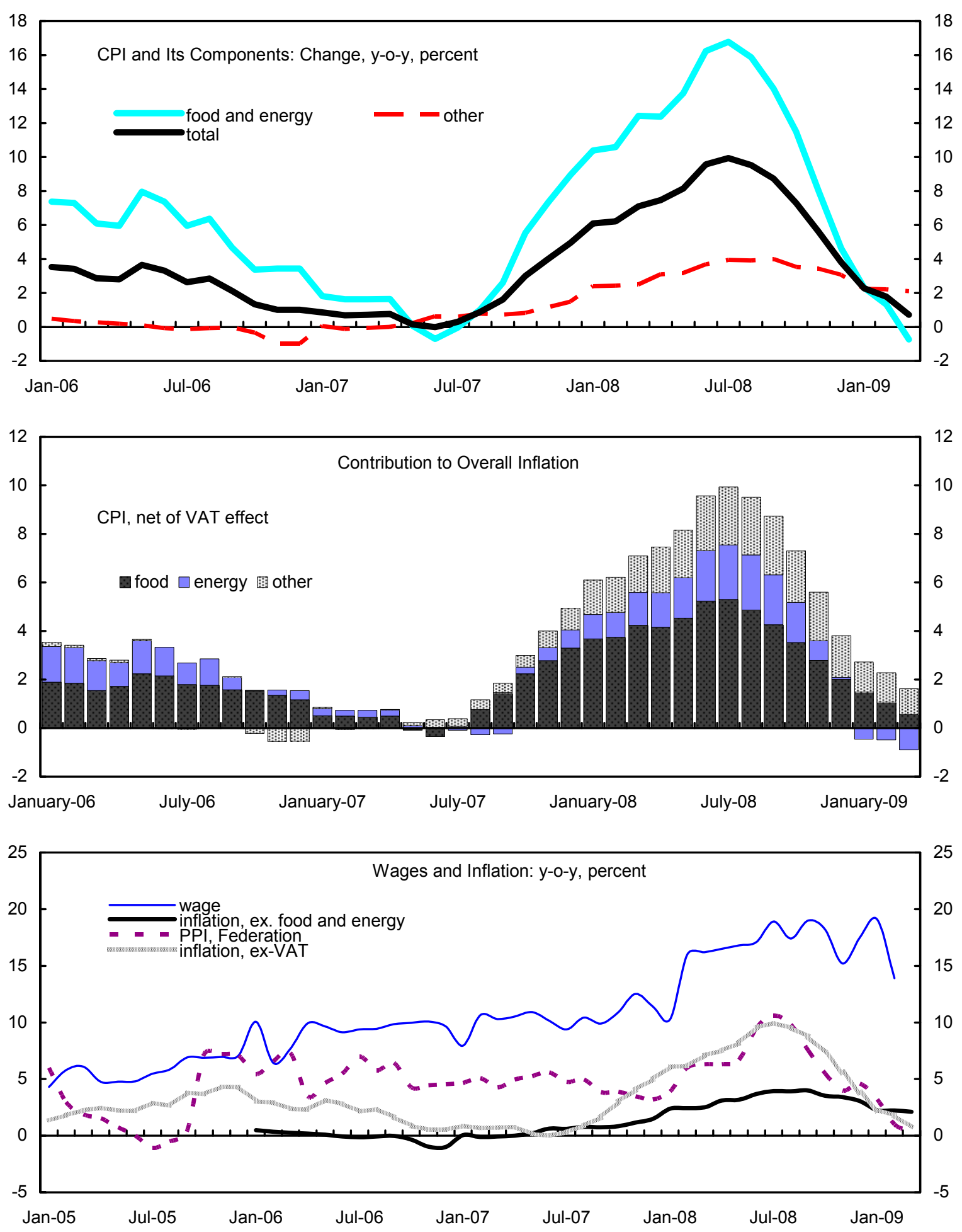

Sources: BiH authorities; and IMF staff calculations. 
Figure 3. Bosnia and Herzegovina: Private Sector Credit Growth, December 2006-March 2009, Percent
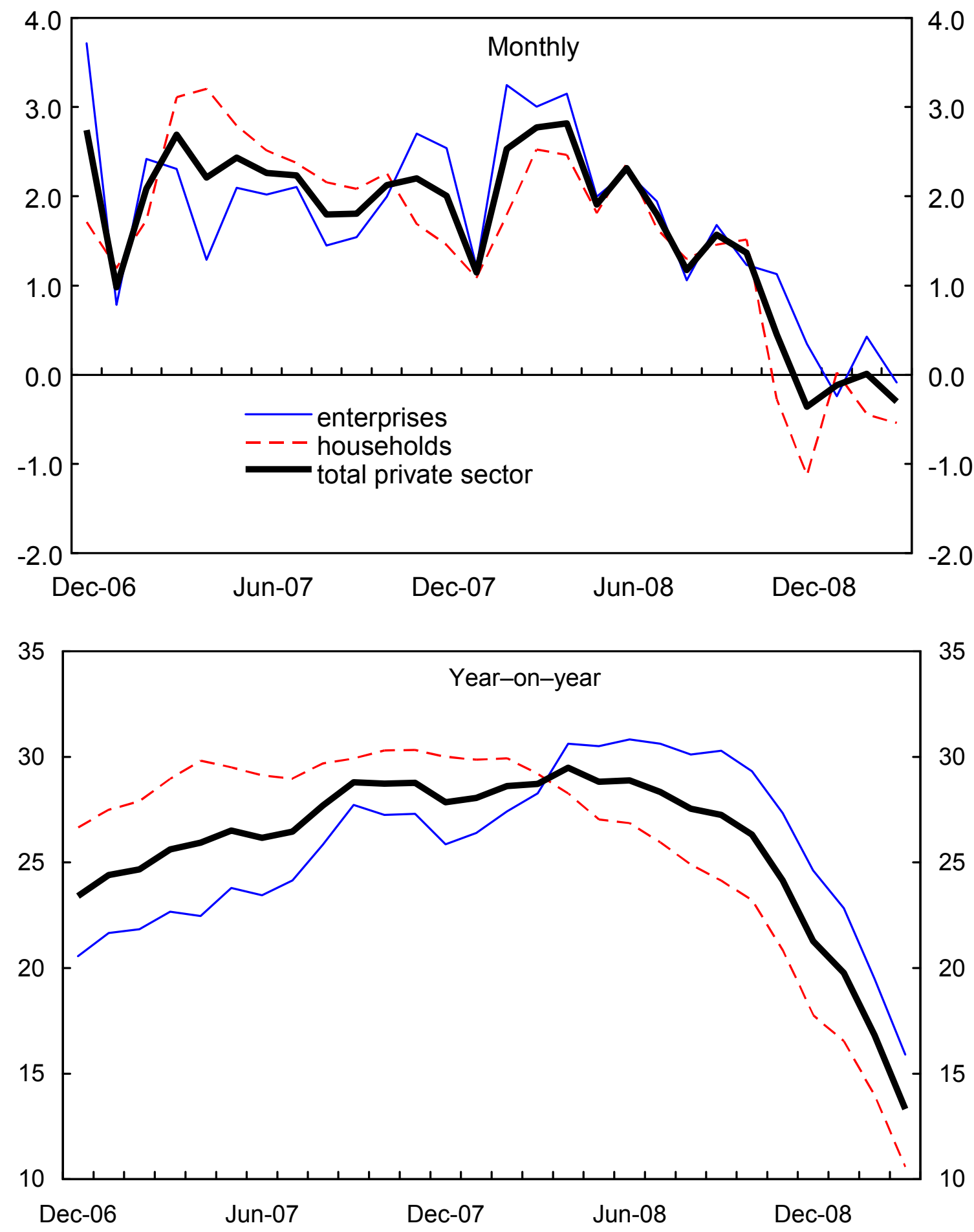

Sources: $\mathrm{CBBH}$; and IMF staff calculations. 
Figure 4. Bosnia and Herzegovina: Financial Sector Indicators, 2004-08

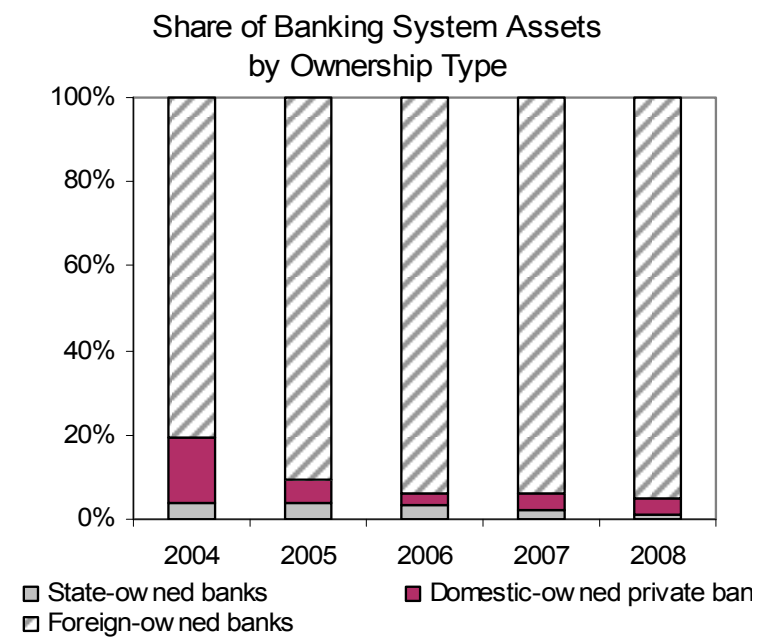

Credit and deposit flows, and Increase in NFL (in percent of GDP)

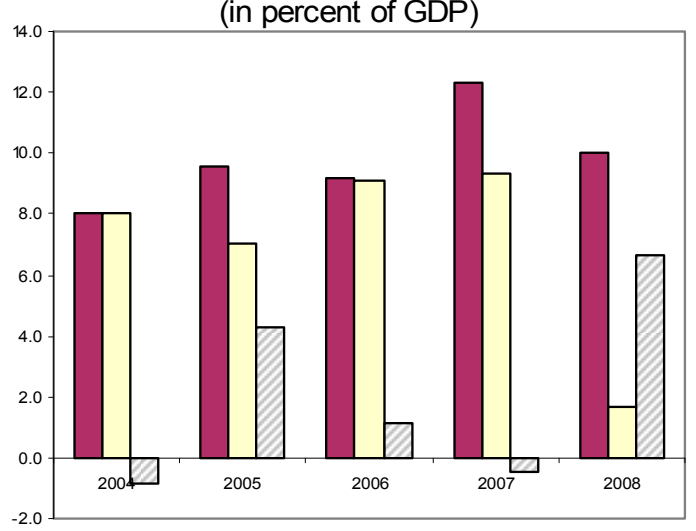

$\square$ Private sector credit flow $\square$ Deposit flow

Increase in net foreign liabilities of banks

Maturity Structure of Credit and Deposits, 2008 (In percent)

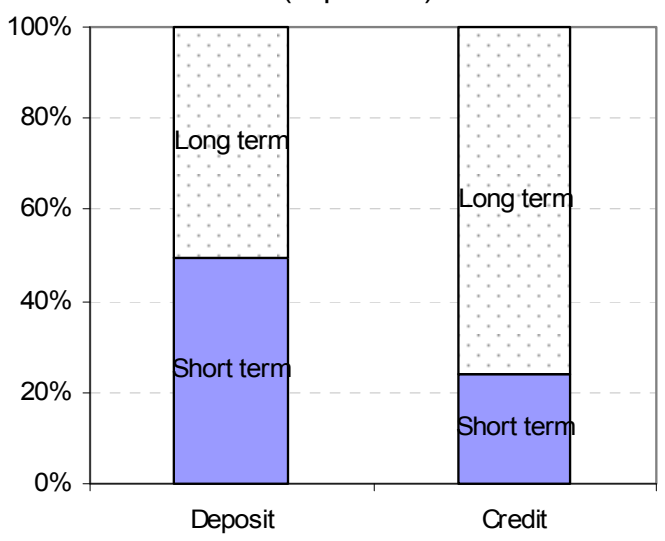

Share of Foreign Currency Loans and Liabilities

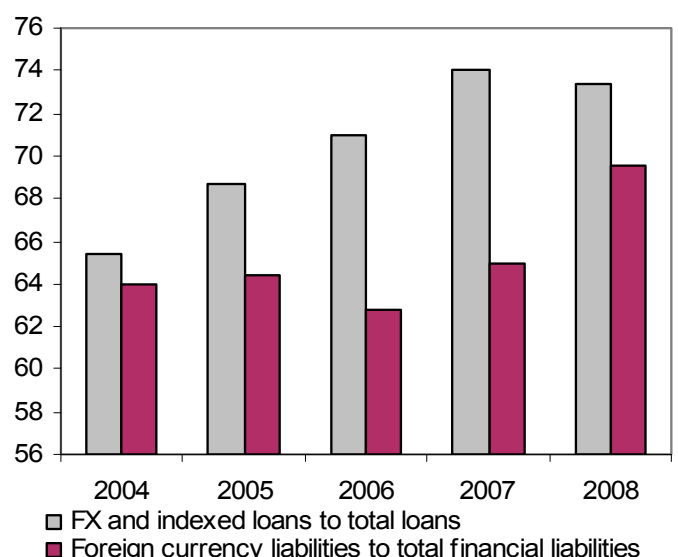

Bank Foreign Liabilities and Capital Inflows (in percent of GDP)

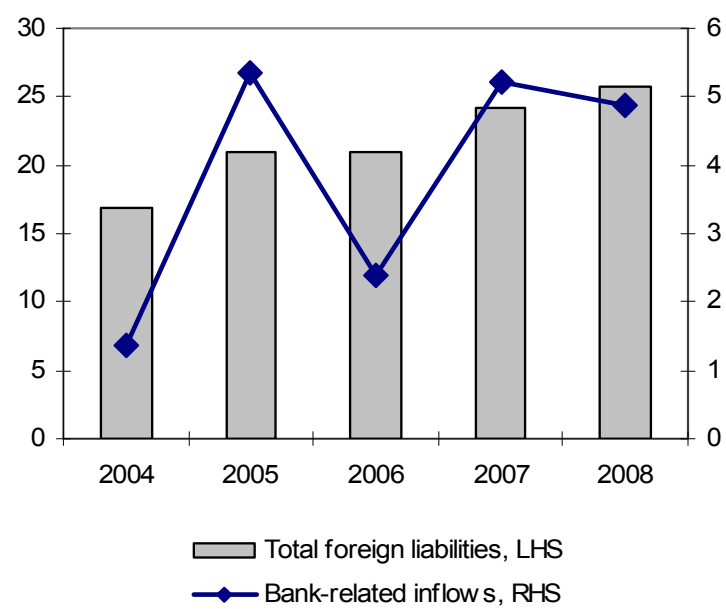

Currency Structure of Credit and Deposits, 2008 (In percent)

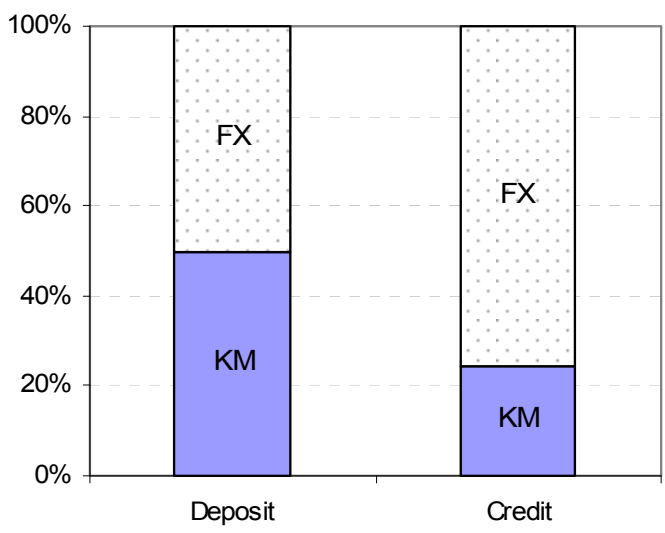


Figure 5. Bosnia and Herzegovina: Central Bank's Foreign Assets and Commercial Bank Reserves, 2008-09
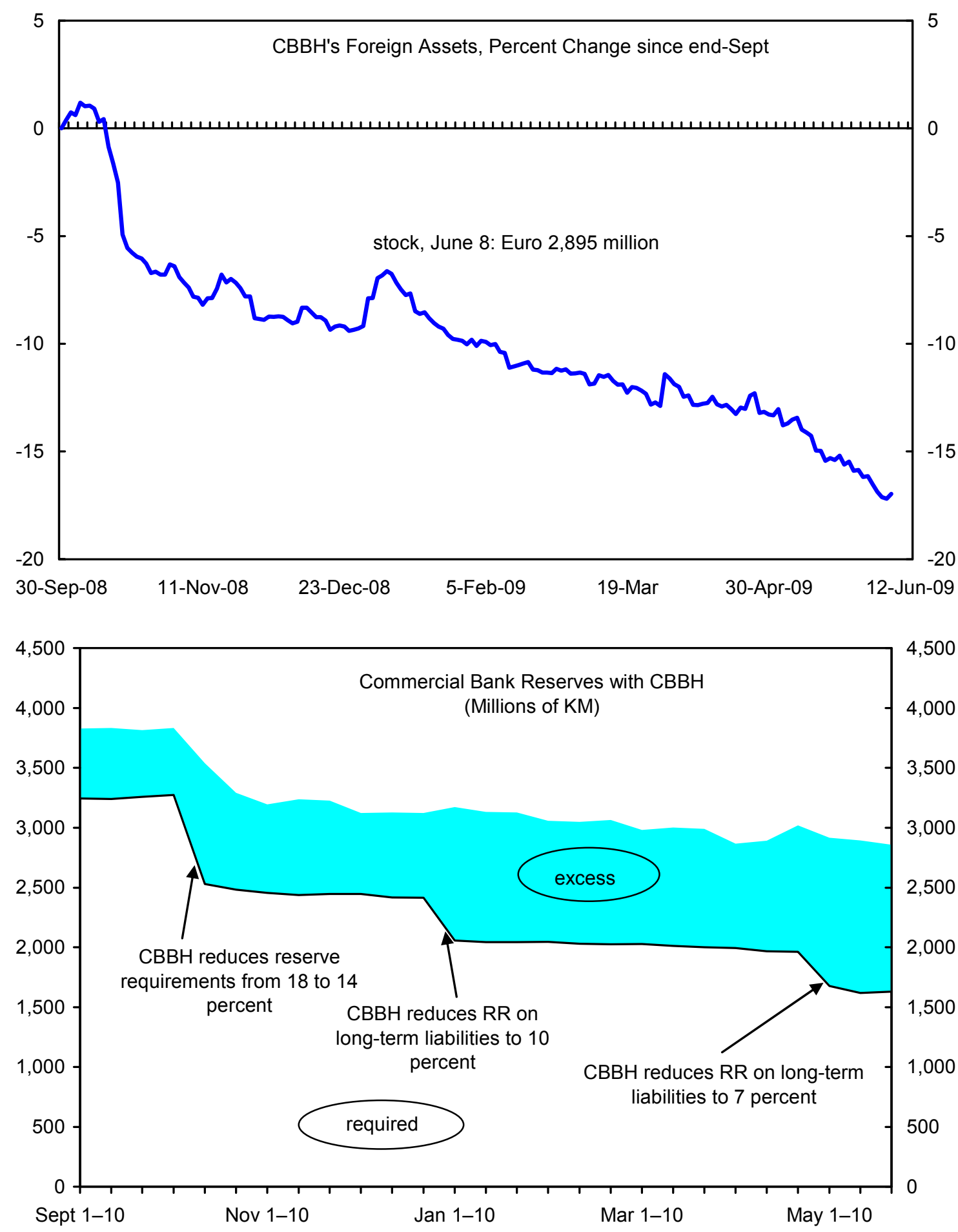

Sources: $\mathrm{CBBH}$; and IMF staff calculations. 
Figure 6. Bosnia and Herzegovina: External Trade, 2004-09
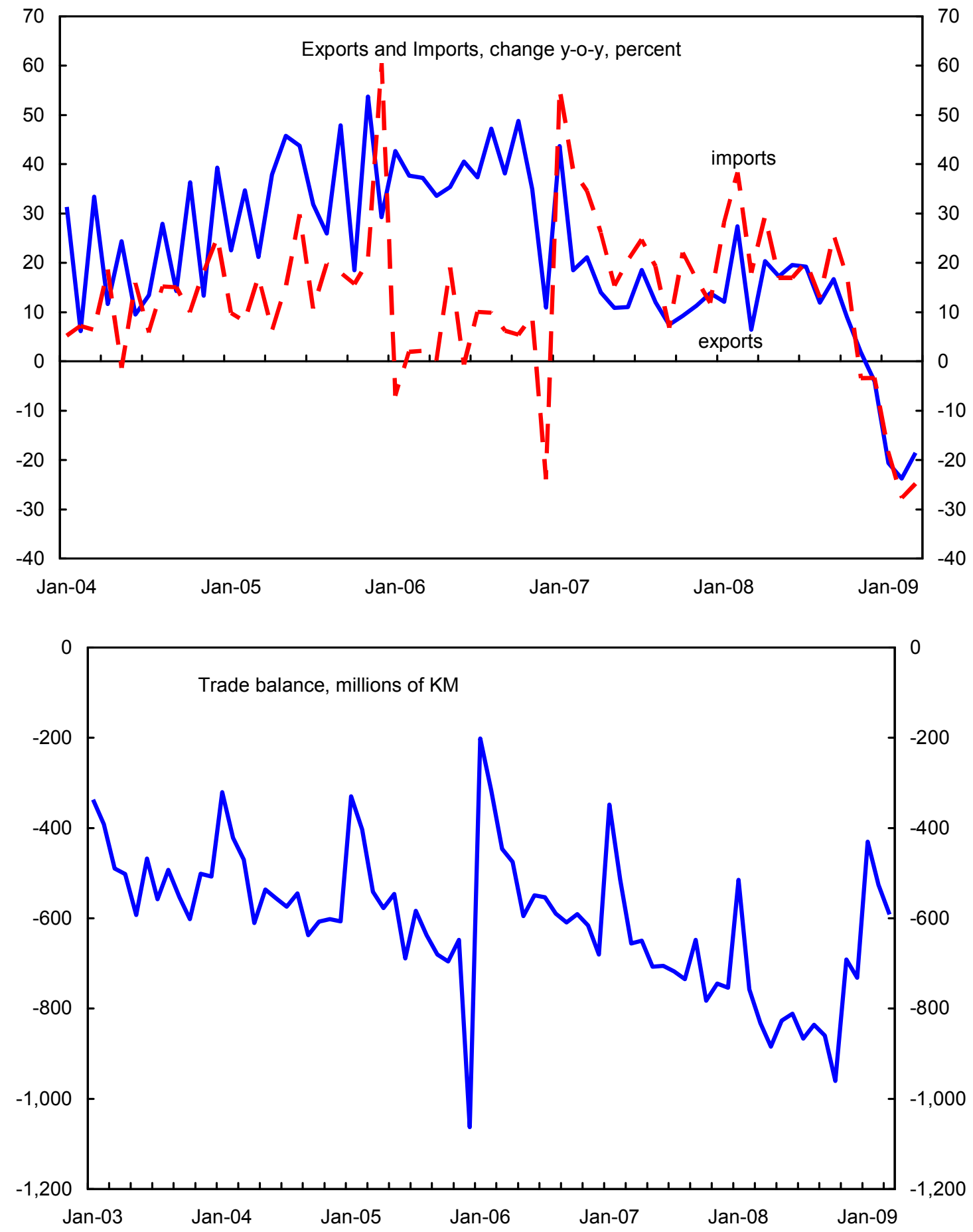

Sources: CBBH; and IMF staff calculations. 
Figure 7. Bosnia and Herzegovina: Wage Developments, January 2005-March 2009

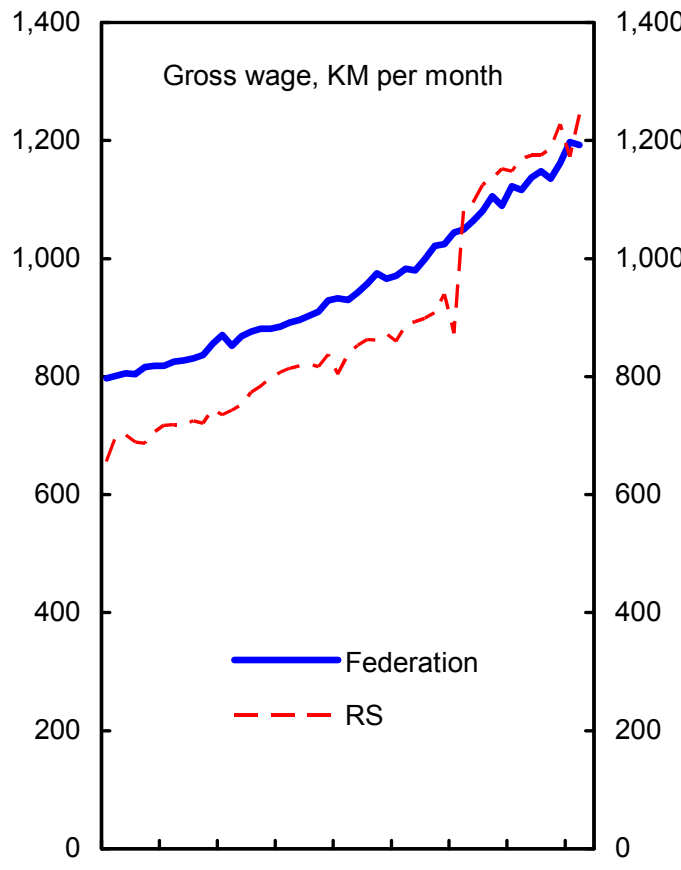

2005m1 2006m1 2007m1 2008m1 2009m1

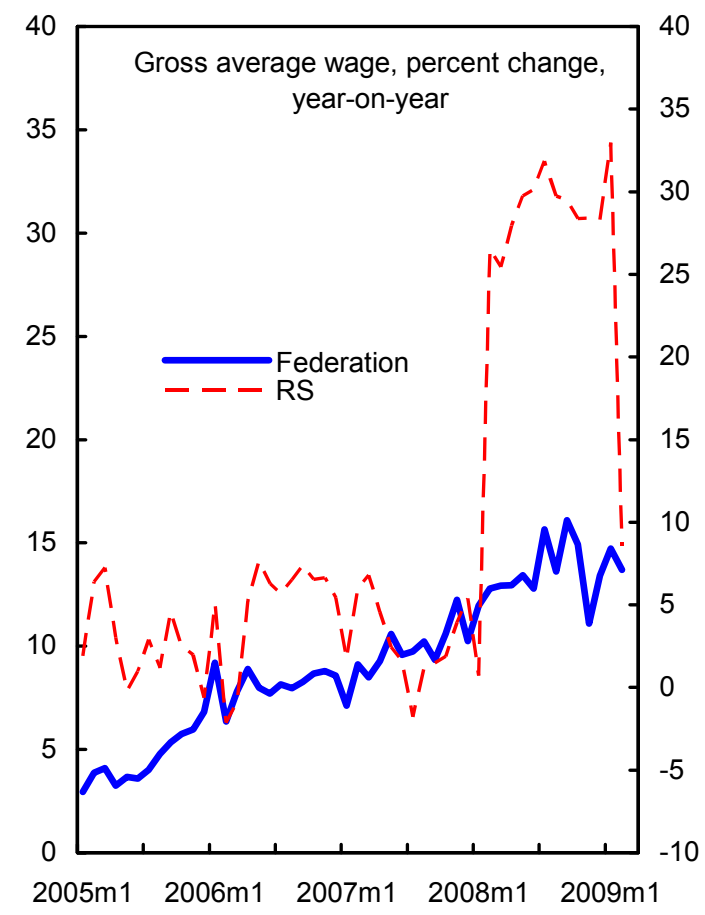

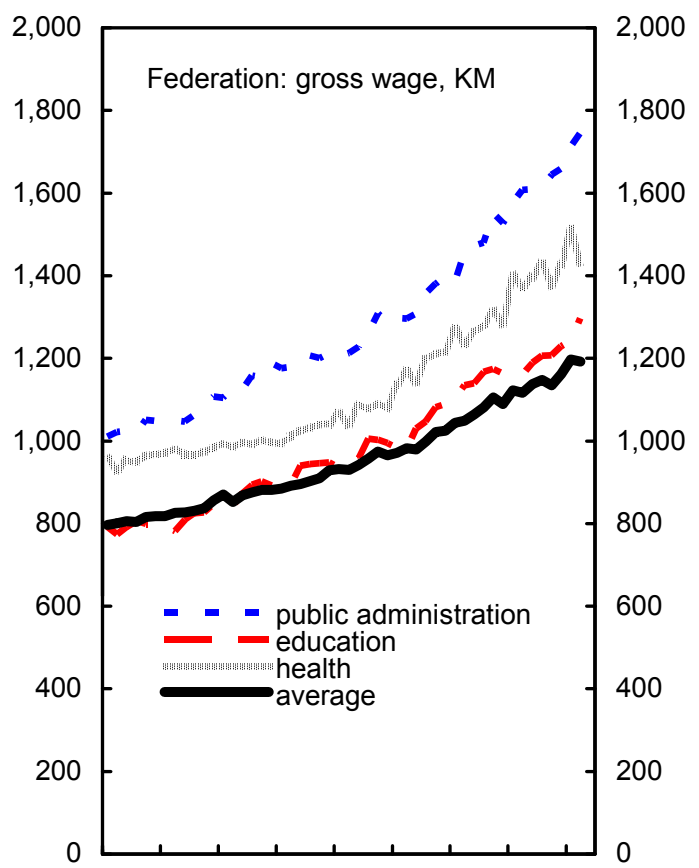

2005m1 2006m1 2007m1 2008m1 2009m1

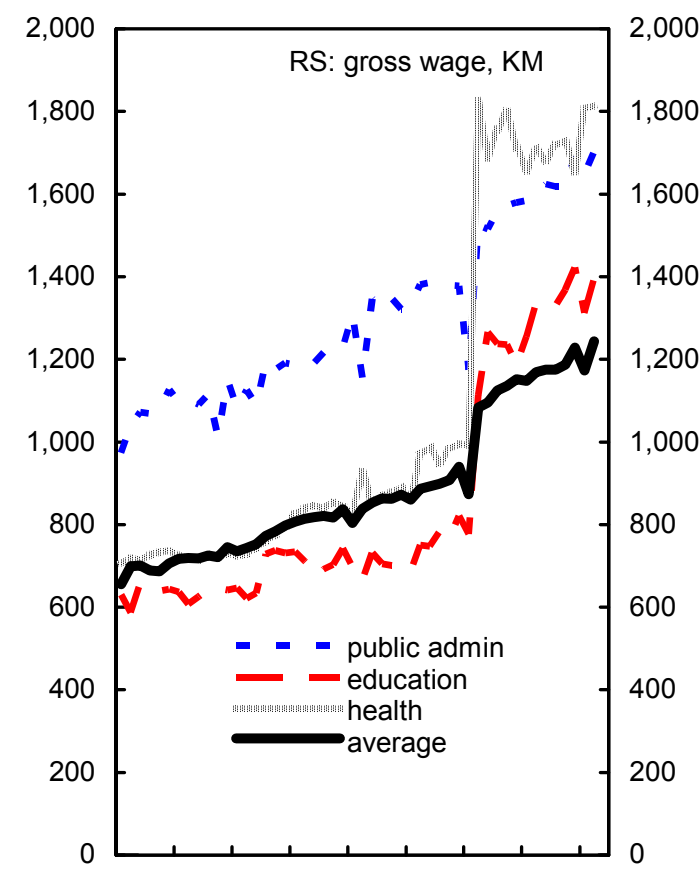

2005m1 2006m1 2007m1 2008m1 2009m1

Sources: BiH authorities; and IMF staff calculations. 
Table 1. Bosnia and Herzegovina: Selected Economic Indicators, 2005-10

\begin{tabular}{|c|c|c|c|c|c|c|}
\hline & 2005 & 2006 & 2007 & 2008 & 2009 & 2010 \\
\hline & & & & \multicolumn{3}{|c|}{ Projections } \\
\hline Nominal GDP (millions of KM) & 16,928 & 19,121 & 21,640 & 24,545 & 24,298 & 25,036 \\
\hline Gross national saving (in percent of GDP) & 9.4 & 12.6 & 12.3 & 9.7 & 10.6 & 13.4 \\
\hline \multirow[t]{2}{*}{ Gross investment (in percent of GDP) } & 27.4 & 20.9 & 25.0 & 24.4 & 20.2 & 23.1 \\
\hline & \multicolumn{6}{|c|}{ (Percent change) } \\
\hline Real GDP & 3.9 & 6.9 & 6.8 & 5.5 & -3.0 & 0.5 \\
\hline Index of industrial production (period average) & 11.1 & 10.5 & 8.1 & 10.2 & -3.0 & 0.5 \\
\hline Gross wages (period average) & 5.6 & 9.1 & 10.2 & 17.0 & 3.2 & 2.7 \\
\hline CPI (period average) & 3.6 & 6.1 & 1.5 & 7.4 & 1.6 & 2.3 \\
\hline \multicolumn{7}{|l|}{ Money and credit (end of period) } \\
\hline Broad money & 18.2 & 24.7 & 21.6 & 4.3 & 0.6 & 3.9 \\
\hline Credit to economy & 27.5 & 23.3 & 28.1 & 20.8 & 0.0 & 4.0 \\
\hline & \multicolumn{6}{|c|}{ (In percent of GDP) } \\
\hline \multicolumn{7}{|l|}{ General government budget 1/ } \\
\hline Revenue & 45.5 & 47.4 & 47.4 & 45.8 & 45.0 & 45.9 \\
\hline Of which: grants & 3.0 & 2.6 & 3.2 & 2.1 & 2.3 & 3.0 \\
\hline Expenditure (on a commitment basis) & 44.7 & 45.2 & 47.5 & 49.9 & 49.7 & 49.9 \\
\hline Of which: investment expenditure & 6.9 & 6.1 & 6.7 & 6.0 & 7.1 & 7.9 \\
\hline Primary balance & 1.4 & 2.9 & 0.5 & -3.5 & -3.8 & -3.0 \\
\hline Overall balance & 0.8 & 2.2 & -0.1 & -4.0 & -4.7 & -4.0 \\
\hline External public debt & 25.6 & 21.2 & 18.3 & 17.1 & 21.5 & 26.3 \\
\hline NPV of external public debt & 19.6 & 16.2 & 14.0 & 13.0 & 16.5 & 20.1 \\
\hline Total public debt $2 /$ & 25.6 & 22.0 & 29.8 & 27.8 & 34.7 & 39.8 \\
\hline & \multicolumn{6}{|c|}{ (In millions of euros, unless noted otherwise) } \\
\hline \multicolumn{7}{|l|}{ Balance of payments } \\
\hline Exports of goods and services & 2,832 & 3,589 & 4,062 & 4,580 & 3,843 & 4,108 \\
\hline Imports of goods and services & 6,393 & 6,493 & 7,656 & 8,688 & 7,050 & 7,476 \\
\hline Unrequited transfers, net & 1,628 & 1,762 & 1,853 & 1,844 & 1,771 & 1,903 \\
\hline Current account balance & $-1,555$ & -816 & $-1,401$ & $-1,842$ & $-1,201$ & $-1,234$ \\
\hline (In percent of GDP) & -18.0 & -8.4 & -12.7 & -14.7 & -9.7 & -9.6 \\
\hline Foreign direct investment & 477 & 562 & 1,471 & 529 & 258 & 500 \\
\hline (In percent of GDP) & 5.5 & 5.8 & 13.3 & 4.2 & 2.1 & 3.9 \\
\hline Gross official reserves & 2,145 & 2,761 & 3,425 & 3,219 & 2,932 & 3,007 \\
\hline (In months of imports) & 4.0 & 4.3 & 4.7 & 5.5 & 4.7 & 4.5 \\
\hline External debt, percent of GDP & 51.3 & 47.9 & 47.5 & 44.5 & 52.4 & 56.7 \\
\hline External debt service & 267 & 412 & 326 & 364 & 433 & 504 \\
\hline (In percent of exports of goods and services) & 9.4 & 11.5 & 8.0 & 8.0 & 11.3 & 12.3 \\
\hline
\end{tabular}

Sources: BiH authorities; and IMF staff estimates and projections.

1/ 2009 based on program.

2/ Increase in 2007 reflects the recognition of domestic claims (mainly frozen foreign currency deposits and war damages). 
Table 2. Bosnia and Herzegovina: Balance of Payments, 2006-14 (In millions of euros, unless otherwise indicated)

\begin{tabular}{|c|c|c|c|c|c|c|c|c|c|}
\hline & 2006 & 2007 & 2008 & 2009 & 2010 & 2011 & 2012 & 2013 & 2014 \\
\hline & & & Est. & \multicolumn{6}{|c|}{ Projections } \\
\hline Merchandise trade & $-3,406$ & $-4,142$ & $-4,797$ & $-3,912$ & $-4,096$ & $-4,280$ & $-4,488$ & $-4,719$ & $-4,985$ \\
\hline Exports, f.o.b. & 2,687 & 3,092 & 3,451 & 2,713 & 2,941 & 3,292 & 3,635 & 4,010 & 4,415 \\
\hline Imports, f.o.b. & $-6,093$ & $-7,234$ & $-8,248$ & $-6,625$ & $-7,037$ & $-7,572$ & $-8,123$ & $-8,729$ & $-9,400$ \\
\hline Reconstruction & -200 & -177 & -194 & -321 & -357 & -371 & -390 & -367 & -383 \\
\hline Other & $-5,893$ & $-7,057$ & $-8,054$ & $-6,304$ & $-6,680$ & $-7,201$ & $-7,733$ & $-8,363$ & $-9,018$ \\
\hline Services, net & 501 & 548 & 689 & 704 & 728 & 776 & 832 & 896 & 978 \\
\hline Exports & 901 & 970 & 1,129 & 1,130 & 1,167 & 1,239 & 1,326 & 1,421 & 1,534 \\
\hline Imports & -400 & -422 & -440 & -425 & -439 & -463 & -494 & -525 & -556 \\
\hline Income, net & 326 & 340 & 422 & 235 & 231 & 216 & 220 & 228 & 244 \\
\hline Credit & 582 & 650 & 768 & 535 & 535 & 554 & 586 & 621 & 657 \\
\hline Debit & -256 & -310 & -346 & -300 & -304 & -338 & -366 & -393 & -413 \\
\hline Of which: interest & -97 & -133 & -99 & -125 & -147 & -183 & -209 & -221 & -217 \\
\hline Current transfers, net & 1,762 & 1,853 & 1,844 & 1,771 & 1,903 & 1,996 & 2,089 & 2,256 & 2,391 \\
\hline Receipts & 1,942 & 2,048 & 2,009 & 1,944 & 2,085 & 2,187 & 2,291 & 2,469 & 2,615 \\
\hline Public & 237 & 191 & 154 & 180 & 272 & 304 & 323 & 370 & 371 \\
\hline Private & 1,705 & 1,857 & 1,855 & 1,764 & 1,813 & 1,883 & 1,968 & 2,099 & 2,244 \\
\hline Payments & -179 & -195 & -164 & -173 & -182 & -192 & -202 & -213 & -224 \\
\hline Current account balance & -816 & $-1,401$ & $-1,842$ & $-1,201$ & $-1,234$ & $-1,293$ & $-1,347$ & $-1,338$ & $-1,372$ \\
\hline Capital and Financial Accounts & 1,237 & 1,839 & 1,530 & 481 & 747 & 1,169 & 1,457 & 1,600 & 1,602 \\
\hline Capital account & 234 & 215 & 202 & 218 & 230 & 242 & 266 & 288 & 311 \\
\hline Capital transfers & 234 & 215 & 202 & 218 & 230 & 242 & 266 & 288 & 311 \\
\hline Official transfers & 118 & 103 & 91 & 106 & 112 & 122 & 133 & 146 & 160 \\
\hline Private transfers & 115 & 111 & 111 & 112 & 118 & 120 & 133 & 142 & 152 \\
\hline Financial account & 1,003 & 1,625 & 1,328 & 263 & 517 & 927 & 1,190 & 1,312 & 1,291 \\
\hline Direct investment & 562 & 1,471 & 529 & 258 & 500 & 900 & 990 & 990 & 990 \\
\hline Outward & -2 & -7 & -1 & 0 & 0 & 0 & 0 & 0 & 0 \\
\hline Inward & 564 & 1,478 & 530 & 258 & 500 & 900 & 990 & 990 & 990 \\
\hline Portfolio investment & 0 & 1 & -2 & 0 & 0 & 0 & 0 & 0 & 0 \\
\hline Other investment & 440 & 153 & 800 & 5 & 17 & 27 & 200 & 322 & 301 \\
\hline Assets (increase, -) & 78 & -572 & 14 & 103 & 59 & -138 & -88 & 61 & 96 \\
\hline Commercial banks & -118 & -616 & 230 & 82 & 50 & -150 & -100 & 48 & 46 \\
\hline Other & 196 & 44 & -217 & 21 & 9 & 12 & 12 & 13 & 50 \\
\hline Liabilities & 363 & 725 & 786 & -98 & -42 & 165 & 288 & 261 & 205 \\
\hline Trade credits & 176 & 203 & 210 & -5 & 70 & 105 & 120 & 150 & 244 \\
\hline Commercial banks & 350 & 411 & 425 & 0 & 0 & 194 & 273 & 295 & 319 \\
\hline Amortization & -269 & -175 & -228 & -308 & -357 & -382 & -362 & -405 & -582 \\
\hline Drawing of loans & 107 & 285 & 380 & 215 & 245 & 248 & 257 & 220 & 223 \\
\hline Project & 82 & 74 & 103 & 215 & 245 & 248 & 257 & 220 & 223 \\
\hline Program & 10 & 0 & 0 & 0 & 0 & 0 & 0 & 0 & 0 \\
\hline Reserve assets (increase, - ) & -627 & -637 & 206 & 287 & -75 & -178 & -301 & -261 & -230 \\
\hline Net Errors and Omissions & 207 & 199 & 106 & $\ldots$ & $\cdots$ & $\cdots$ & $\ldots$ & $\ldots$ & $\ldots$ \\
\hline External financing gap & $\ldots$ & $\ldots$ & $\ldots$ & 433 & 563 & 302 & 191 & 0 & 0 \\
\hline \multicolumn{10}{|l|}{ Memorandum items: } \\
\hline Current account balance (percent of GDP) & -8.4 & -12.7 & -14.7 & -9.7 & -9.6 & -9.5 & -9.1 & -8.3 & -8.0 \\
\hline Trade balance (percent of GDP) & -34.8 & -37.4 & -38.2 & -31.5 & -32.0 & -31.4 & -30.3 & -29.3 & -28.9 \\
\hline Import of goods (change, percent) & 1.2 & 18.7 & 14.0 & -19.7 & 6.2 & 7.6 & 7.3 & 7.5 & 7.7 \\
\hline Export of goods (change, percent) & 30.5 & 15.0 & 11.6 & -21.4 & 8.4 & 11.9 & 10.4 & 10.3 & 10.1 \\
\hline Transfers (percent of GDP) & 18.0 & 16.7 & 14.7 & 14.3 & 14.9 & 14.6 & 14.1 & 14.0 & 13.9 \\
\hline Net foreign direct investment (percent of GDP) & 5.8 & 13.3 & 4.2 & 2.1 & 3.9 & 6.6 & 6.7 & 6.1 & 5.7 \\
\hline External debt/GDP (percent) & 47.9 & 47.5 & 44.5 & 52.4 & 56.7 & 58.2 & 57.7 & 54.6 & 51.3 \\
\hline Private & 26.7 & 29.2 & 27.4 & 30.8 & 30.4 & 30.4 & 30.1 & 29.9 & 29.8 \\
\hline Public & 21.2 & 18.3 & 17.1 & 21.5 & 26.3 & 27.8 & 27.6 & 24.7 & 21.5 \\
\hline External public debt service/exports of G\&S (percent) & 11.5 & 8.0 & 8.0 & 11.3 & 12.3 & 12.5 & 11.5 & 11.5 & 13.4 \\
\hline Gross official reserves & 2,761 & 3,425 & 3,219 & 2,932 & 3,007 & 3,185 & 3,486 & 3,747 & 3,978 \\
\hline (Months of imports of goods and services) & 4.3 & 4.7 & 5.5 & 4.7 & 4.5 & 4.4 & 4.5 & 4.5 & 4.5 \\
\hline Nominal GDP & 9,776 & 11,064 & 12,549 & 12,423 & 12,801 & 13,629 & 14,823 & 16,102 & 17,244 \\
\hline
\end{tabular}

Sources: BiH authorities; and IMF staff estimates and projections. 
Table 3. Bosnia and Herzegovina: Selected Vulnerability Indicators, 2004-08

\begin{tabular}{|c|c|c|c|c|c|c|c|}
\hline \multirow{3}{*}{ External sector } & \multirow{3}{*}{2004} & \multirow{3}{*}{2005} & \multirow{3}{*}{2006} & \multirow{3}{*}{2007} & \multicolumn{2}{|l|}{2008} & \\
\hline & & & & & Est. & \multicolumn{2}{|c|}{ Latest observation } \\
\hline & & & & & & & \\
\hline Exports of goods (change, percent, in euros) & 28.7 & 22.8 & 30.5 & 15.0 & 11.6 & -20.4 & Mar-09 \\
\hline Imports of goods (change, percent, in euros) & 7.6 & 12.5 & 1.2 & 18.7 & 14.0 & -22.8 & Mar-09 \\
\hline Terms of trade (change, percent) & 3.4 & 5.6 & 7.9 & 10.1 & -3.5 & -3.5 & 2008 \\
\hline Current account balance (percent of GDP) & -16.3 & -18.0 & -8.4 & -12.7 & -14.7 & -14.7 & 2008 \\
\hline Capital and financial account (percent of GDP) & 16.8 & 19.7 & 12.7 & 16.6 & 12.2 & 12.2 & 2008 \\
\hline Net FDI inflows (percent of GDP) & 7.0 & 5.5 & 5.8 & 13.3 & 4.2 & 4.2 & 2008 \\
\hline Gross international reserves (end of period, millions of euros) & 1,768 & 2,145 & 2,761 & 3,425 & 3,219 & 3,110 & Mar-09 \\
\hline In months of imports of goods and services & 3.3 & 4.0 & 4.3 & 4.7 & 5.5 & 5.5 & 2008 \\
\hline In percent of short-term debt at remaining maturity & 473.0 & 476.6 & 752.9 & 422.5 & 325.1 & 325.1 & 2008 \\
\hline In percent of reserve money & 106.7 & 105.7 & 106.9 & 107.5 & 110.4 & 114.4 & Mar-09 \\
\hline Total gross external debt (percent of GDP) & 49.2 & 51.3 & 47.9 & 47.5 & 44.5 & 44.5 & 2008 \\
\hline Of which short-term external debt (remaining maturity, percent of GDP) & 5.4 & 7.1 & 5.4 & 6.8 & 6.4 & 6.4 & 2008 \\
\hline Of which extermal public debt (percent of GDP) & 25.5 & 25.6 & 21.2 & 18.3 & 17.1 & 17.1 & 2008 \\
\hline REER (annual average percentage change; depreciation =-) & -1.6 & 0.8 & 2.2 & -1.8 & 2.2 & 2.2 & 2008 \\
\hline Exchange rate (per U.S. dollar, period average) & 1.6 & 1.6 & 1.6 & 1.4 & 1.3 & 1.3 & 2008 \\
\hline \multicolumn{8}{|l|}{ Financial and financial market indicators } \\
\hline Broad money (change, percent) & 24.3 & 18.2 & 24.7 & 21.6 & 4.4 & 0.8 & Mar-09 \\
\hline Credit to private sector (change, percent) & 27.5 & 27.5 & 23.3 & 28.1 & 20.8 & 12.6 & Mar-09 \\
\hline Credit to private sector (percent of GDP) & 37.3 & 44.3 & 48.4 & 56.1 & 58.3 & 58.3 & Mar-09 \\
\hline \multicolumn{8}{|l|}{ Interest rates } \\
\hline Average annual interest rates on KM loans to enterprises $1 /$ & 9.6 & 8.9 & 8.0 & 7.2 & 7.4 & 7.5 & Mar-09 \\
\hline Average annual interest rates on $\mathrm{KM}$ loans to households $2 /$ & 10.9 & 10.4 & 9.7 & 9.9 & 10.0 & 9.3 & Mar-09 \\
\hline Average annual interest rates on foreign currency-linked loans to enterprises $1 /$ & $\ldots$ & $\ldots$ & $\ldots$ & 7.9 & 8.7 & 9.1 & Mar-09 \\
\hline Average annual interest rates on foreign currency-linked loans to households $2 /$ & $\ldots$ & $\ldots$ & $\ldots$ & 8.9 & 10.0 & 10.6 & Mar-09 \\
\hline \multicolumn{8}{|l|}{ Stock market indices, end of period } \\
\hline Banja Luka Stock Exchange 3/ & 1,150 & 1,367 & 2,885 & 2,564 & 1,028 & 960 & May-09 \\
\hline Sarajevo Stock Exchange 4/ & $\ldots$ & 1,612 & 2,856 & 3,685 & 1,234 & 1,021 & May-09 \\
\hline Foreign currency debt rating $5 /$ & B3 & B3 & B2 & B2 & B2 & B2 & May-09 \\
\hline Outlook & Positive & Positive & Stable & Stable & Stable & Stable & May-09 \\
\hline
\end{tabular}

1/ Simple average between short-term and long-term rates.

2/ Long-term rates.

3/ Banja Luka Stock Exchange's BIRS index.

4/ Sarajevo Stock Exchange's SASX-10 index

$5 /$ Moody's foreign currency sovereign rating. 
Table 4. Bosnia and Herzegovina: General Government, 2006-14 (In percent of GDP)

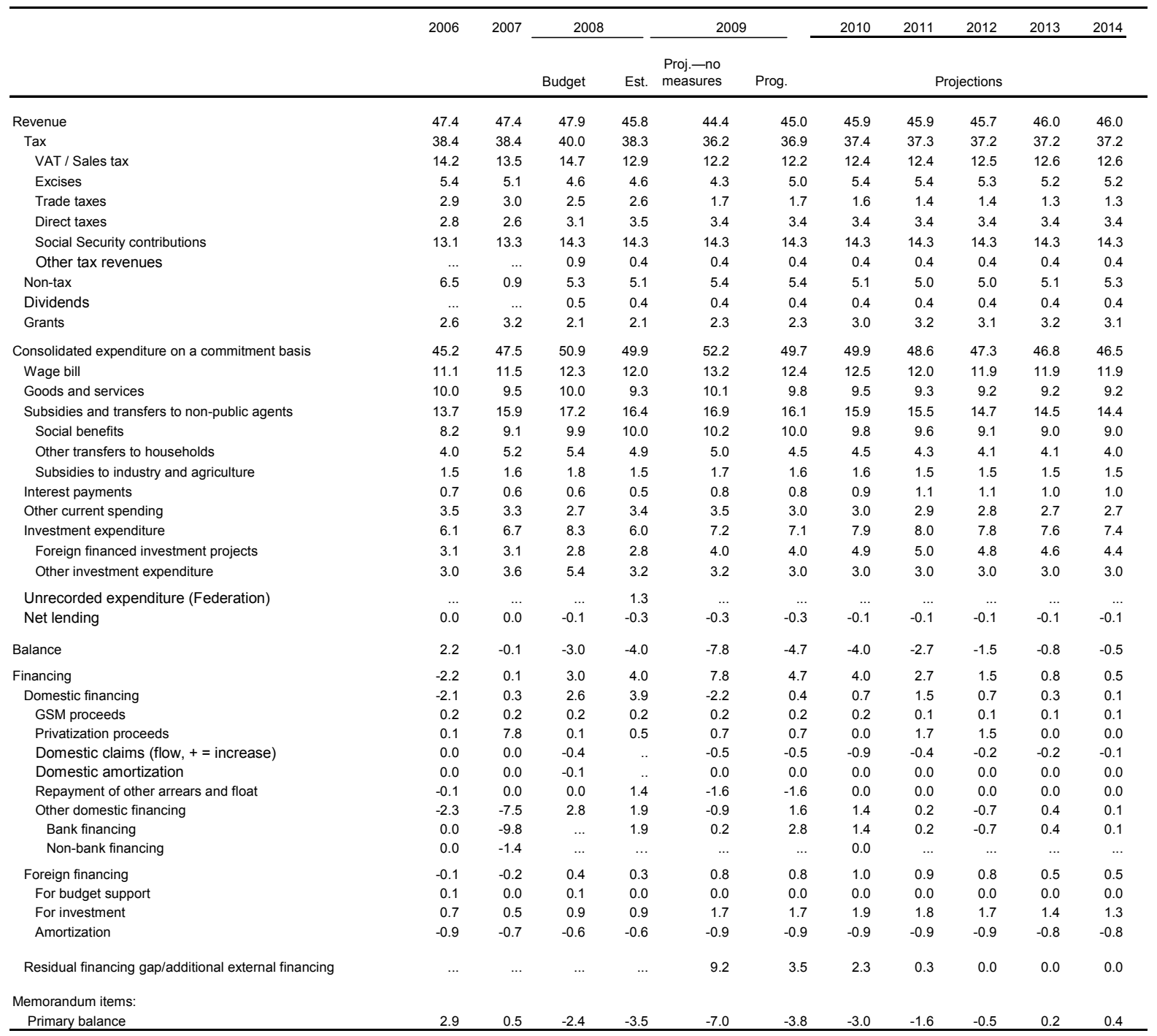

Sources: Ministries of Finance; and IMF staff estimates. 
Table 5. Bosnia and Herzegovina: Elements of General Government, 2008-14

(In percent of GDP)

\begin{tabular}{|c|c|c|c|c|c|c|c|}
\hline & 2008 & 2009 & 2010 & 2011 & 2012 & 2013 & 2014 \\
\hline & Est. & \multicolumn{6}{|c|}{ Projections } \\
\hline \multicolumn{8}{|l|}{ Federation budget } \\
\hline Revenue and grants & 5.3 & 5.3 & 4.1 & 5.4 & 5.3 & 5.3 & 5.3 \\
\hline Expenditure & 5.9 & 5.5 & 5.2 & 5.2 & 4.9 & 4.9 & 4.8 \\
\hline Of which: transfers to other levels of government & 0.4 & 0.4 & 0.4 & 0.4 & 0.4 & 0.4 & 0.4 \\
\hline Balance & -0.6 & -0.1 & -1.1 & 0.1 & 0.4 & 0.4 & 0.5 \\
\hline \multicolumn{8}{|l|}{ Federation Road Fund } \\
\hline Revenue and grants & 0.5 & 0.5 & 0.6 & 0.5 & 0.5 & 0.5 & 0.5 \\
\hline Of which: transfers from the Federation budget & 0.0 & 0.0 & 0.0 & 0.0 & 0.0 & 0.0 & 0.0 \\
\hline Expenditure & 0.5 & 0.6 & 0.5 & 0.5 & 0.5 & 0.5 & 0.5 \\
\hline Balance & 0.0 & -0.1 & 0.1 & 0.0 & 0.0 & 0.0 & 0.0 \\
\hline \multicolumn{8}{|l|}{ Cantonal and municipal budgets } \\
\hline Revenue and grants & 11.1 & 10.4 & 11.2 & 9.9 & 9.8 & 9.9 & 9.9 \\
\hline Of which: transfers from the Federation budget & -0.4 & -0.4 & 0.0 & 0.0 & 0.0 & 0.0 & 0.0 \\
\hline Expenditure & 11.7 & 10.8 & 10.2 & 10.1 & 9.7 & 9.6 & 9.5 \\
\hline Balance & -0.6 & -0.4 & 1.1 & -0.2 & 0.1 & 0.3 & 0.4 \\
\hline \multicolumn{8}{|l|}{ Federation extra-budgetary Funds } \\
\hline Revenue and grants & 11.1 & 10.8 & 10.8 & 10.8 & 10.8 & 11.0 & 11.2 \\
\hline Of which: transfers from the Federation budget & 0.7 & 0.4 & 0.4 & 0.4 & 0.4 & 0.4 & 0.4 \\
\hline Expenditure & 11.3 & 11.2 & 11.2 & 11.0 & 10.4 & 10.4 & 10.4 \\
\hline Balance & -0.2 & -0.5 & -0.4 & -0.2 & 0.3 & 0.5 & 0.7 \\
\hline \multicolumn{8}{|l|}{ RS budget and municipalities } \\
\hline Revenue and grants & 8.7 & 7.6 & 7.8 & 7.8 & 7.8 & 7.9 & 8.0 \\
\hline Expenditure & 9.7 & 9.1 & 8.9 & 8.3 & 8.0 & 8.0 & 8.0 \\
\hline Of which: transfers to other levels of government & 1.0 & 1.1 & 0.9 & 0.7 & 0.5 & 0.5 & 0.5 \\
\hline Balance & -1.0 & -1.5 & -1.1 & -0.5 & -0.1 & -0.1 & 0.1 \\
\hline \multicolumn{8}{|l|}{ RS Road Fund } \\
\hline Revenue and grants & 0.4 & 0.4 & 0.4 & 0.3 & 0.3 & 0.3 & 0.3 \\
\hline Of which: transfers from the RS budget & 0.1 & 0.0 & 0.0 & 0.0 & 0.0 & 0.0 & 0.0 \\
\hline Expenditure & 0.5 & 0.4 & 0.4 & 0.4 & 0.4 & 0.4 & 0.4 \\
\hline Balance & -0.1 & 0.0 & 0.0 & -0.1 & -0.1 & -0.1 & -0.1 \\
\hline \multicolumn{8}{|l|}{ RS extra-budgetary funds } \\
\hline Revenue and grants & 5.0 & 5.1 & 5.0 & 4.8 & 4.6 & 4.4 & 4.3 \\
\hline Of which: transfers from the RS budget & 0.9 & 1.0 & 0.9 & 0.7 & 0.5 & 0.5 & 0.5 \\
\hline Expenditure & 5.2 & 5.3 & 5.1 & 4.9 & 5.1 & 5.1 & 5.1 \\
\hline Balance & -0.1 & -0.2 & -0.1 & -0.1 & -0.5 & -0.7 & -0.8 \\
\hline \multicolumn{8}{|l|}{ State } \\
\hline Revenue and grants & 3.5 & 3.9 & 3.5 & 3.6 & 3.5 & 3.5 & 3.5 \\
\hline Of which: transfers from other levels of government & 0.0 & 0.0 & 0.0 & 0.0 & 0.0 & 0.0 & 0.0 \\
\hline Expenditure & 3.4 & 4.2 & 4.0 & 3.6 & 3.5 & 3.5 & 3.5 \\
\hline Balance & 0.1 & -0.3 & -0.5 & 0.0 & 0.0 & 0.0 & 0.0 \\
\hline \multicolumn{8}{|l|}{ ITA } \\
\hline Balance & -0.2 & $\ldots$ & $\ldots$ & $\ldots$ & $\ldots$ & $\ldots$ & $\ldots$ \\
\hline \multicolumn{8}{|l|}{ Brcko District } \\
\hline Revenue and grants & 0.9 & 0.8 & 0.9 & 0.9 & 0.9 & 0.9 & 0.9 \\
\hline Expenditure & 0.7 & 0.8 & 0.8 & 0.8 & 0.8 & 0.8 & 0.9 \\
\hline Of which: transfers to other levels of government & 0.0 & 0.0 & 0.0 & 0.0 & 0.0 & 0.0 & 0.0 \\
\hline Balance & 0.2 & 0.0 & 0.0 & 0.0 & 0.1 & 0.1 & 0.0 \\
\hline \multicolumn{8}{|l|}{ Foreign-financed investment projects } \\
\hline Grants & 1.9 & 2.3 & 3.0 & 3.1 & 3.1 & 3.2 & 3.1 \\
\hline Expenditure & 2.8 & 4.0 & 4.9 & 5.0 & 4.8 & 4.6 & 4.4 \\
\hline Balance & -0.8 & -1.7 & -1.9 & -1.8 & -1.7 & -1.4 & -1.3 \\
\hline
\end{tabular}

Sources: Ministries of Finance; and IMF staff estimates. 
Table 6. Bosnia and Herzegovina: Monetary Survey, 2006-10 (In millions of KM, unless noted otherwise)

\begin{tabular}{|c|c|c|c|c|c|}
\hline & 2006 & 2007 & 2008 & 2009 & 2010 \\
\hline & & & Est. & \multicolumn{2}{|c|}{ Projections } \\
\hline Net foreign assets & 3,745 & 5,145 & 3,102 & 2,378 & 1,898 \\
\hline Foreign assets & 7,757 & 10,260 & 9,410 & 8,687 & 8,736 \\
\hline Foreign liabilities & 4,012 & 5,115 & 6,309 & 6,309 & 6,838 \\
\hline Domestic credit & 8,411 & 9,801 & 12,993 & 13,762 & 15,007 \\
\hline Claims on central government (net) & -894 & $-2,148$ & $-1,466$ & -720 & -33 \\
\hline Claims on noncentral government & 60 & 111 & 160 & 180 & 170 \\
\hline Claims on private sector & 9,245 & 11,838 & 14,299 & 14,302 & 14,871 \\
\hline Non-financial enterprises and cooperatives & 4,735 & 5,955 & 7,421 & 7,421 & 7,717 \\
\hline Households & 4,373 & 5,685 & 6,696 & 6,696 & 6,964 \\
\hline Other & 136 & 197 & 182 & 185 & 189 \\
\hline Broad money & 10,074 & 12,247 & 12,776 & 12,849 & 13,353 \\
\hline Narrow money & 5,071 & 6,160 & 5,994 & 6,029 & 6,265 \\
\hline Currency outside banks & 1,978 & 2,185 & 2,302 & 2,005 & 1,904 \\
\hline Demand deposits of noncentral government & 571 & 744 & 571 & 643 & 986 \\
\hline Demand deposits of the private sector & 2,522 & 3,231 & 3,121 & 3,381 & 3,375 \\
\hline Quasi-money & 5,002 & 6,087 & 6,782 & 6,821 & 7,088 \\
\hline Time and savings deposits in domestic currency & 1,099 & 1,514 & 1,799 & 1,789 & 2,005 \\
\hline Foreign currency deposits & 3,903 & 4,572 & 4,982 & 5,032 & 5,082 \\
\hline Other items (net) & $-2,082$ & $-2,700$ & $-3,319$ & $-3,291$ & $-3,553$ \\
\hline \multicolumn{6}{|l|}{ Memorandum items: } \\
\hline Broad money growth (year-on-year) & 24.7 & 21.6 & 4.3 & 0.6 & 3.9 \\
\hline NDA growth (year-on-year) & 20.6 & 16.5 & 32.6 & 5.9 & 9.0 \\
\hline NFA growth (year-on-year) & 35.9 & 37.4 & -39.7 & -23.3 & -20.2 \\
\hline Domestic credit contribution to broad money growth (year-on-year) & 9.9 & 13.8 & 26.1 & 6.0 & 9.7 \\
\hline NFA contribution to broad money growth (year-on-year) & 12.2 & 13.9 & -16.7 & -5.7 & -3.7 \\
\hline Broad money (in percent of GDP) & 52.7 & 56.6 & 52.1 & 52.9 & 53.3 \\
\hline Domestic credit (in percent of GDP) & 44.0 & 45.3 & 52.9 & 56.6 & 59.9 \\
\hline Private sector credit (in percent of GDP) & 48.3 & 54.7 & 58.3 & 58.9 & 59.4 \\
\hline Credit to household sector (in percent of GDP) & 22.9 & 26.3 & 27.3 & 27.6 & 27.8 \\
\hline Nominal GDP & 19,121 & 21,640 & 24,545 & 24,298 & 25,036 \\
\hline Velocity of Broad Money & 1.9 & 1.8 & 1.9 & 1.9 & 1.9 \\
\hline Broad money multiplier & 2.0 & 2.0 & 2.2 & 2.4 & 2.4 \\
\hline Growth in credit to private sector, percent & 23.3 & 28.1 & 20.8 & 0.0 & 4.0 \\
\hline
\end{tabular}

Sources: $\mathrm{CBBH}$; and IMF staff estimates. 
Table 7. Bosnia and Herzegovina: Monetary Authorities' Balance Sheet 2006-10 (In millions of KM, unless noted otherwise)

\begin{tabular}{|c|c|c|c|c|c|}
\hline & 2006 & 2007 & 2008 & 2009 & 2010 \\
\hline & & & Est. & Projections & \\
\hline Reserve money & 5,052 & 6,229 & 5,704 & 5,137 & 4,755 \\
\hline Currency outside monetary authorities & 2,154 & 2,440 & 2,552 & 2,230 & 2,107 \\
\hline Currency outside banks & 1,978 & 2,185 & 2,302 & 2,005 & 1,904 \\
\hline Commercial bank cash in vaults & 176 & 254 & 250 & 225 & 203 \\
\hline Commercial bank deposits with $\mathrm{CBBH}$ & 2,887 & 3,777 & 3,144 & 2,907 & 2,648 \\
\hline Other demand deposits with $\mathrm{CBBH}$ & 10 & 12 & 7 & 0 & 0 \\
\hline Net foreign assets & 5,427 & 6,725 & 6,323 & 5,760 & 5,378 \\
\hline Domestic credit (net) & -124 & -73 & -21 & -23 & -23 \\
\hline Claims on general government (net) & -126 & -75 & -23 & -25 & -25 \\
\hline Claims on the private sector & 2 & 2 & 2 & 2 & 2 \\
\hline Other items (net) & -252 & -424 & -597 & -600 & -600 \\
\hline \multicolumn{6}{|l|}{ 12-month growth rates (percent) } \\
\hline Reserve money & 27.2 & 23.3 & -8.4 & -9.9 & -7.0 \\
\hline Net foreign assets & 28.5 & 23.9 & -6.0 & -8.9 & -6.6 \\
\hline Net claims on general government & 234.4 & -40.6 & -68.7 & 6.7 & 0.0 \\
\hline \multicolumn{6}{|l|}{ Memorandum items: } \\
\hline NFA in percent of currency outside the banks & 274.3 & 307.8 & 274.6 & 287.3 & 282.4 \\
\hline NFA in percent of broad money & 53.9 & 54.9 & 49.5 & 44.8 & 40.3 \\
\hline
\end{tabular}

Sources: $\mathrm{CBBH}$; and IMF staff estimates. 
Table 8. Bosnia and Herzegovina: Survey of Domestic Money Banks, 2006-10 ( In millions of KM, unless noted otherwise)

\begin{tabular}{|c|c|c|c|c|c|}
\hline & \multirow[t]{2}{*}{2006} & \multirow[t]{2}{*}{2007} & \multirow{2}{*}{$\begin{array}{r}2008 \\
\text { Est. }\end{array}$} & 2009 & 2010 \\
\hline & & & & \multicolumn{2}{|c|}{ Projections } \\
\hline Net Foreign Assets & $-1,683$ & $-1,580$ & $-3,221$ & $-3,382$ & $-3,480$ \\
\hline Assets & 2,329 & 3,534 & 3,087 & 2,926 & 2,828 \\
\hline Liabilities & 4,011 & 5,114 & 6,308 & 6,308 & 6,308 \\
\hline Net Domestic Assets & 9,768 & 11,629 & 13,687 & 14,227 & 14,928 \\
\hline Net claims on central government & -768 & $-2,073$ & $-1,442$ & -695 & -8 \\
\hline credits & 8 & 16 & 104 & 208 & 208 \\
\hline deposits & 776 & 2,089 & 1,547 & 903 & 217 \\
\hline Claims on non-central government & 60 & 111 & 160 & 180 & 170 \\
\hline Claims on private sector & 9,243 & 11,836 & 14,297 & 14,300 & 14,869 \\
\hline households & 4,373 & 5,685 & 6,696 & 6,696 & 6,964 \\
\hline non-financial enterprises and cooperatives & 4,735 & 5,955 & 7,421 & 7,421 & 7,717 \\
\hline other & 134 & 195 & 180 & 183 & 187 \\
\hline Reserves & 2,887 & 3,777 & 3,144 & 2,907 & 2,648 \\
\hline required reserves & 1,818 & 2,458 & 2,425 & 1,887 & 1,509 \\
\hline excess reserves & 1,069 & 1,320 & 719 & 1,020 & 1,139 \\
\hline Cash in vaults, not included in reserves & 176 & 254 & 250 & 225 & 203 \\
\hline Other Items (net) & $-1,831$ & $-2,276$ & $-2,721$ & $-2,691$ & $-2,953$ \\
\hline Deposits (excl. central government) & 8,085 & 10,049 & 10,467 & 10,845 & 11,448 \\
\hline Deposits in foreign currency & 3,903 & 4,572 & 4,982 & 5,032 & 5,082 \\
\hline Deposits in domestic currency & 4,182 & 5,477 & 5,484 & 5,813 & 6,366 \\
\hline \multicolumn{6}{|l|}{ Memorandum items: } \\
\hline Nominal GDP & 19,121 & 21,640 & 24,545 & 24,298 & 25,036 \\
\hline Credit to private sector & 9,243 & 11,836 & 14,297 & 14,300 & 14,869 \\
\hline 12-month growth (percent) & 23.3 & 28.0 & 20.8 & 0.0 & 4.0 \\
\hline Credit to enterprises & 4,735 & 5,955 & 7,421 & 7,421 & 7,717 \\
\hline 12-month growth (percent) & 20.7 & 25.8 & 24.6 & 0.0 & 4.0 \\
\hline Credit to households (12-month growth, percent) & 26.5 & 30.0 & 17.8 & 0.0 & 4.0 \\
\hline Year-to-date growth of deposits (percent) & 27.4 & 24.3 & 4.2 & 3.6 & 5.6 \\
\hline Year-to-date increase in credit to private sector & 1,747 & 2,593 & 2,461 & 4 & 568 \\
\hline Credit to private sector (percent of GDP) & 48.3 & 54.7 & 58.2 & 58.9 & 59.4 \\
\hline Base for reserves & 12,096 & 15,163 & 16,774 & 17,153 & 17,756 \\
\hline Excess reserves/deposits (in percent) & 13.2 & 13.1 & 6.9 & 9.4 & 9.9 \\
\hline Velocity of deposits & 2.4 & 2.2 & 2.3 & 2.2 & 2.2 \\
\hline
\end{tabular}

Sources: $\mathrm{CBBH}$; and IMF staff estimates. 
Table 9. Bosnia and Herzegovina: Baseline Medium-Term Outlook, 2006-14 1/

\begin{tabular}{|c|c|c|c|c|c|c|c|c|c|c|}
\hline & 2005 & 2006 & 2007 & 2008 & 2009 & 2010 & 2011 & 2012 & 2013 & 2014 \\
\hline & & & & Est. & \multicolumn{6}{|c|}{ Projections } \\
\hline \multicolumn{11}{|l|}{ Real sector } \\
\hline Real GDP growth (percent) & 3.9 & 6.9 & 6.8 & 5.5 & -3.0 & 0.5 & 4.0 & 6.0 & 6.0 & 4.5 \\
\hline $\mathrm{CPI}$, period average percent change & 3.6 & 6.1 & 1.5 & 7.4 & 1.6 & 2.3 & 2.5 & 2.5 & 2.5 & 2.5 \\
\hline & \multicolumn{10}{|c|}{ (In percent of GDP, unless otherwise indicated) } \\
\hline \multicolumn{11}{|l|}{ Savings and investment } \\
\hline Consumption & 113.7 & 108.8 & 107.5 & 108.3 & 105.6 & 103.2 & 100.9 & 99.8 & 99.1 & 98.8 \\
\hline Public & 20.4 & 19.8 & 19.4 & 21.5 & 20.6 & 20.1 & 19.2 & 18.9 & 18.9 & 18.9 \\
\hline Private & 93.3 & 89.0 & 88.1 & 86.9 & 85.0 & 83.1 & 81.6 & 80.9 & 80.1 & 79.8 \\
\hline Investment & 27.4 & 20.9 & 25.0 & 24.4 & 20.2 & 23.1 & 24.8 & 24.9 & 24.7 & 24.5 \\
\hline Public & 6.9 & 6.1 & 6.7 & 6.0 & 7.1 & 7.9 & 8.0 & 7.8 & 7.6 & 7.4 \\
\hline Private & 20.5 & 14.8 & 18.3 & 18.4 & 13.2 & 15.1 & 16.8 & 17.1 & 17.1 & 17.1 \\
\hline National savings & 9.4 & 12.6 & 12.3 & 9.7 & 10.6 & 13.4 & 15.3 & 15.8 & 16.4 & 16.5 \\
\hline Public & 7.6 & 8.2 & 5.1 & 1.2 & 1.5 & 3.1 & 4.3 & 5.3 & 5.8 & 5.9 \\
\hline Private & 1.8 & 4.4 & 7.2 & 8.5 & 9.1 & 10.4 & 11.0 & 10.5 & 10.5 & 10.6 \\
\hline Foreign savings & 18.0 & 8.4 & 12.7 & 14.7 & 9.7 & 9.6 & 9.5 & 9.1 & 8.3 & 8.0 \\
\hline \multicolumn{11}{|l|}{ General government } \\
\hline Total revenue and grants & 45.5 & 47.4 & 47.4 & 45.8 & 45.0 & 45.9 & 45.9 & 45.7 & 46.0 & 46.0 \\
\hline o/w Grants & 3.0 & 2.6 & 3.2 & 2.1 & 2.3 & 3.0 & 3.2 & 3.1 & 3.2 & 3.1 \\
\hline Total expenditure & 44.7 & 45.2 & 47.5 & 49.9 & 49.7 & 49.9 & 48.6 & 47.3 & 46.8 & 46.5 \\
\hline Current & 37.8 & 39.1 & 40.9 & 43.8 & 42.7 & 42.0 & 40.6 & 39.5 & 39.2 & 39.1 \\
\hline Capital & 6.9 & 6.1 & 6.7 & 6.0 & 7.1 & 7.9 & 8.0 & 7.8 & 7.6 & 7.4 \\
\hline Overall balance & 0.8 & 2.2 & -0.1 & -4.0 & -4.7 & -4.0 & -2.7 & -1.5 & -0.8 & -0.5 \\
\hline Overall balance excl. grants & -2.2 & -0.4 & -3.3 & -6.1 & -7.0 & -7.0 & -5.9 & -4.7 & -4.1 & -3.7 \\
\hline Public debt (percent of GDP) 2/ & 25.6 & 22.0 & 29.8 & 27.8 & 34.7 & 39.8 & 40.3 & 38.0 & 34.3 & 30.2 \\
\hline \multicolumn{11}{|l|}{ Balance of payments } \\
\hline Current account balance (percent of GDP) & -18.0 & -8.4 & -12.7 & -14.7 & -9.7 & -9.6 & -9.5 & -9.1 & -8.3 & -8.0 \\
\hline Export growth rate (percent) & 22.8 & 30.5 & 15.0 & 11.6 & -21.4 & 8.4 & 11.9 & 10.4 & 10.3 & 10.1 \\
\hline Import growth rate (percent) & 12.5 & 1.2 & 18.7 & 14.0 & -19.7 & 6.2 & 7.6 & 7.3 & 7.5 & 7.7 \\
\hline \multirow[t]{2}{*}{ Gross reserves (months of imports of GNFS) } & 4.0 & 4.3 & 4.7 & 5.5 & 4.7 & 4.5 & 4.4 & 4.5 & 4.5 & 4.5 \\
\hline & \multicolumn{10}{|c|}{ (In percent of exports of goods and services) } \\
\hline Total external debt service & 9.4 & 11.5 & 8.0 & 8.0 & 11.3 & 12.3 & 12.5 & 11.5 & 11.5 & 13.4 \\
\hline Memorandum item: GDP, millions of KM & 16,928 & 19,121 & 21,640 & 24,545 & 24,298 & 25,036 & 26,657 & 28,991 & 31,494 & 33,726 \\
\hline
\end{tabular}


Table 10. Bosnia and Herzegovina: Gross Financing Requirements 2007-14 (In millions of euros, unless noted otherwise)

\begin{tabular}{|c|c|c|c|c|c|c|c|c|c|}
\hline & & 2007 & 2008 & 2009 & 2010 & 2011 & 2012 & 2013 & 2014 \\
\hline Financing requirements & & 1,718 & 1,986 & 1,411 & 1,471 & 1,545 & 1,606 & 1,707 & 1,908 \\
\hline Current account deficit & & 1,401 & 1,842 & 1,201 & 1,234 & 1,293 & 1,347 & 1,338 & 1,372 \\
\hline Amortization & & 317 & 143 & 211 & 237 & 252 & 259 & 369 & 536 \\
\hline Government, excluding IMF repurchases & & 58 & 60 & 114 & 117 & 123 & 156 & 333 & 491 \\
\hline Other & & 260 & 83 & 97 & 120 & 129 & 103 & 36 & 45 \\
\hline Financing & & 1,718 & 1,986 & 1,411 & 1,471 & 1,545 & 1,606 & 1,707 & 1,908 \\
\hline Capital transfers & & 215 & 202 & 218 & 230 & 242 & 266 & 288 & 311 \\
\hline FDI & & 1,471 & 529 & 258 & 500 & 900 & 990 & 990 & 990 \\
\hline Net bank financing & & -204 & 655 & 82 & 50 & 44 & 173 & 343 & 365 \\
\hline Foreign loans & & 488 & 590 & 210 & 315 & 353 & 377 & 370 & 467 \\
\hline Government & & 285 & 380 & 215 & 245 & 248 & 257 & 220 & 223 \\
\hline Other & & 203 & 210 & -5 & 70 & 105 & 120 & 150 & 244 \\
\hline Gross international reserves $(-=$ increase $)$ & & -637 & 206 & 287 & -75 & -178 & -301 & -261 & -230 \\
\hline Use of Fund credit, net & & -13 & -2 & 0 & 0 & 0 & 0 & 0 & 0 \\
\hline Purchases & & 0 & 0 & 0 & 0 & 0 & 0 & 0 & 0 \\
\hline Repurchases & & -13 & -2 & 0 & 0 & 0 & 0 & 0 & 0 \\
\hline Other & & 386 & -197 & -76 & -111 & -117 & -91 & -24 & 4 \\
\hline Financing gap & & $\ldots$ & $\ldots$ & 433 & 563 & 302 & 191 & 0 & 0 \\
\hline Fiscal & & $\ldots$ & $\ldots$ & 433 & 292 & 35 & 0 & $\ldots$ & $\ldots$ \\
\hline Augmentation of reserves & & $\ldots$ & $\ldots$ & 0 & 271 & 267 & 191 & $\ldots$ & $\ldots$ \\
\hline IMF & & $\ldots$ & $\ldots$ & 305 & 382 & 267 & 191 & $\ldots$ & $\ldots$ \\
\hline in percent of quota & & $\ldots$ & $\ldots$ & 160 & 200 & 140 & 100 & $\ldots$ & $\ldots$ \\
\hline World Bank & & $\ldots$ & $\ldots$ & 103 & 51 & 35 & 0 & $\ldots$ & $\ldots$ \\
\hline EU & & $\ldots$ & $\ldots$ & 0 & 100 & 0 & 0 & $\ldots$ & $\ldots$ \\
\hline Other (including London Club debt deferment) & $1 /$ & $\ldots$ & $\ldots$ & 24 & 30 & 0 & 0 & $\ldots$ & $\ldots$ \\
\hline \multicolumn{10}{|l|}{$\begin{array}{l}\text { Memorandum items: } \\
\text { GDP, millions of euro } \\
\text { IMF quota, millions of eur } \\
\text { In percent of GDP }\end{array}$} \\
\hline & & 2007 & 2008 & 2009 & 2010 & 2011 & 2012 & 2013 & 2014 \\
\hline Financing requirements & & 15.5 & 15.8 & 11.4 & 11.5 & 11.3 & 10.8 & 10.6 & 11.1 \\
\hline Current account deficit & & 12.7 & 14.7 & 9.7 & 9.6 & 9.5 & 9.1 & 8.3 & 8.0 \\
\hline Amortization & & 2.9 & 1.1 & 1.7 & 1.9 & 1.9 & 1.7 & 2.3 & 3.1 \\
\hline Government, excluding IMF repurchases & & 0.5 & 0.5 & 0.9 & 0.9 & 0.9 & 1.0 & 2.1 & 2.8 \\
\hline Other & & 2.3 & 0.7 & 0.8 & 0.9 & 1.0 & 0.7 & 0.2 & 0.3 \\
\hline Financing & & 15.5 & 15.8 & 11.4 & 11.5 & 11.3 & 10.8 & 10.6 & 11.1 \\
\hline Capital transfers & & 1.9 & 1.6 & 1.8 & 1.8 & 1.8 & 1.8 & 1.8 & 1.8 \\
\hline FDI & & 13.3 & 4.2 & 2.1 & 3.9 & 6.6 & 6.7 & 6.1 & 5.7 \\
\hline Net bank financing & & -1.8 & 5.2 & 0.7 & 0.4 & 0.3 & 1.2 & 2.1 & 2.1 \\
\hline Foreign loans & & 4.4 & 4.7 & 1.7 & 2.5 & 2.6 & 2.5 & 2.3 & 2.7 \\
\hline Government & & 2.6 & 3.0 & 1.7 & 1.9 & 1.8 & 1.7 & 1.4 & 1.3 \\
\hline Other & & 1.8 & 1.7 & 0.0 & 0.5 & 0.8 & 0.8 & 0.9 & 1.4 \\
\hline Gross international reserves $(-=$ increase $)$ & & -5.8 & 1.6 & 2.3 & -0.6 & -1.3 & -2.0 & -1.6 & -1.3 \\
\hline Use of Fund credit, net & & -0.1 & 0.0 & 0.0 & 0.0 & 0.0 & 0.0 & 0.0 & 0.0 \\
\hline Purchases & & 0.0 & 0.0 & 0.0 & 0.0 & 0.0 & 0.0 & 0.0 & 0.0 \\
\hline Repurchases & & -0.1 & 0.0 & 0.0 & 0.0 & 0.0 & 0.0 & 0.0 & 0.0 \\
\hline Other & & 3.5 & -1.6 & -0.6 & -0.9 & -0.9 & -0.6 & -0.1 & 0.0 \\
\hline Financing gap & & $\ldots$ & $\ldots$ & 3.5 & 4.4 & 2.2 & 1.3 & $\ldots$ & $\ldots$ \\
\hline Fiscal & & $\cdots$ & $\cdots$ & 3.5 & 2.3 & 0.3 & 0.0 & $\cdots$ & $\cdots$ \\
\hline Augmentation of reserves & & $\ldots$ & $\ldots$ & 0.0 & 2.1 & 2.0 & 1.3 & $\cdots$ & $\ldots$ \\
\hline IMF & & $\ldots$ & $\ldots$ & 2.5 & 3.0 & 2.0 & 1.3 & $\ldots$ & $\ldots$ \\
\hline World Bank & & $\ldots$ & $\ldots$ & 0.8 & 0.4 & 0.3 & 0.0 & $\ldots$ & $\ldots$ \\
\hline EU & & $\ldots$ & $\ldots$ & 0.0 & 0.8 & 0.0 & 0.0 & $\ldots$ & $\ldots$ \\
\hline Other (including London Club debt deferment) & $1 /$ & $\ldots$ & $\ldots$ & 0.2 & 0.2 & 0.0 & 0.0 & $\ldots$ & $\ldots$ \\
\hline
\end{tabular}

Source: IMF staff projections and calculations.

1/ For 2010 , a projection of external financing to be identified by the first program review. 
Table 11. Bosnia and Herzegovina: Indicators of Capacity to Repay the Fund, 2008-14

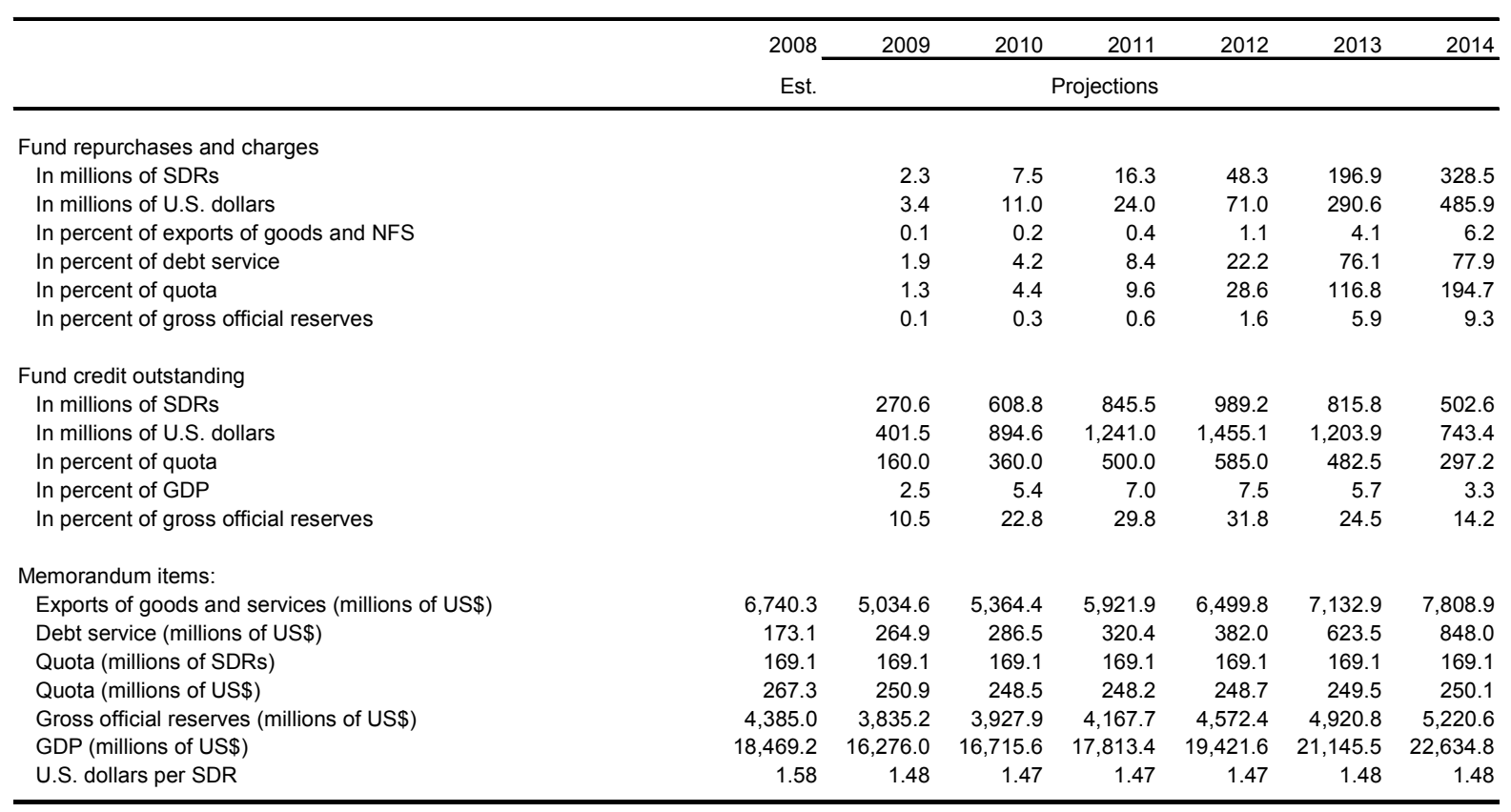

Source: Fund staff estimates. 
Table 12. Financial Soundness Indicators, 2004-08

\begin{tabular}{|c|c|c|c|c|c|c|}
\hline & 2007 & 2008Q1 & 2008Q2 & 2008Q3 & $2008 Q 4$ & $2009 Q 1$ \\
\hline \multicolumn{7}{|l|}{ Capital } \\
\hline Tier 1 capital to risk-weighted assets (RWA) & 12.6 & 13.1 & 12.3 & 11.3 & 12.0 & 12.8 \\
\hline Net capital to RWA & 17.1 & 16.5 & 16.1 & 15.0 & 16.3 & 16.3 \\
\hline \multicolumn{7}{|l|}{ Quality of assets } \\
\hline Nonperforming assets (NPAs) to total assets & 1.8 & 2.0 & 2.0 & 2.0 & 2.2 & 2.3 \\
\hline NPAs net of provisions to tier 1 & 12.9 & 12.7 & 13.1 & 14.6 & 14.3 & 14.0 \\
\hline Nonperforming loans to total loans & 3.0 & 3.1 & 3.0 & 3.0 & 3.1 & 3.3 \\
\hline Provision to NPAs & 37.2 & 37.7 & 38.3 & 37.2 & 37.9 & 38.5 \\
\hline \multicolumn{7}{|l|}{ Profitability } \\
\hline Return on assets & 0.9 & 0.5 & 0.6 & 0.4 & 0.4 & 0.3 \\
\hline Return on equity & 8.9 & 5.0 & 5.5 & 4.7 & 4.3 & 3.4 \\
\hline Net interest income to gross income & 59.9 & 61.0 & 60.7 & 61.4 & 60.6 & 63.3 \\
\hline Noninterest expenses to gross income & 84.9 & 95.0 & 90.4 & 89.4 & 90.5 & 89.6 \\
\hline \multicolumn{7}{|l|}{ Liquidity } \\
\hline Liquid assets to total assets & 37.7 & 34.9 & 32.2 & 31.7 & 30.0 & 29.4 \\
\hline Liquid assets to short- term financial liabilities & 61.3 & 56.7 & 53.5 & 52.8 & 51.8 & 51.8 \\
\hline Short- term financial liabilities to total financial liabilities & 69.0 & 69.3 & 67.7 & 67.0 & 65.4 & 64.3 \\
\hline \multicolumn{7}{|l|}{ Foreign exchange risk } \\
\hline Foreign currency and indexed loans to total loans & 74.0 & 73.0 & 70.3 & 74.5 & 73.3 & 73.0 \\
\hline Foreign currency liabilities to total financial liabilities & 65.0 & 65.7 & 66.5 & 66.7 & 69.5 & 70.1 \\
\hline Net open position & 4.9 & 1.4 & -1.3 & 1.4 & 6.2 & 1.6 \\
\hline
\end{tabular}

Source: CBBH. 


\section{Prior Actions for Board consideration of the arrangement}

1. Adopt rebalanced budgets by Entity governments and submit to Parliaments.

2. Adopt amendments to the wage bill legislation by the State Council of Ministers.

3. Adopt the Intervention Law in the Federation.

4. Adopt the excise law.

5. Adopt the Global Framework by the Fiscal Council

II. Structural Benchmarks

A. Continued adherence to the Currency Board Arrangement as constituted under the law

\section{B. Fiscal Sector}

1. Approve the rebalanced budgets by the Entity Parliaments

2. Agree on an action plan acceptable to the World Bank and IMF staffs to reform the system of rightsbased transfers (Federation)

3. Submit to the Parliament a Law forbidding passing of unfunded legislation (Federation)

4. Publish on the State government's web site quarterly consolidated general government accounts with fiscal transparency; program monitoring and ownership a 5 week lag

\section{Financial Sector}

1. Form the standing committee of financial stability (SCFS) and sign the MoU on financial stability, crisis strengthen financial sector supervision and improve preparedness and crisis management

2. The Deposit Insurance Agency to impose a principle of universal membership requirements, including strengthen banking system stability for partially state-owned banks policy coordination

fiscal adjustment necessary for reestablishment of macroeconomic stability

fiscal adjustment necessary for reestablishment of macroeconomic stability and ongoing viability of the currency board

enable the Federation government to initiate necessary reforms in the near horizon

tax harmonization with EU that will also allow to compensate for some of the revenue loss from phaseout of trade taxes

fiscal policy coordination; reinforce the importance of

adherence to established timeline for budget and

medium-term budget framework elaboration

anchor for macroeconomic policy; contribute to economic and political stability, and investor confidence

continuous

fiscal adjustment necessary for reestablishment of

end-August 2009

ensure fiscal sustainability and improve the composition end-November 2009 of public spending

ensure fiscal discipline

end-November 2009

continuous

end-November 2009

end-February 2010 
Table 14. Bosnia and Herzegovina: Proposed Schedule of Purchases Under the Stand-By Arrangement, 2009-12

\begin{tabular}{cccc}
\multirow{2}{*}{$\begin{array}{c}\text { Available on } \\
\text { or after }\end{array}$} & \multicolumn{2}{c}{ Amount of Purchase } & \\
\cline { 2 - 3 } & $\begin{array}{c}\text { In millions } \\
\text { of SDRs }\end{array}$ & $\begin{array}{l}\text { In percent } \\
\text { of quota 1/ }\end{array}$ & Conditions
\end{tabular}
1. July 8,2009
2. December 10, 2009

3. March 10, 2010

33.82

33.82

135.28

135.28

6. December 10, 2010

7. March 10, 2011

8. June 10,2011

9. September 10, 2011

10. December 10, 2011

11. March 10, 2012

84.55

108.0

52.0

20.0

20.0

80.0

80.0

20.0

12. June 10,2012
84.55

20.0

50.0

50.0

84.55

33.82

84.55

50.0

50.0
Board approval of the arrangement.

Observance of end-September 2009 performance criteria and completion of the first program review.

Observance of end-December 2009 performance criteria, and completion of the quarterly program review.

Observance of end-March 2010 performance criteria and completion of the quarterly program review.

Observance of end-June 2010 performance criteria and completion of the quarterly program review.

Observance of end-September 2010 performance criteria and completion of the quarterly program review.

Observance of end-December 2010 performance criteria and completion of the quarterly program review.

Observance of end-March 2011 performance criteria and completion of the quarterly program review.

Observance of end-June 2011 performance criteria and completion of the quarterly program review.

Observance of end-September 2011 performance criteria and completion of the quarterly program review.

Observance of end-December 2011 performance criteria and completion of the quarterly program review.

Observance of end-March 2012 performance criteria and completion of the quarterly program review.

Total

1/ The quota is SDR 169.1 million. 


\section{Appendix I. Bosnia and Herzegovina: Debt Sustainability Analysis}

\section{Public debt}

1. Under a scenario envisaging fiscal consolidation over the medium term, $\mathrm{BiH}$ 's debt levels appear sustainable, yet sensitive to a number of customized shocks. Continuous fiscal consolidation would stabilize the debt-to-GDP ratio closer to its 2008 level over the medium term. Although the gross financing need increases during 2009-11, lower deficits bring the debt ratios to a sustainable level towards the end of the projection period. This scenario is based on the assumption that fiscal reforms envisaged under the program are implemented along with projected lower outlays on discretionary spending ahead.

2. BiH's public debt is susceptible to shocks. Lower growth, exchange rate depreciation and higher primary deficits would substantially worsen debt sustainability with debt-to GDP ratios increasing between 5 and 18 percentage points by 2014 .

3. An alternative country-specific scenario points sharply-increasing debt levels in the case of a complete lack of adjustment. In this scenario, projected primary balances are kept at their 2008 level in percent of GDP. The gross financing need increases from 31 percent to over 45 percent of GDP. Even in the case such financing is available for $\mathrm{BiH}$, it would have a detrimental effect on debt levels.

\section{External debt}

4. BiH's external debt has improved in the past few years, but increasing external financing needs are projected to increase the debt-to-GDP ratio from about 29.5 percent in 2003 to about 58.0 percent in 2011-12. These developments are driven by an increase in public external debt in response to a worsening of the external environment and limited borrowing opportunities for the private sector. In the baseline scenario, the dynamics of external debt indicators are broadly manageable and consistent with the macroeconomic framework under the SBA. The baseline scenario assumes gradual improvement of debt indicators, in line with the assumptions in the macroeconomic framework.

\section{Bound tests reveal that BiH's external debt remains vulnerable to a number of}

shocks. The tests suggest that BiH's external position is particularly vulnerable to a real depreciation shock, a noninterest current account shock, and a slowdown in GDP growth. An interest rate shock seems to have a relatively moderate impact. For instance, a depreciation of the exchange rate by 30 percent would push external debt to above 70 percent of GDP, though debt would eventually return to a declining path in subsequent years. A negative 
shock on the current account balance would also lead to an unsustainable debt path, with the external debt ratio reaching 67 percent of GDP through $2014 .^{1}$

\section{Managing debt sustainability and reducing the risks of rapid debt accumulation} will depend on maintaining sound macroeconomic policies, solid growth and continuous fiscal consolidation. Dynamics also crucially depends on the assumptions of growth recovery in 2011, current account adjustment in the medium-term and increase in FDI (including privatization).

\footnotetext{
${ }^{1}$ The CAB shock assumes that noninterest current account is at baseline minus one-half standard deviations.
} 


\begin{tabular}{|c|c|c|c|c|c|c|c|c|c|}
\hline & \multicolumn{2}{|c|}{ Actual } & \multicolumn{6}{|c|}{ Projections } & \multirow{3}{*}{$\begin{array}{c}\text { Debt-stabilizing } \\
\text { primary } \\
\text { balance } 9 /\end{array}$} \\
\hline & 2007 & 2008 & 2009 & 2010 & 2011 & 2012 & 2013 & 2014 & \\
\hline \multirow{3}{*}{$\begin{array}{l}1 \text { Baseline: Public sector debt } 1 / \\
\text { o/w foreign-currency denominated }\end{array}$} & & & & & & & & & \\
\hline & 29.8 & 27.8 & 34.7 & 39.8 & 40.3 & 38.0 & 34.3 & 30.2 & -1.1 \\
\hline & 17.6 & 17.1 & 21.5 & 26.3 & 27.8 & 27.5 & 24.7 & 21.5 & \\
\hline & 7.9 & -2.0 & 6.8 & 5.2 & 0.5 & -2.3 & -3.7 & -4.1 & \\
\hline 3 Identified debt-creating flows $(4+7+12)$ & -0.8 & 10.2 & 10.4 & 2.9 & 0.3 & -3.2 & -2.2 & -1.7 & \\
\hline 4 Primary deficit & -0.5 & 3.5 & 3.8 & 3.0 & 1.6 & 0.5 & -0.2 & -0.4 & \\
\hline $5 \quad$ Revenue and grants & 47.4 & 45.8 & 45.0 & 45.9 & 45.9 & 45.7 & 46.0 & 46.0 & \\
\hline Primary (noninterest) expenditure & 46.9 & 49.3 & 48.9 & 49.0 & 47.5 & 46.2 & 45.8 & 45.5 & \\
\hline 7 Automatic debt dynamics $2 /$ & -3.7 & -2.8 & 1.1 & -0.1 & -1.3 & -2.2 & -2.0 & -1.3 & \\
\hline 8 Contribution from interest rate/growth differential 3/ & -1.9 & -3.0 & 1.1 & -0.1 & -1.3 & -2.2 & -2.0 & -1.3 & \\
\hline Of which contribution from real interest rate & -0.6 & -1.6 & 0.3 & 0.1 & 0.1 & 0.1 & 0.1 & 0.2 & \\
\hline Of which contribution from real GDP growth & -1.3 & -1.4 & 0.8 & -0.2 & -1.5 & -2.2 & -2.1 & -1.4 & \\
\hline 11 Contribution from exchange rate depreciation $4 /$ & -1.8 & 0.2 & & $\ldots$ & $\ldots$ & & $\ldots$ & $\ldots$ & \\
\hline 12 Other identified debt-creating flows & 3.4 & 9.5 & 5.4 & 0.0 & 0.0 & -1.5 & 0.0 & 0.0 & \\
\hline $13 \quad$ Privatization receipts (negative) & -7.8 & -0.5 & 0.0 & 0.0 & 0.0 & -1.5 & 0.0 & 0.0 & \\
\hline Recognition of implicit or contingent liabilities & 11.2 & 10.0 & 5.5 & 0.0 & 0.0 & 0.0 & 0.0 & 0.0 & \\
\hline $15 \quad$ Other (specify, e.g. bank recapitalization) & 0.0 & 0.0 & 0.0 & 0.0 & 0.0 & 0.0 & 0.0 & 0.0 & \\
\hline 16 Residual, including asset changes (2-3) $5 /$ & 8.7 & -12.2 & -3.6 & 2.2 & 0.2 & 0.9 & -1.5 & -2.3 & \\
\hline Public sector debt-to-revenue ratio $1 /$ & 62.9 & 60.7 & 77.0 & 86.7 & 87.8 & 83.0 & 74.5 & 65.8 & \\
\hline \multirow{2}{*}{$\begin{array}{l}\text { Gross financing need } 6 / \\
\text { in billions of U.S. dollars }\end{array}$} & 23.3 & 30.1 & 35.1 & 37.5 & 34.9 & 33.1 & 31.2 & 31.1 & \\
\hline & 3.5 & 5.6 & 5.7 & 6.3 & 6.2 & 6.4 & 6.6 & 7.0 & \\
\hline \multirow{2}{*}{$\begin{array}{l}\text { Scenario with key variables at their historical averages } 7 / \\
\text { Scenario with constant primary balance in } 2009-2014\end{array}$} & & & 28.5 & 29.3 & 28.3 & 26.6 & 24.3 & 21.4 & -1.3 \\
\hline & & & 34.7 & 43.5 & 46.6 & 47.7 & 48.1 & 48.4 & -1.8 \\
\hline \multicolumn{10}{|l|}{ Key Macroeconomic and Fiscal Assumptions Underlying Baseline } \\
\hline Real GDP growth (in percent) & 6.8 & 5.5 & -3.0 & 0.5 & 4.0 & 6.0 & 6.0 & 4.5 & \\
\hline $\begin{array}{l}\text { Average nominal interest rate on public debt (in percent) } 8 / \\
\text { Average real interest rate (nominal rate minus change in GDP deflator in percent) }\end{array}$ & 3.2 & 2.0 & 3.0 & 2.8 & 2.9 & 2.9 & 2.8 & 3.1 & \\
\hline \multirow{2}{*}{$\begin{array}{l}\text { Average real interest rate (nominal rate minus change in GDP deflator, in percent) } \\
\text { Nominal appreciation (increase in US dollar value of local currency, in percent) }\end{array}$} & -2.7 & -5.5 & 1.0 & 0.2 & 0.5 & 0.3 & 0.3 & 0.6 & \\
\hline & 10.3 & -1.5 & 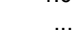 & $\ldots$ & $\ldots$ & $\ldots$ & $\ldots$ & $\ldots$ & \\
\hline \multirow{2}{*}{ Inflation rate (GDP deflator, in percent) } & 5.9 & 7.5 & 2.0 & 2.5 & 2.4 & 2.6 & 2.5 & 2.5 & \\
\hline & 12.5 & 11.0 & -3.9 & 0.7 & 1.0 & 3.0 & 5.2 & 3.8 & \\
\hline $\begin{array}{l}\text { Growth of real primary spending (deflated by GDP deflator, in percent) } \\
\text { Primary deficit }\end{array}$ & -0.5 & 3.5 & 3.8 & 3.0 & 1.6 & 0.5 & -0.2 & -0.4 & \\
\hline
\end{tabular}

1/ General government.

2/ Derived as $[(r-\pi(1+g)-g+\alpha \varepsilon(1+r)] /(1+g+\pi+g \pi))$ times previous period debt ratio, with $r=$ interest rate; $\pi=$ growth rate of GDP deflator; $g=$ real GDP growth rate;

$\mathrm{a}=$ share of foreign-currency denominated debt; and $\varepsilon=$ nominal exchange rate depreciation (measured by increase in local currency value of U.S. dollar).

$3 /$ The real interest rate contribution is derived from the denominator in footnote $2 /$ as $r-\pi(1+g)$ and the real growth contribution as - -9

$4 /$ The exchange rate contribution is derived from the numerator in footnote $2 /$ as $\alpha \varepsilon(1+r)$

$5 /$ For projections, this line includes exchange rate changes.

(Defined as public sector deficit plus amortization of medium and long-term public sector debt, plus short-term debt at end of previous period.

7/ The key variables include real GDP growth; real interest rate; and primary balance in percent of GDP.

nominal interest expenditure divided by previous period debt stock.

9/ Assumes that key variables (real GDP growth, real interest rate, and other identified debt-creating flows) remain at the level of the last projection year. 
Figure 1. Bosnia and Herzegovina: Public Debt Sustainability: Bound Tests 1/ (Public debt in percent of GDP)
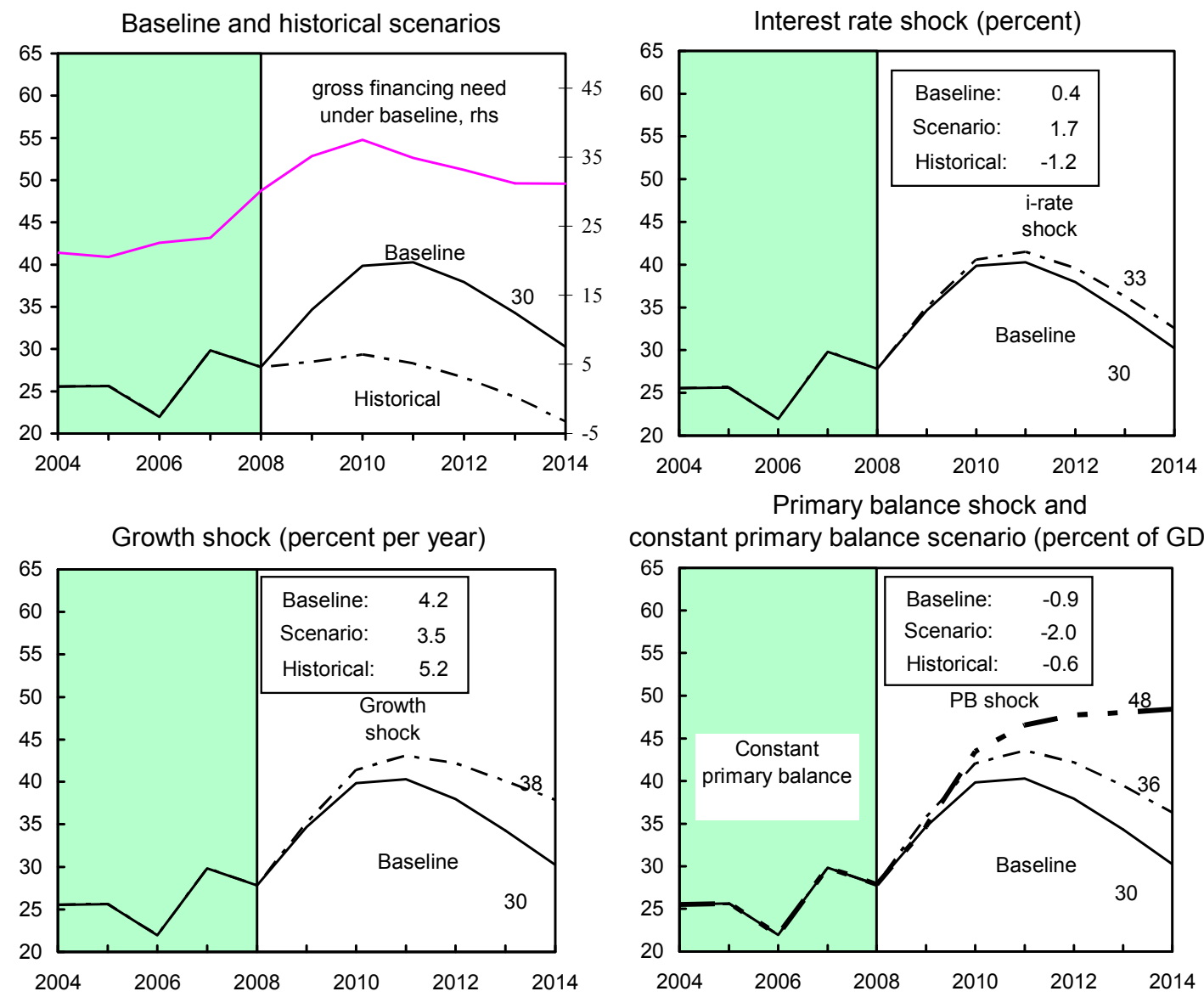

constant primary balance scenario (percent of GDP)

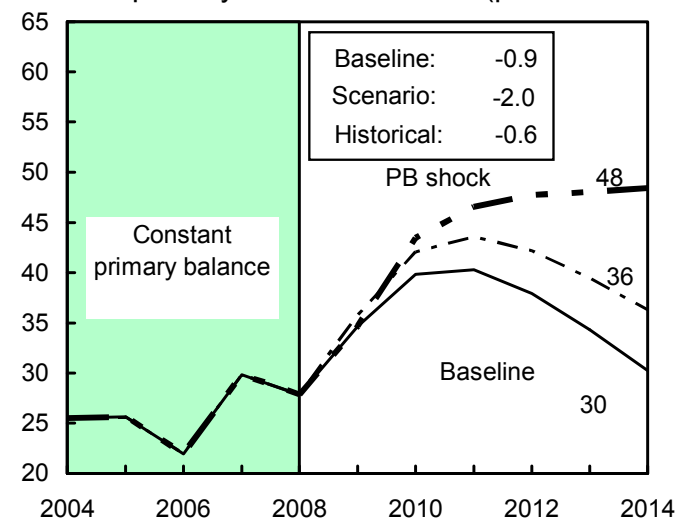

Combined shock 2/

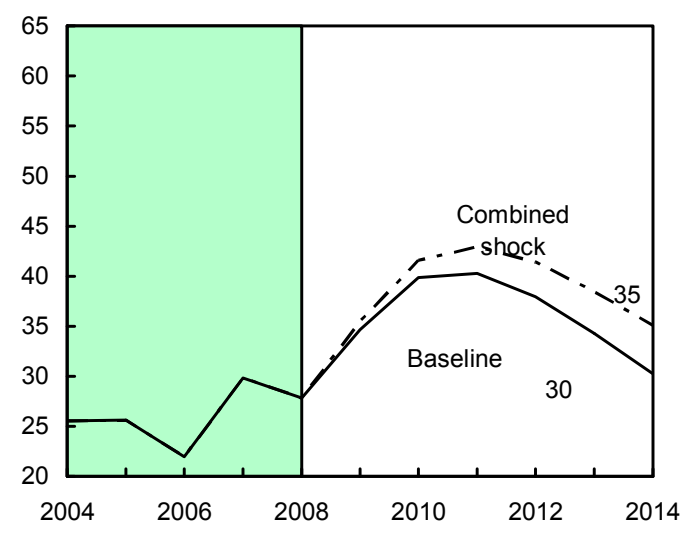

Real depreciation and contingent liabilities shocks $3 /$

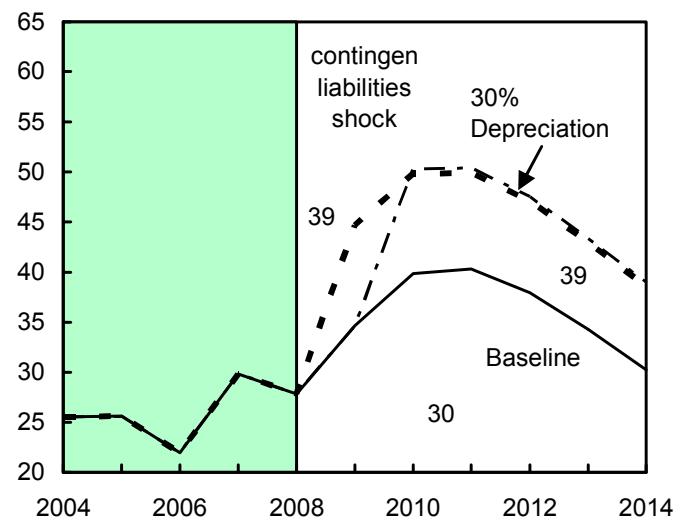

Sources: International Monetary Fund, country desk data, and staff estimates.

1 / Shaded areas represent actual data. Individual shocks are permanent one-half standard deviation shocks. Figures in the boxes represent average projections for the respective variables in the baseline and scenario being presented. Ten-year historical average for the variable is also shown.

2/ Permanent 1/4 standard deviation shocks applied to real interest rate, growth rate, and primary balance.

$3 /$ One-time real depreciation of 30 percent and 10 percent of GDP shock to contingent liabilities occur in 2009 , with real depreciation defined as nominal depreciation (measured by percentage fall in dollar value of local currency) minus domestic inflation (based on GDP deflator). 
Table 2. Bosnia \& Herzegovina: External Debt Sustainability Framework, 2005-2013

(In percent of GDP, unless otherwise indicated)

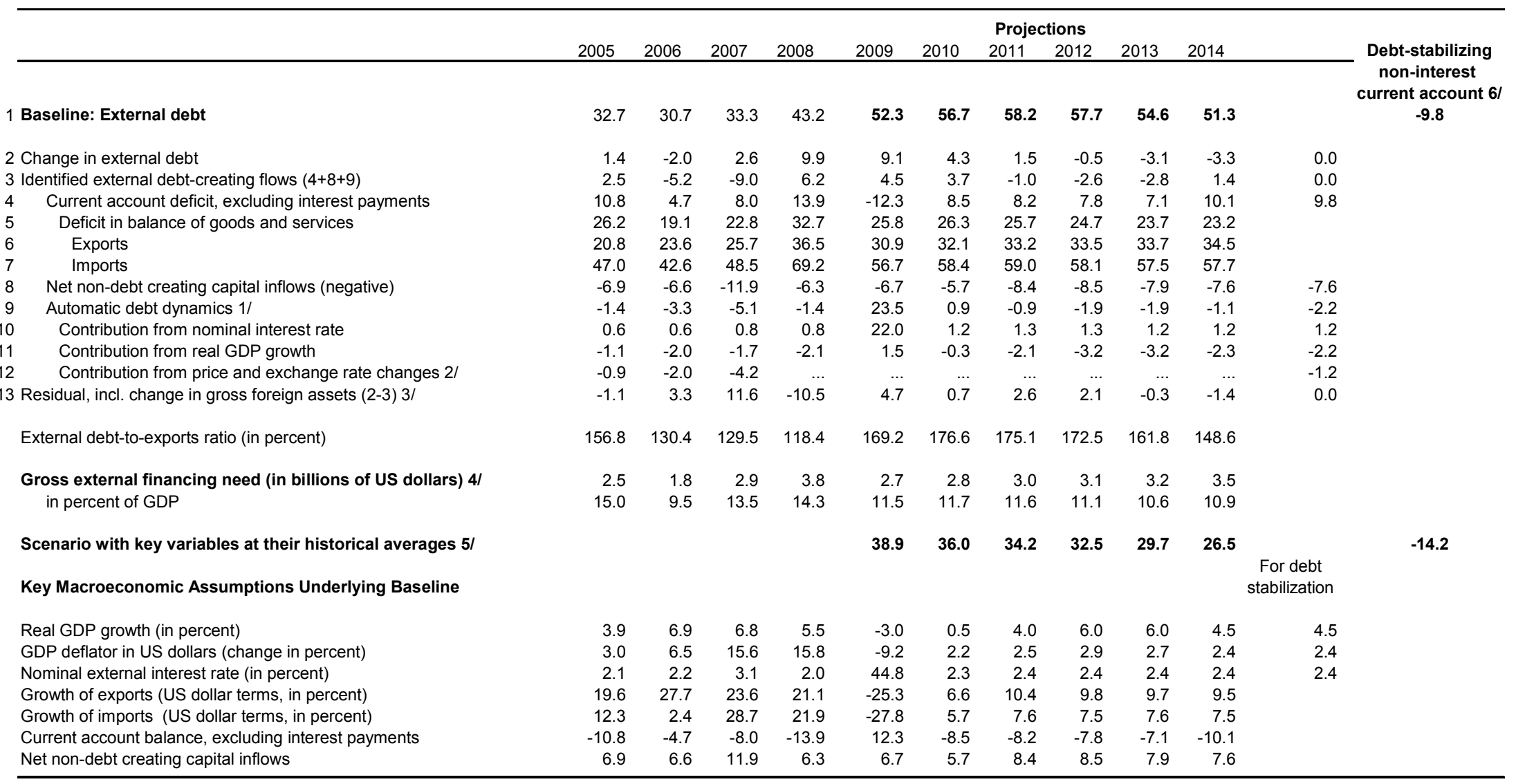

$1 /$ Derived as $[r-g-\rho(1+g)+\varepsilon \alpha(1+r)] /(1+g+\rho+g \rho)$ times previous period debt stock, with $r=$ nominal effective interest rate on external debt; $\rho=$ change in domestic GDP deflator in US dollar terms, $g=$ real GDP growth rate, $\varepsilon=$ nominal appreciation (increase in dollar value of domestic currency), and $\alpha=$ share of domestic-currency denominated debt in total external debt.

$2 /$ The contribution from price and exchange rate changes is defined as $[-\rho(1+g)+\varepsilon \alpha(1+r)](1+g+\rho+g \rho)$ times previous period debt stock. $\rho$ increases with an appreciating domestic currency $(\varepsilon>0)$ and rising inflation (based on GDP deflator).

3/ For projection, line includes the impact of price and exchange rate changes.

4/ Defined as current account deficit, plus amortization on medium- and long-term debt, plus short-term debt at end of previous period.

5/ The key variables include real GDP growth; nominal interest rate; dollar deflator growth; and both non-interest current account and non-debt inflows in percent of GDP.

6/ Long-run, constant balance that stabilizes the debt ratio assuming that key variables (real GDP growth, nominal interest rate, dollar deflator growth, and non-debt inflows in percent of GDP) remain at their levels

of the last projection year.

\section{CInternational Monetary Fund. Not for Redistribution}


Figure 2. Bosnia \& Herzegovina: External Debt Sustainability: Bound Tests 1/ (External debt in percent of GDP)
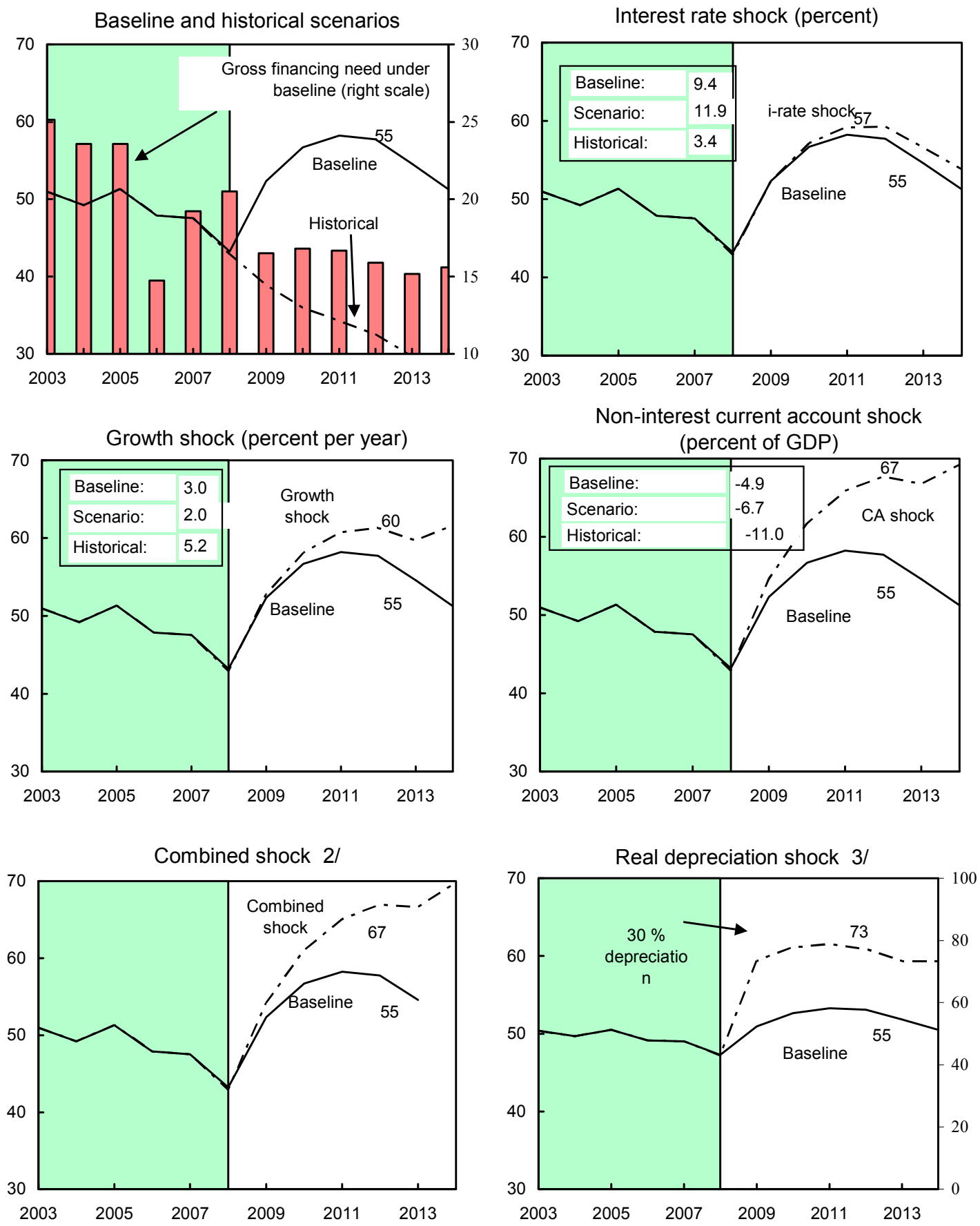

Sources: International Monetary Fund, Country desk data, and staff estimates.

$1 /$ Shaded areas represent actual data. Individual shocks are permanent one-half standard deviation shocks. Figures in the boxes represent average projections for the respective variables in the baseline and scenario being presented. Ten-year historical average for the variable is also shown.

2/ Permanent 1/4 standard deviation shocks applied to real interest rate, growth rate, and current account balance.

3/ One-time real depreciation of 30 percent occurs in 2009. 


\section{Attachment I. Bosnia and Herzegovina: Letter of Intent}

Sarajevo and Banja Luka, Bosnia and Herzegovina

June 16, 2009

Mr. Dominique Strauss-Kahn

Managing Director

International Monetary Fund

Washington, D.C. 20431

Dear Mr. Strauss-Kahn:

1. The global financial and economic crisis has taken its toll on the economy of Bosnia and Herzegovina ( $\mathrm{BiH})$. The impact of the crisis has been aggravated by underlying imbalances in our economy, thus raising concerns about macroeconomic stability and BiH's long-term prospects. In response, the State, Federation, and Republika Srpska governments and the Central Bank of Bosnia and Herzegovina have developed a comprehensive strategy aimed at ensuring continued macroeconomic stability, and supporting our goal for sustainable growth over the medium term. In support of these policies and based on our balance of payments needs, we request that the IMF support our program through a Stand-By Arrangement (SBA) in the amount equivalent to SDR 1.01 billion (600 percent of quota) for the period July 2009 through June 2012.

2. We have discussed with IMF staff our economic program, which is outlined below. The program's objective is to safeguard the continued strength of the Currency Board Arrangement (CBA) and cushion the effects of the deteriorating external environment, while adopting policies to address fiscal imbalances and strengthen the financial sector. We expect the program to help set the stage for sustainable growth and convergence with the EU. To achieve the program's objectives, we intend to:

(i) strengthen fiscal policy to reduce the government's financing needs and improve medium-term fiscal sustainability; (ii) exercise public sector wage restraint; (iii) undertake structural fiscal reforms aimed at reforming the system of transfers and strengthening public finance management; (iv) adopt a coordinated approach to ensure financial sector stability; and (v) promote other structural reforms that would safeguard competitiveness and ensure the stability of the CBA.

3. We have already taken a number of measures to deal with the impact of the crisis. The Central Bank of Bosnia and Herzegovina (CBBH) reduced reserve requirements to 
improve the liquidity situation in the banking sector; the deposit insurance limit was raised substantially; and our governments approved mitigating strategies and have been exercising spending restraint. We realized that the rapidly deteriorating external and financial environment could pose difficulties in the months ahead, and, thus, we have approached the IMF for support. As part of our commitments to the program, we plan to consolidate our public finances - which in recent years saw a significant deteriorationand reorient public spending toward capital investment and to encourage private investment. To protect vulnerable groups, we are going to reform the social safety net. We are also taking measures to ensure sufficient liquidity of the banking sector and to strengthen our crisis preparedness efforts.

4. The program will be monitored through quantitative performance criteria and structural benchmarks, during quarterly reviews. Table 1 below sets out specific quarterly targets that are to be observed under the SBA for: the cumulative change in the banking system net credit to the government and sub-ceilings for the State, the Federation and the Republika Srpska governments; ceiling on new short-term external credit to the State, the Federation and the Republika Srpska governments; ceiling on issuance of new guarantees and on the assumption of enterprise debt to banks by the State, Federation and the Republika Srpska governments; ceiling on accumulation of external and domestic arrears by the State, Federation and the RS governments. Prior actions and structural benchmarks are set out in Table 2. The first review of the program will take place on or after December 10, 2009, and the second review on or after March 10, 2010. The understandings between us and the IMF staff regarding performance criteria and structural measures described in this letter are further specified in the attached Technical Memorandum of Understanding (TMU).

5. We believe that the policies described in this letter are adequate to achieve the objectives of our economic program, but we stand ready to take additional measures as appropriate to ensure the attainment of these objectives. During the period of the arrangement, we will consult with the Fund on the adoption of any new measures and in advance of the policies contained in this letter in accordance with the IMF's policies on such consultations. Further, we will provide the Fund with such information as it requests on policy implementation and achievement of the program objectives.

\section{Recent Economic Performance and Macroeconomic FRAMEWORK FOR 2009-10}

6. The economy of Bosnia and Herzegovina exhibited robust growth in recent years, but over time macroeconomic imbalances emerged. Benefiting from a favorable external environment, the currency board, and the effect of past reforms, real growth averaged 6 percent annually between 2003 and 2008. Fiscal consolidation in 2002-03, a successful introduction of the VAT in 2006, and the recent income tax reforms, as well as major 
privatization completed in Republika Srpska (RS) in 2007, helped improve the health of public finances. Moreover, the establishment of the Fiscal Council in 2008 represents an important step in advancing national fiscal policy coordination. The business climate improved, attracting large inflows of foreign capital, mainly in the form of FDI and foreign bank financing. All these achievements culminated in the signing of the Stabilization and Association Agreement (SAA) with the European Union in June 2008. However, over time, these external inflows fuelled a domestic demand boom: bank credit growth reached 30 percent and the fiscal stance was relaxed in 2008. Reflecting mainly food and energy price shocks, inflation peaked in July 2008; wage growth accelerated; and the external balance worsened.

7. The global economic and financial crisis is now making the transition from the overheated economy appear particularly sharp. With the recession deepening in Europe, export growth stalled in late 2008 and turned negative in 2009. Credit growth has ground to a halt, effectively choking off domestic demand. As a result, imports and indirect tax revenue collections are falling; the latter are also affected by the reduction in customs tariffs as stipulated in the SAA.

8. Through our prompt action we have tried to address the impact of the crisis. The CBBH has relaxed reserve requirements in several steps, most recently in April, and the deposit insurance limit was raised from KM 7,500 to KM 20,000 in late 2008. Faced with revenue shortfalls relative to their projected amounts, our governments have been taking steps to restrain spending relative to the initial budgets. However, the rapidly deteriorating external and financial environment create substantial external and budget financing needs, thus necessitating a rapid adjustment.

9. In view of the uncertain global environment, our program's macroeconomic framework incorporates cautious assumptions. The economy has turned sharply down in recent months, and we expect the global growth slowdown and tighter external financing conditions to weight on BiH's growth outlook in the period ahead. We anticipate a drop in GDP this year of about 3 percent, and hope that the measures proposed in this program will limit the fall. A slow recovery is expected in 2010, but growth is likely to remain near zero. With credit to the economy unlikely to increase, domestic demand will fall sharply, thus contributing to a subsiding of inflationary pressures, with projected CPI inflation of about 2 percent on average during 2009-10.

10. A fast contraction in imports will contribute to a narrowing in the external current account deficit this year, thus reducing our gross external financing needs in 2009. However, there will also be a reduction in available capital inflows. We expect that foreign parent banks will maintain their exposure to their BiH subsidiaries. The remaining external financial needs can be covered by drawing on resources, mainly from the IMF, and also from the World Bank, the EU, and bilateral contributions. 


\section{ECONOMIC Policies}

11. We recognize that a strong policy package will be required to achieve our goals. Since the overarching objective of the program is to safeguard the continued strength of the currency board and cushion the effects of the deteriorating external environment, the burden of the adjustment will fall primarily on fiscal and incomes policies. We are convinced that the fiscal consolidation and public sector wage restraint outlined below will ensure stability in the short term, but also bring us back to the path of fiscal sustainability. Fiscal policy measures will be accompanied by measures to strengthen the financial sector and ambitious structural reforms to improve public finance management, and the competitiveness of our economy, thus providing an environment conducive to robust private sector activity.

\section{A. The Currency Board}

12. The Currency Board Arrangement has served us well over the past 12 years and its continued stability remains a key objective of our program. The CBA has ensured macroeconomic stability with low inflation, and has broad political and public support. Thus, we will continue to maintain the strict CBA now in place during the program period. Under this arrangement, the $\mathrm{CBBH}$ is prohibited from extending credit to the government, from issuing central bank securities, and from granting credit to banks and other private agents, through the purchase of securities. Further changes in minimum reserve requirements will be undertaken only after consultation with IMF staff. We do recognize that sizeable exchange rate depreciations in BiH's regional trading partners could nevertheless have adverse implications for the CBA's viability. Thus, we are committed to use all our tools to safeguard competitiveness, including through wage flexibility, implementation of strong macroeconomic and financial sector policies, and progress on structural reform.

\section{B. Fiscal Policy}

13. On account of a sharp increase in spending and weak indirect revenue performance, the fiscal stance worsened in 2008. Increases in wages and higher spending on rights-based transfers, coupled with increasing VAT refunds and lower customs revenues, resulted in a deficit of 4 percent of GDP in 2008, from a near balance in 2007. We are aware that under past spending trends and current revenue performance, the consolidated general government deficit could reach 7.8 percent of GDP in 2009. Besides difficulties in financing such a deficit, the increasing fiscal imbalances could threaten medium-term fiscal sustainability.

14. We are committed to maintaining fiscal prudence and we will make strong efforts to limit the 2009 general government deficit to 4.7 percent of GDP. Accordingly, we will prepare rebalanced budgets at the central Entity level of government, which will 
incorporate all our fiscal policy commitments included in this Letter, and have those budgets approved by governments and submitted to Parliaments by end-June 2009 (prior action). We expect the rebalanced budgets to be adopted by Parliaments by end-August (structural benchmark). The Council of Ministers of BiH Institutions will adopt necessary amendments to wage bill legislation and decrees by end-June 2009 (prior action). We recognize that there are several risks to our budgets, and we stand ready to take compensatory measures, if needed.

15. Our adjustment efforts will focus on controlling current expenditure, thus allowing space for spending on much-needed infrastructure. We recognize that wages in the public sector have grown very rapidly over the past few years and we are committed to wage restraint across all levels of government. Also, the Federation government recognizes the need to reduce nontargeted transfers to individuals.

16. On the revenue side, we have prepared a draft Law, harmonized with EU legislation, increasing excises on tobacco, coffee and petroleum products. The draft is now under consideration by Parliament and will become effective on July 1, 2009 (prior action), with an estimated impact of KM 162 million— 0.7 percent of GDP—in 2009.

17. On the expenditure side:

The State government has already adopted restrictive measures and will further reduce: spending on wages, meal and vacation allowances, and on good and services to achieve a total expenditure reduction of KM 40 million $(0.2$ percent of GDP). Similar measures will lead to expenditure savings of KM 10 million in the Brcko District.

- In the Federation, the government has passed a restrictive budget for 2009 and has demonstrated restraint in spending, at all levels of government and across all types of expenditures, already in the first quarter of the year. We have also prepared an Intervention Law, to be adopted by the Federation Government by end-May 2009, mandating savings on wages, allowances, transfers and other current expenditures for the duration of the program, and until new legislation reforming spending in these categories is designed and adopted. The Intervention law sets a 10 percent cut compared to the level in December 2008 of the following expenditures: wages of all budget users; transfers to civil and war invalids, and medal holders; transfers for favorable military pensions; transfers to civil victims of war; and all remaining current expenditures.

In addition, the Law introduces a ceiling of 1 percent of the average wage on meal allowances; lowers the vacation allowance to 50 percent of the average wage from 75 percent of the individual wage; and suspends the allowances for participation 
in commissions, overtime work and contractual services. Moreover, savings are envisaged by the cantons, social funds and municipalities. The expected total savings amount to KM 414 million (1.7 percent of GDP) in the Federation.

- In the RS, the central government will reduce spending on: (i) employee compensation, by reducing the salaries of the highest paid civil servants by 10 percent, lowering the daily allowance for business trips, unifying the rulebook on compensations, and adopting a hiring freeze for the entire year; (ii) veteran and disability benefits, by streamlining eligibility criteria and improving targeting; and (iii) current as well as nonproductive capital spending. The expected savings amount to KM 66 million (0.3 percent of GDP).

RS municipalities and extra budgetary funds will also contribute to the adjustment through savings on wages, pensions and other current spending. Expenditure cuts in the municipalities will amount to KM 25 million, and in the health funds to KM 30 million (entirely on wages). In the municipalities, a wage law will be adopted. Finally, through our ongoing ambitious and comprehensive reform of the PAYG pension system, we will be able to save about KM 25 million thanks to the introduction of parametric changes redefining early retirement requirements and introducing a change in the indexation in line with the Swiss model.

18. A strict wage policy across the entire public sector is critical for fiscal consolidation to safeguard external competitiveness. Thus, we are committed to a cautious wage policy for the duration of the program. In addition, we will secure commitments from the boards of all publicly-owned enterprises to restrain spending on wages and other forms of compensation. We expect that wage restraint in the public sector will provide a strong signal for wage moderation in private sector settlements.

19. All governments are committed to maintaining fiscal discipline over the medium term. We therefore intend to continue budget consolidation in 2010, through a further reduction in the consolidated general government deficit to around 4 percent of GDP. Fiscal efforts will continue to be concentrated on the expenditure side, which will benefit from the full-year impact of the reforms undertaken this year. Specific quarterly targets for 2010 will be set at the time of the first review of the program - to be completed by December 31, 2009.

20. We are planning comprehensive structural fiscal reforms to return public finances to a sustainable path. Specifically:

- Following the establishment of the Fiscal Council last year, we intend to strengthen its operational framework. As a first step, the FC will adopt the "Global Framework of fiscal balance and policies in Bosnia and Herzegovina" 
(prior action) and by end-September 2009 revised macroeconomic parameters. This Framework will provide the basis for the preparation of the budgets of the State and the Entities for 2010 and will take into consideration the 2009 savings achieved under this Letter. In the context of the Fiscal Council and with the objective of a more coordinated fiscal policy across the country, we will also set up procedures for improved multi-year budgeting of the various levels of government.

- $\quad$ The Federation government will undertake a comprehensive reform of its rightsbased benefits system, in consultation with the World Bank. We understand that making reforms of the current complex system will take time; and we intend to phase out the revision of the various laws over the next 18 months. As a first step, by end 2009, we intend to: (i) eliminate special unemployment benefits granted to demobilized soldiers by allowing the sunset clause to expire; (ii) introduce a maximum income threshold for eligibility for civilian and veterans benefits; (iii) reduce all civilian and veterans' benefits by 10 percent and eliminate indexation; and (iv) reform war veterans' pensions. These reforms will entail the revision of existing legislation, including: (i) Decree on eligibility for pension under more favorable conditions of the military insurees of the Army of $\mathrm{FBiH}$; (ii) Decree on eligibility for age pension under more favorable conditions of the military insurees of the Army of $\mathrm{FBiH}$; and (iii) Decree on eligibility for age pension under more favorable conditions of the members of the former Army of $\mathrm{FBiH}$ and civil servants and employees of the former Ministry of Defense of FBiH.

- $\quad$ Over the medium term, we will seek the assistance of the World Bank to undertake a comprehensive income and property census and introduce meanstesting for all civilian and war-related benefits.

- The Federation government will establish a centralized system of registration, control, and collection of taxes and social contributions. This should help improve compliance.

- $\quad$ Our governments recognize the importance of further reforming public administration. To this end, we will launch a comprehensive review of the various functions and responsibilities, with the objective of strengthening the quality and efficiency of public administration.

- Along with the objective to provide a more efficient public administration, the Federation government will adopt a comprehensive wage law, which, among others, will aim at consolidating all allowances and bonuses into the main wage. 
- $\quad$ The Federation government recognizes the need to amend the budget process to ensure that approved legislation is backed by sufficient financial resources. To this end, we will work towards adopting a fiscal responsibility law.

- The Federation government is determined to move ahead with the privatization of state-owned companies, and to this end, by June 2009 it will initiate the process.

21. We understand that our adjustment program may have an impact on the vulnerable groups of our population. Thus, we will reform the social safety net to ensure the protection of the poor.

\section{Financial Sector Policies}

22. Our banking system is strong, but we recognize that it faces difficult and uncertain macroeconomic and global financial conditions. All banks are relatively well-capitalized, and most of them (accounting for about 95 percent of total assets) are foreign owned and have parents in the euro area. However, the worsening of global financial situation poses exceptionally uncertain prospects: with credit growth coming to a halt and higher funding costs, bank profitability is deteriorating. This necessitates coordinated action, including support of parent banks and home country authorities. To this end, following the stafflevel agreement on this program, we will seek a pledge from foreign banks to maintain exposure to their $\mathrm{BiH}$ subsidiaries and to recapitalize those as needed over the program period. Finally, we will consult with Fund staff prior to the introduction of any new or revised prudential regulations for banks.

23. The financial sector strategy will evolve around a comprehensive framework to strengthen the financial system and improve monitoring. To this end, the Fiscal Council, the CBBH, the two banking agencies, and the Deposit Insurance Agency (DIA) will form a Standing Committee for Financial Stability (SCFS) and formalize the cooperative arrangements for financial stability, crisis preparedness and management through the signing of a Memorandum of Understanding (MoU). The $\mathrm{CBBH}$ and two banking agencies will produce and monitor high-frequency data; on the basis of such data, regular reports will be prepared and disseminated within the SCFS.

24. As part of our contingency planning in the case of crisis, we intend to strengthen the bank resolution framework, by: (i) preparing a contingency manual for a two-agency bank resolution strategy, (ii) making law amendments to broaden the banking supervisory agencies' discretion to appoint a temporary administrator, and (iii) ensuring irreversibility of supervisors' decisions and seniority of the DIA's claims for depositor reimbursements over the claims of general creditors.

25. To ensure continued confidence in the deposit insurance scheme, we plan to bring the coverage more closely in line with neighboring countries and prospective 
requirements under EU directives. We also intend to supplement the existing Deposit Insurance Fund (DIF) with access to a credit line from EBRD, expected to be approved by June 2009. The DIA will establish a principle of universal membership by abolishing the criteria regarding limits to public ownership of capital and ensuring the consistency between the DIA's membership criteria and banking licensing.

\section{Other}

26. We recognize the importance of improving the quality of statistics, particularly in the context of the IMF program. The State and Entity Statistics Agencies commit to further harmonize the expenditure and production GDP data and publish it in a timely manner. Furthermore, the Statistic Agencies will develop quarterly / semiannual GDP data.

27. This program provides us an opportunity to strengthen our efforts for improving the quality of fiscal statistics, with the objective of compiling data harmonized with Eurostat and the IMF's Government Statistics guidelines. We will ensure timely submission of all fiscal statistics by lower levels of government in the two entities and improve coverage. To this end, and under the umbrella of the Fiscal Council, we will create a coordinating group with the task of collecting and consolidating the fiscal statistics from all levels of government in $\mathrm{BiH}$. This group will consist of officials from the State, Federation, and RS Ministries of Finance, representatives from MAU, and of the Statistics Division of the CBBH.

28. We will broaden the coverage of reporting on fiscal execution to include foreignfinanced projects and off-budget spending from escrow accounts in general government fiscal accounts (State and two entities). Also, we will improve centralized data compilation and monitoring of foreign grants for all levels of government.

29. Because of current general government data weaknesses, the program monitoring relies on changes in net general government position as reported by the central bank. It is envisaged that with improvements in fiscal data reporting the general government position would be ultimately monitored from above the line, as a difference between revenue and expenditure.

30. We recognize the importance of completing a safeguards assessment by the first review of the Stand-By Arrangement. In this regard, the CBBH will provide as soon as feasible the necessary documentation required to complete the assessment by the first review and receive a safeguards mission from the IMF as necessary. IMF resources under the arrangement, in the context of a balance of payments need, will be disbursed to the Central Bank of Bosnia and Herzegovina. 
$/ \mathrm{s} /$

Nikola Špirić

Chair

of the Council of Ministers

Bosnia and Herzegovina

$/ \mathrm{s} /$

Dragan Vrankić

Minister of Finance

of $\mathrm{BiH}$ Institutions

Bosnia and Herzegovina

$/ \mathrm{s} /$

Kemal Kozarić

Governor

Central Bank of Bosnia and Herzegovina
$/ \mathrm{s} /$

Nedžad Branković

Prime Minister

Federation of Bosnia

and Herzegovina

/s/

Vjekoslav Bevanda

Minister of Finance

Federation of Bosnia

and Herzegovina
Milorad Dodik

Prime Minister

Republika Srpska

/s/

Aleksandar Džombić

Minister of Finance

Republika Srpska

Attachments 


\section{Attachment II. Technical Memorandum of Understanding}

\section{BOSNIA AND HERZEGOVINA}

\section{Technical Memorandum of Understanding on Definitions and Reporting Under the 2009-12 Economic Program}

June 16, 2009

This memorandum sets out the understanding between the government of Bosnia and Herzegovina and the IMF mission regarding the definitions of quantitative and structural performance criteria and targets for the stand-by arrangement (Tables 1 and 2) as well as data reporting requirements for program monitoring.

\section{Definitions}

In the following definitions, the end-quarter test dates apply to the last working day of each quarter for both banking and budgetary statistics.

\section{A. Ceiling on the Cumulative Change in Net Credit from the Banking System to the General Government}

\section{Definitions:}

- The general government is defined to include the governments of the State, the Republika Srpska Entity (RS), the Federation of Bosnia and Herzegovina Entity (Federation) and the District Brcko. The Federation government is defined to include the central government, the cantonal governments, the municipal governments, the extrabudgetary funds and the road fund. The RS government is defined to include the central government, the municipal governments, the extrabudgetary funds and the road fund. Extrabudgetary funds include, but are not limited to, the pension funds, health funds, unemployment funds, and children's fund in the two Entities.

- The banking system consists of the Central Bank of Bosnia and Herzegovina (CBBH) and the commercial banks in both Entities and the District of Brcko.

- Net credit to the general government is defined as all claims on general government (e.g. loans, securities, bills, and other claims in both convertible marka and foreign currencies) minus general government claims on the banking system (deposits, loans and other claims, including deposits in entities' escrow accounts). For program 
purposes, those components of claims that are denominated in foreign currencies will be converted into convertible marka at current exchange rates.

\section{Application of performance criteria:}

- The value of banking system net credit to the general government will be monitored from the accounts of the banking system, as compiled by the $\mathrm{CBBH}$, and supplemented by information provided by the Ministries of Finance of each Entity and the State.

- The ceilings on the cumulative change in net credit from the banking system to the general government will be defined, for each test date, as the cumulative change from the level existing on December 31 of the previous year.

- The ceilings on the cumulative change in net credit from the banking system to the general government will be defined in terms of three-sub-ceilings that sum to the ceiling for the general government. These sub-ceilings will be on the cumulative change in net credit from the banking system to the government of the State, the governments of the Federation of Bosnia and Herzegovina and of the Republika Srpska. For the purposes of program monitoring, compliance with the ceiling on banking system net credit to general government will require that each of these three sub-ceilings be observed independently.

\section{B. Operation of the Central Bank of Bosnia and Herzegovina}

Under the Central Banking Law and the program, the $\mathrm{CBBH}$ is required to ensure that the value of its domestic liabilities does not exceed the convertible marka counter-value of its net foreign exchange reserves. Furthermore, the $\mathrm{CBBH}$ will not pay a dividend unless its capital and reserves exceeds 10 percent of its monetary liabilities.

\section{Definitions:}

- Net foreign exchange reserves are defined as the value of foreign assets less the value of foreign liabilities, including assets and liabilities denominated in convertible currencies or convertible marka.

- Foreign assets are defined to include: (i) gold, and other precious metal and stones; (ii) convertible foreign exchange notes; (iii) credit balances in convertible foreign exchange - including SDRs — on the books of foreign central banks or other financial institutions; (iv) liquid debt securities issued by the government and the central bank of the country on whose currency the securities are denominated; and (v) officially 
guaranteed forward and repurchase contracts of different types providing for future payments in convertible foreign exchange by nonresidents.

- Foreign liabilities are defined to include: (i) foreign exchange and convertible marka balances on the books of the CBBH due to nonresidents, including foreign central banks and international financial institutions; (ii) credit balances due to foreign central banks, governments, international organizations, and foreign financial institutions; (iii) forward and repurchase contracts of different types providing for future payments in foreign exchange by the $\mathrm{CBBH}$ to nonresidents; and (iv) any other liabilities due to nonresidents.

- Monetary liabilities are defined as the sum of (a) currency in circulation; (b) credit balances of resident banks at the $\mathrm{CBBH}$; and (c) credit balances of other residents at the $\mathrm{CBBH}$.

- Capital and reserves are defined as (a) initial capital and reserves of the $\mathrm{CBBH}$; (b) shares; and (c) accumulated profits of the $\mathrm{CBBH}$ since the beginning of its operation on August 11, 1997.

- Free reserves of the $\boldsymbol{C B B H}$ are defined as foreign exchange reserves not utilized as backing for the currency. They therefore consist of the stock of CBBH net foreign exchange reserves less the stock of $\mathrm{CBBH}$ monetary liabilities.

- Foreign currency holdings will be converted into convertible marka at the exchange rates of April 30, 2009, as published in the IMF International Financial Statistics. Valuation changes will therefore be monitored from the accounts of the $\mathrm{CBBH}$, with information on net foreign assets provided monthly by the $\mathrm{CBBH} .^{3}$

\section{Ceiling on External Payment Arrears}

\section{Definitions:}

- External payment arrears are defined as overdue debt service arising in respect of debt obligations incurred directly or guaranteed by the general government, except on debt subject to rescheduling or restructuring.

\footnotetext{
${ }^{3}$ At end-April 2009, one SDR unit was equal to 1.1283 euro, or to 1.4978 U.S. dollars.
} 
- Debt obligations are defined as all current liabilities, which are created under a contractual arrangement through the provision of value in the form of assets (Including currency) or services, and which require the general government to make one or more payments in the form of assets (including currency), at some future point(s) in time to discharge principal and/or interest liabilities incurred under the contract. In effect, all instruments that share the characteristics of debt as described above (including loans, suppliers' credits and leases) will be included in the definition and be subject to the ceiling. The definition of general government is as described above.

\section{Application of performance criteria:}

- The ceiling on the change in external payments arrears applies to the change in the stock of overdue payments on medium- and long-term debt contracted or guaranteed by the State, the Federation, and the Republika Srpska. This criterion will apply continuously.

- The limit on the change in external payments arrears also applies to the change in the stock of overdue payments on short term debt in convertible currencies with an original maturity of up to and including one year. The limit excludes reductions in connection with rescheduling of official and commercial debt and debt buy back. Accumulation of new external arrears is prohibited under the program.

\section{Ceiling on Domestic Expenditure Arrears}

\section{Definition:}

Expenditure arrears are defined as the difference between payment obligations due, and actual payments made. They can arise on any expenditure item, including transfers, debt service, wages, pensions, energy payments and goods and services. Expenditure arrears for goods and services to suppliers are defined as obligations to suppliers, which are due but not paid for more than 30 days and are nondisputed. Arrears between the Entity central government budgets and local government, and extrabudgetary funds are not counted towards the expenditure arrears' ceiling on the general government.

\section{Application of performance criteria:}

The ceiling on accumulation of domestic payment arrears applies to obligations of the State, the Federation, and the Republika Srpska. This criterion will apply continuously. 


\section{E. Contracting or Guaranteeing of New External Debt}

Governments will consult with the IMF before contracting or guaranteeing any new external debt.

\section{Definitions:}

- The term "debt" is defined to include all current liabilities, which are created under a contractual arrangement through the provision of value in the form of assets (including currency) or services, and which require the general government to make one or more payments in the form of assets (including currency), at some future point(s) in time to discharge principal and/or interest liabilities incurred under the contract. In effect, all instruments that share the characteristics of debt as described above (including loans, suppliers' credits and leases) will be included in the definition. The definition of general government is as described above.

- New nonconcessional external debt is defined as including all debt (as defined above) contracted or guaranteed by the general government or the $\mathrm{CBBH}$ during the program period that is not on concessional terms.

- Concessional loans are defined as those with a grant element of at least 35 percent of the value of the loan, using currency-specific discount rates based on the commercial interest rates reported by the OECD (CIRRS). The average CIRRs over the last ten years - plus a margin reflecting the repayment period (1 percent for repayment period of 15-19 years; 1.15 percent for repayment period of 20-19 years; and 1.25 percent for repayment period of 30 years or more) — will be used as discount rates for assessing the concessionality of loans of a maturity of at least 15 years. For loans with shorter maturities, the average CIRRs of the proceeding six-month period (plus a margin of 0.75 percent) will be used.

- Short-term debt is defined as debt contracted or guaranteed by the general government with an original maturity of up to and including one year.

\section{Application of performance criteria:}

The ceiling on contracting new short-term external nonconcessional debt applies to obligations of the State, the Federation, and the Republika Srpska. This criterion will apply continuously. 


\section{Data Reporting}

The Bosnia and Herzegovina authorities will report the following data to the Fund within the time limits listed below. The authorities will also provide, no later that the first week of each month, a summary of key macroeconomic policy decisions taken during the previous month; a summary of regulatory changes in the area of banking and financial sector, report any revisions to monthly and annual fiscal reports as well as any amendments to the Entity and state budget and local government budgets within a week after their approval.

Any revisions to past data previously reported to the Fund will be reported to the Fund promptly, together with a detailed explanation. The data will be provided in an electronic form.

All magnitudes subject to performance criteria or indicative targets will be reported in millions of convertible marka where the corresponding target is in convertible marka, or in millions of euro where the target is in euro.

The Bosnia and Herzegovina authorities will supply the Fund with any additional information that the Fund requests in connection with monitoring performance under the program on a timely basis.

\section{Daily Data Reporting}

The Bosnia and Herzegovina authorities will send to the Fund the following data no later than 14 working days after the end of each week:

(i) Deposits, by bank

(ii) Gross international reserves

(iii) $\mathrm{CBBH}$ foreign exchange purchases and sales

\section{Monthly Data Reporting}

The Bosnia and Herzegovina authorities will send to the Fund the following no later than 3 weeks after the end of each month:

(i) The balance sheet of the CBBH.

(ii) The commercial bank survey and monetary survey 
(iii) Banking supervision financial soundness indicators, including capital adequacy ratio, loan-loss provisioning data, nonperforming loan data.

(iv) Weighted average interest rates by bank and by type of loans

(v) Net foreign exchange position, by bank

(vi) Exposure of foreign parent bank to its subsidiary(ies) in $\mathrm{BiH}$ (amount of deposits, loans and subordinated loans from foreign parent banks).

(vii) Data on direct bank cross-border claims on BiH corporations and households (along the lines reported by the Bank for International Settlements in its Table 9C: Consolidated Banking Statistics).

(viii) Detailed information on (a) banking sector credit to the general government (by level of government), and (b) government deposits in the banking sector (Table 1).

(ix) Revenues, expenditures and financing data for central governments (the State, and the Entity governments). Expenditures will include those financed from deposits in the escrow accounts.

(x) ITA revenues.

(xi) New external loans contracted or guaranteed by governments.

(xii) New domestic loans contracted or guaranteed by governments.

(xiii) Domestic debt payments (interest, amortization) by level of government

(xiv) Report on inflows into and outflows from escrow accounts (FBiH, RS).

(xv) Transfers to the Entity Development Banks from the Entity central governments.

\section{Quarterly Data Reporting}

The Bosnia and Herzegovina authorities will send to the Fund the following quarterly data within five weeks after the end of each quarter.

(i) Banking supervision: financial soundness indicators, quarterly

(ii) Banking supervision: commercial bank's balance sheets (by bank)

(iii) Banking supervision: commercial banks' income statement (by bank) 
(iv) Revenues, expenditures and financing data for municipalities (in both entities), and cantons (in the Federation).

(v) Revenues, expenditures and financing data for the Brcko District.

(vi) Revenues, expenditures and financing data for the road funds.

(vii) Revenues, expenditures and financing data for the extrabudgetary funds (pension funds, health funds, unemployment funds and (in the RS) the children's fund).

(viii) Financial statements of (a) the RS Investment and Development Bank, and (b) Federation's Development Bank.

(iv) External debt service projections for current year; total, by creditor, by level of government, and in original currency

(x) Summary of government guarantees.

(xi) Summary of government foreign loans and degree of concessionality (grant element); total, by creditor, by purpose (project/budget support) and original currency

(xii) Summary of short-term loans by government, by creditor.

(xiii) External debt service payments (interest, amortization) by level of government

(xiv) Summary of foreign loan disbursements, by creditor, by level of government, by purpose (project/budget support) and original currency

(xv) Stock of external debt for (a) public sector; (b) private nonbank sector and (c) banking sector.

(xvi) Summary of domestic loan disbursements, by creditor, and by level of government.

(xvii) Stock of domestic debt outstanding, by level of government; and projected domestic debt service payments (interest, amortization).

(xviii) Report on project and budget support grants for general government prepared by MOF BIH Unit for coordination of international economic aid. The unit will also coordinate data flow from federation, RS and local governments. The report will include information on the country of the donor, sector of support and the purpose (project/budget/BOP, etc) 
Table 1. Bosnia and Herzegovina: Performance Criteria Under

the 2009-10 Stand-By Arrangement 1/

(In millions of KM, unless otherwise noted)

\begin{tabular}{|c|c|c|c|c|c|c|}
\hline & \multicolumn{4}{|c|}{2009} & \multicolumn{2}{|c|}{2010} \\
\hline & \multirow{2}{*}{$\begin{array}{l}\text { March } \\
\text { Actual }\end{array}$} & \multirow[t]{2}{*}{ June } & \multirow{2}{*}{\multicolumn{2}{|c|}{$\begin{array}{c}\text { September December } \\
\text { Performance criteria }\end{array}$}} & March & June \\
\hline & & & & & \multicolumn{2}{|c|}{ Indicative targets } \\
\hline \multicolumn{7}{|l|}{ Ceiling on accumulation of net credit of the banking system to: $1 /$} \\
\hline general government & -57 & 696 & 476 & 676 & 157 & 337 \\
\hline State government & -109 & -24 & 44 & 44 & 29 & 59 \\
\hline RS government & 123 & 376 & 424 & 536 & 132 & 336 \\
\hline Federation government & -58 & 346 & 15 & 108 & -3 & 46 \\
\hline \multicolumn{7}{|l|}{ Ceiling on new guarantees and the assumption of enterprise debt to banks by the } \\
\hline State, Federation and RS governments $2 /$ & 0 & 0 & 0 & 0 & 0 & 0 \\
\hline Ceiling on accumulation external payment arrears $2 /$ & 0 & 0 & 0 & 0 & 0 & 0 \\
\hline Ceiling on contracting new short-term external nonconcessional debt 2/ & 0 & 0 & 0 & 0 & 0 & 0 \\
\hline \multicolumn{7}{|l|}{ Ceiling on accumulation of domestic arrears of: $2 /$} \\
\hline State government & 0 & 0 & 0 & 0 & 0 & 0 \\
\hline RS government & 0 & 0 & 0 & 0 & 0 & 0 \\
\hline Federation government & 0 & 0 & 0 & 0 & 0 & 0 \\
\hline
\end{tabular}

1/ Cumulative within each calendar year.

2/ Continuous. 
Table 2. Bosnia and Herzegovina: Prior Actions and Structural Benchmarks, June 2009-June 2010

Implementation date

\section{Prior Actions for the approval of the arrangement}

1. Adopt rebalanced budgets by Entity governments and submit to Parliaments.

2. Adopt amendments to the wage bill legislation by the State Council of Ministers.

3. Adopt the Intervention Law in the Federation.

4. Adopt the excise law.

5. Adopt the Global Framework by the Fiscal Council

\section{Structural Benchmarks}

A. Continued adherence of the Currency Board Arrangement as constituted under the law

continuous

B. Fiscal Sector

1. Approve the rebalanced budgets by the Entity Parliaments

end-August 2009

2. Agree on an action plan acceptable to the World Bank and IMF staffs to reform the system of rights-based transfers (Federation)

3. Submit to the Parliament a Law forbidding passing of unfunded legislation (Federation)

end-November 2009

4. Publish on the State government's web site quarterly consolidated general government

end-November 2009 accounts with a 5 week lag

continuous

\section{Financial Sector}

1. Form the standing committee of financial stability (SCFS) and sign the MoU on financial stability, crisis preparedness and crisis management

2. The Deposit Insurance Agency to impose a principle of universal membership requirements, including for partially state-owned banks 


\section{Statement by the IMF Staff Representative on Bosnia and Herzegovina July 8, 2009}

1. This statement provides information that has become available since the issuance of the staff report on June 17. The new information does not alter the thrust of the staff appraisal.

2. Macroeconomic developments. High-frequency economic indicators are broadly in line with the program's baseline scenario. Industrial production has been declining in the Federation (by 10 percent during January-May 2009 compared with the same period of last year) and increasing in Republika Srpska (by 17 percent over the same period) solely due to the startup of a large refinery in late 2008. Negative trends in exports and imports continueboth declining by 23.4 percent and 25.5 percent, respectively over the same period - raising the possibility of a smaller current account deficit in 2009 compared to the program. May data point to low core inflation (1.6 percent year-on-year), while, on account of declines in food and energy prices, headline inflation has turned negative (-1 percent year-on-year).

3. $\quad$ Fiscal measures. The authorities have adopted all prior actions for Board consideration of their Stand-By Arrangement request. Besides the approval of rebalanced budgets by the Entity governments, Federation cantons also approved restrictive budgets.

4. European Bank Coordination Initiative. Following a meeting in Vienna on June 22, the parent institutions of the six largest foreign banks incorporated in Bosnia and Herzegovina signed a statement reaffirming their commitments to take action to support their subsidiaries in the country. Specifically, they committed to: (i) maintaining their exposures to their subsidiaries in Bosnia and Herzegovina; and (ii) ensuring adequate capitalization of their subsidiaries as assessed under stress tests to be conducted by the Central Bank of Bosnia and Herzegovina (CBBH). Individual commitment letters are expected to be sent to the $\mathrm{CBBH}$ in the coming weeks. 
Press Release No.09/258

FOR IMMEDIATE RELEASE

July 8, 2009
International Monetary Fund

Washington, D.C. 20431 USA

\section{IMF Executive Board Approves US\$1.57 Billion Stand-By Arrangement for Bosnia and Herzegovina}

The Executive Board of the International Monetary Fund (IMF) today approved a 36-month SDR 1.01 billion (about US \$1.57 billion) Stand-By Arrangement for Bosnia and Herzegovina to support an economic program designed by the authorities to mitigate the effects of the global financial crisis. The approval makes SDR 182.63 million (about US\$282.37 million) immediately available and the remainder in installments subject to quarterly reviews.

The authorities' program aims to safeguard the currency board, consolidate public finances and bring them on a sustainable medium-term path, maintain adequate liquidity and capitalization of banks, secure sufficient external financing, and restore confidence.

Following the Executive Board discussion on Bosnia and Herzegovina, Mr. Takatoshi Kato, Deputy Managing Director and Acting Chair, said:

"Bosnia and Herzegovina exhibited solid growth performance in recent years, largely reflecting the effects of reforms in key sectors, the benefits of the currency board, and a favorable external environment. Robust growth has been increasingly accompanied by macroeconomic imbalances, as rapid credit expansion, funded by large capital inflows, drove domestic demand past sustainable levels. The loosening of fiscal and income policies in 2008 further aggravated the overheating and left public finances vulnerable when the global financial crisis hit. Against this background, the corrective policies adopted by the authorities, along with international financial support, will contribute to realizing an orderly adjustment.

"In these circumstances, the authorities' economic and financial policies are rightly geared toward safeguarding the currency board arrangement, which has served the country well. A 
determined implementation of the fiscal income and financial sector policies is the best guarantee of the continued viability of the currency board.

“The authorities' fiscal policy strikes an appropriate balance between the near-term adjustment and the reforms to ensure medium-term sustainability. The large structural fiscal deficit, financing constraints, and the need to support the currency board mean that automatic fiscal stabilizers have limited room to operate. The containment of recurrent expenditure will create fiscal space for public investment and social spending. Better targeted social programs would help the most vulnerable groups. The authorities' determination to undertake difficult structural fiscal reforms - essential for improved effectiveness of public spending and medium-term sustainability-is welcome.

"Steps to maintain confidence in the banking system are also welcome. The program calls for enhanced monitoring of financial stability by establishing a standing committee in charge of crisis prevention and management, and by strengthening the capacity to conduct stress tests. Foreign parent banks' commitment to maintain exposures to their subsidiaries and enhance the subsidiaries' capital as needed is critical for the stability of the banking system. The authorities are also taking steps to bolster the deposit insurance framework and will need to improve bank resolution procedures.

"Given the possibility that the external economic environment may deteriorate and the challenge of implementing fiscal policies, clear communication of the authorities' policy objectives and effective public engagement on the benefits of reforms are of prime importance. The authorities' strong commitment to appropriate policies and to undertaking measures as needed to achieve the program's economic and financial objectives bode well for a successful outcome," Mr. Kato stated.

\section{Recent Economic Developments}

Benefiting from a favorable external environment, the currency board, and the effects of reforms in key sectors, growth averaged 6 percent per year during 2003-08, while inflation remained low. Bank privatizations and reforms in the financial sector, along with improved growth prospects, attracted large capital inflows. However, with capital inflows driving a domestic demand boom, internal and external imbalances worsened: growth of bank credit to the private sector rose sharply, core inflation accelerated, and the current account deficit widened. Loose fiscal and incomes policies also contributed to the overheating of the economy.

The negative fallout from the global crisis started to become increasingly evident in late 2008. Stock market indices slumped, international reserves began to decline, bank credit growth came to a halt, and financial soundness indicators started to deteriorate. With bank credit drying up, construction activity faltered, and a number of enterprises began to lay off 
workers. Revenue performance weakened, while expenditure, driven by increases in wages and social benefits, rose sharply. As a result, the general government deficit widened to 4 percent of GDP from a near-balance in 2007.

\section{Program Summary}

The authorities' economic program is designed to safeguard the currency board and cushion the effects of the deteriorating external environment, while adopting policies to redress fiscal imbalances and strengthen the financial sector. The program should help position the country's economy for a strong recovery once the global economic environment improves, and, in the medium-term, help set the stage for sustainable growth and convergence with the European Union by providing a framework for structural reforms to strengthen the economy's supply side, and safeguard competitiveness.

The specific objectives of the program are to:

- Reduce the structural fiscal balance to limit the government's financing needs and bring public finances on a sustainable medium-term path;

- Reestablish public wage restraint;

- Support adequate liquidity and capitalization of banks; and

- Secure sufficient external financing and improve confidence.

Bosnia and Herzegovina joined the IMF on December 14, 1992, and its quota is SDR 169.10 million (about US\$261.45 million). Its latest arrangement with the IMF was a Stand-By Arrangement that expired on February 29, 2004. 
Bosnia and Herzegovina: Selected Economic Indicators, 2005-09

\begin{tabular}{|c|c|c|c|c|c|}
\hline & 2005 & 2006 & 2007 & $\begin{array}{c}2008 \\
\text { Est. }\end{array}$ & $\begin{array}{r}2009 \\
\text { Proj. }\end{array}$ \\
\hline & \multicolumn{5}{|c|}{ (Percent change) } \\
\hline Real GDP & 3.9 & 6.9 & 6.8 & 5.5 & -3.0 \\
\hline CPI (period average) $1 /$ & 3.6 & 6.1 & 1.5 & 7.4 & 1.6 \\
\hline \multicolumn{6}{|l|}{ Money and credit (end of period) } \\
\hline Broad money & 18.2 & 24.7 & 21.6 & 4.3 & 0.6 \\
\hline Credit to economy & 27.5 & $\begin{array}{l}23.3 \\
\text { (In pe }\end{array}$ & $\begin{array}{r}28.1 \\
\text { ent of } G\end{array}$ & 20.8 & 0.0 \\
\hline \multicolumn{6}{|l|}{ General government budget } \\
\hline Revenue & 45.5 & 47.4 & 47.4 & 45.8 & 45.0 \\
\hline Expenditure (on a commitment basis) & 44.7 & 45.2 & 47.5 & 49.9 & 49.7 \\
\hline Overall balance & 0.8 & 2.2 & -0.1 & -4.0 & -4.7 \\
\hline External public debt & 25.6 & 21.2 & 18.3 & 17.1 & 21.5 \\
\hline NPV of external public debt & 19.6 & 16.2 & 14.0 & 13.0 & 16.5 \\
\hline Total public debt & 25.6 & \multicolumn{3}{|c|}{ (In millions of euros) } & 34.7 \\
\hline \multicolumn{6}{|l|}{ Balance of payments } \\
\hline Exports of goods and services & 2,832 & 3,589 & 4,062 & 4,580 & 3,843 \\
\hline Imports of goods and services & 6,393 & 6,493 & 7,656 & 8,688 & 7,050 \\
\hline Current account balance & $-1,555$ & -816 & $-1,401$ & $-1,842$ & $-1,201$ \\
\hline (In percent of GDP) & -18.0 & -8.4 & -12.7 & -14.7 & -9.7 \\
\hline Gross official reserves & 2,145 & 2,761 & 3,425 & 3,219 & 2,932 \\
\hline (In months of imports) & 4.0 & 4.3 & 4.7 & 5.5 & 4.7 \\
\hline External debt service & 267 & 412 & 326 & 364 & 433 \\
\hline (In percent of exports of goods and services) & 9.4 & 11.5 & 8.0 & 8.0 & 11.3 \\
\hline Exchange rate regime & \multicolumn{5}{|c|}{ Currency board since August 1997} \\
\hline Exchange rate, July 8, 2009 & \multicolumn{5}{|c|}{$1 \mathrm{KM}=$ Euro 0.5113} \\
\hline Real effective exchange rate $(2000=100$, increase $=$ appreciation $) 2 /$ & 87.8 & 89.8 & 88.2 & 90.1 & \\
\hline
\end{tabular}

Sources: Bosnian authorities; and IMF staff estimates and projections.

$1 /$ In 2006, affected by the VAT introduction.

2/ Adjusted for VAT effects. 


\section{Statement by Age Bakker, Executive Director for Bosnia and Herzegovina And Miroslav Tomic, Advisor to Executive Director July 8, 2009}

\section{Introduction}

The economy of Bosnia and Herzegovina $(\mathrm{BiH})$ did not escape the impact of the global crisis. After several years of strong growth, supported by foreign investments and capital inflows and reflected in an increase in employment, the deterioration in the external environment and increase in domestic imbalances, threaten to challenge these achievements. The global crisis put the spotlight on the good policies done in the past (e.g. direct tax reform, establishment of a national fiscal council), but, more importantly, exposed the consequences of the unfinished agenda (public wage bill, reform of social sector rights-based untargeted benefits). In order to minimize the negative consequences and further strengthen economic development potential, the authorities have prepared strong adjustment measures explained in the Letter of Intent. Required prior actions have been met with wide margins, signaling strong determination to implement further measures.

\section{Macroeconomic update: from the threat of overheating to reduced activities}

The year 2008 saw transition from overheating-increase in (CPI) inflation to 7.4\% from $1.5 \%$, widening current account deficit by $2 \%$ of GDP to $14.7 \%$, credit growth by $30 \%$ etc., to deposit withdrawal, credit tightening, interest rate increase, export reduction, unemployment increase, and threats to financial stability. Although the annual growth rate estimated at 5.5\% still was satisfactory, revenue growth slowed in Q4 and, together with increase in public wages that occurred in the first part of the year, contributed to the widening fiscal deficit to a record high. For the first time after several years the primary balance turned into deficit.

The fiscal deterioration manifested asymmetrically in the two entities: while successful privatization of RS Telekom provides a cushion and allowes a development-related spending stimulus, the Federation BiH's central government budget, burdened with unfunded war related social entitlements, ended last year with expenditure arrears. In addition, the privatized oil refinery commenced with production in November 2009, contributing to growth in industrial production in the Republika Srpska (RS), while the privatization process in the Federation $\mathrm{BiH}$ was stalled.

\section{Financial and external sector: impact of the crisis}

The financial sector so far weathered the impact of the financial crisis relatively well. At the beginning of 2008, in order to limit credit growth that contributed to the overheating, the Central Bank of $\mathrm{BiH}(\mathrm{CBBH})$ increased reserve requirements from $15 \%$ to $18 \%$. At the first sign of increased deposit withdrawals, the CBBH promptly relaxed reserve requirements strengthening the liquidity position of the banks. The reserve 
requirement was decreased in stages closely monitoring bank activities and the relationship with mother banks. In order to allow branches to have cheaper access to mother banks, new capital was exempt from reserve requirements. To strengthen the deposit security, the authorities increased deposit insurance from $7500 \mathrm{KM}$ to $20000 \mathrm{KM}$. Financial soundness indicators did deteriorate, but still remain far above the regulatory requirement. The situation stabilized with the effect that $11 \%$ of deposits was withdrawn and foreign exchange reserves were reduced by $16 \%$ from their peak level in 2008 . Despite the increase in wages and relatively high recorded CPI inflation, there is no evidence of an overvaluation of the $\mathrm{BiH}$ currency. Although the share of $\mathrm{BiH}$ exports to the EU has been growing, the authorities are closely monitoring the real effective exchange rate behavior, particularly in light of the depreciation by some countries in the region, and stand ready for corrective measures in the wage policy.

\section{Outlook: 2009 and beyond}

Confronted with reduced revenues, the authorities at all levels limited non-mandatory expenditures in Q1 2009. While inflation pressures have abated and although the external position is expected to improve due to a faster drop in imports compared to exports, the sluggish recovery in major trading partners leaves no room for complacency. With a projected sharp fall in the GDP growth rate of 3\% and an expected fall in revenue collection that could exceed $10 \%$, the authorities are aware that a more serious effort, including external support, is needed.

\section{SBA program: crisis as an incentive}

The program is designed to preserve confidence in policy making, and particularly the currency board arrangement, a backbone of macroeconomic stability. The proposed duration of program (36 months) is based on the awareness that implementation of structural reforms is time consuming and complex and that results may come only with the lag. The authorities believe that the interest of the country would be better served by close cooperation with international financial institutions, as envisaged under the SBA, over a longer rather than shorter time period. This is not only because of the financing provided, but, more importantly, because of the guidance on and conditionality of the adjustments. The sheer process of the program negotiations contributed to an improvement in intergovernmental fiscal policy coordination through the National fiscal council (NFC), as all levels of government accepted to share the burden of adjustment.

Fiscal sector: immediate adjustment and structural improvements At the outset, it should be stressed that the adjustment under the program is frontloaded, exceeding $3.1 \%$ of the GDP already in 2009, with the bulk of measures on the expenditure side. The reduction in expenditures on wages, allowances, transfers, etc. could be challenged and has been challenged from different perspectives, including social sensitivity and goals of macroeconomic stabilization. 
On the one hand, while a reduction in public expenditures when both domestic and external demand is shrinking, could appear as pro-cyclical and counterproductive, the financing limitations and composition of the reduction reveals a different story. First, borrowing by the public sector from commercial banks, which the Federation $\mathrm{BiH}$ government was forced to do in order to cover 2008 arrears, would further limit availability and increase the cost of borrowing for the private sector. Second, a reduction in public wages, apart from its contribution to the fiscal balance, will have a positive effect on competitiveness and is supportive of the currency board arrangement. Third, immediate savings in non-targeted benefits for war veterans and civil victims, and initiation of the (long overdue) revision process under the auspices and guidance of the World Bank are expected to strengthen the structural fiscal balance that will positively reflect in the country's credit rating.

On the other hand, one could argue that the adjustment is insufficient. Attempts to further reduce expenditures in the current juncture may, however, be politically unfeasible. In a nutshell, non-reduction in public expenditures when multiplier effects are unknown and financing is either expensive or nonexistent, will certainly decrease the quality of the public finances. Insistence on additional reductions could well be impossible for political economy reasons and therefore jeopardize the tangible improvements expected under the proposed SBA. The measures under the program, such as introduction of means-testing for all civilian and war related benefits, revisions of existing legislation granting the entitlements, and adoption of the fiscal responsibility law, beyond any doubt will strengthen the structural fiscal balance. On the revenue side, the adoption of the excise law (a prior action) is not only expected to increase the revenue but is also a step forward in harmonizing the tax legislation with that of the EU. The enactment of this law was also a precondition for the EBRD highway construction project loan, a major and longawaited capital investment.

Financial sector: expected improvements under the SBA

The financial sector is dominated by the banking sector, characterized by a huge share of foreign capital.Most banks operating in $\mathrm{BiH}$ are subsidiaries of mother banks from Austria, Italy and Slovenia. Foreign banks operating in $\mathrm{BiH}$ pledged their continued presence and exposure at a meeting chaired by the IMF in Vienna on June 22, 2009. The SBA is envisaging further institutional improvements in monitoring and crisis preparedness. The authorities will, as part of financial sector strengthening under the SBA, establish a Standing Committee for Financial Stability (SCFS) consisting of the $\mathrm{CBBH}$, entity banking supervision agencies, and the Deposit insurance agency (DIA). Cooperation under the umbrella of the SCFS will secure more efficient collection of high-frequency data and also raise awareness of the interdependences of policy decision in different sectors through timely dissemination of financial sector data and reports. Based on recent MCM technical assistance recommendations, among other things a contingency manual for a bank resolution strategy will be prepared, while amendments to 
the law increasing banking supervision agency discretion in appointing temporary administrators will be enacted. DIA membership principles will be harmonized with banking licensing, allowing universal membership in DIA (currently possible only if the bank is at least in $90 \%$ private ownership). Finally, the authorities will use a credit line from the EBRD (50 million Euros, final approval expected on July 14, 2009), to further increase deposit guarantees to $50000 \mathrm{KM}$. Given that the SCFS is modeled on successful intergovernmental cooperation within the NFC, it is expected to contribute to financial sector stability. A strong currency board arrangement and privatization of the banking system are considered the most successful reforms in the post-war period. The authorities are aware of the importance of the stability of the financial sector, will refrain from any unilateral decision and stand ready to consult with the Fund if further actions are required during the program.

\section{Statistics}

The program will bring additional quality to macroeconomic management through the harmonization in relevant macroeconomic data as the entities and the state agency will harmonize expenditure and production GDP. The precondition for successful monitoring, not only of the program targets but also of NFC targets, requires improvements in reporting metodology and frequency of fiscal data availability. The authorities look forward to technical assistance in this area.

\section{Conclusion}

The authorities learned the lesson of the importance of structural reforms during good times through the financial squeeze in bad times. The proposed program is an optimal combination of what should and can be done in order to secure the currency board arrangement and stability of the financial sector. The program strikes a feasible balance between the need to keep public debt at a comfortable level, while it improves the quality of public expenditure, through improved targeting in the social sector and infrastructure spending. The relationship with the Fund and other international institutions will help focus the policy effort in a direction beneficial for economic development and the EuroAtlantic integration process.

More than a courtesy

Finally, the authorities would like to express sincere gratitude to the IMF staff headed by Head of Mission Mr. Christou for the beneficial, useful and fruitful discussion, including occasional disagreements and misunderstandings, and look forward to continued cooperation. 